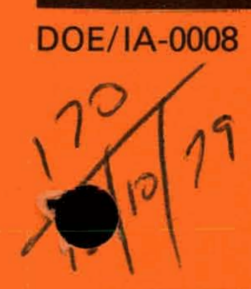

Prepared jointly by the

U.S. Department of Energy \& U.S. Geological Survey

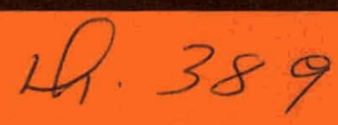

\title{
MASTER
}

\section{Report on the \\ Petroleum Resources of the Federal Republic of Nigeria}

Foreign Energy Supply Assessment Program Series

October 1979

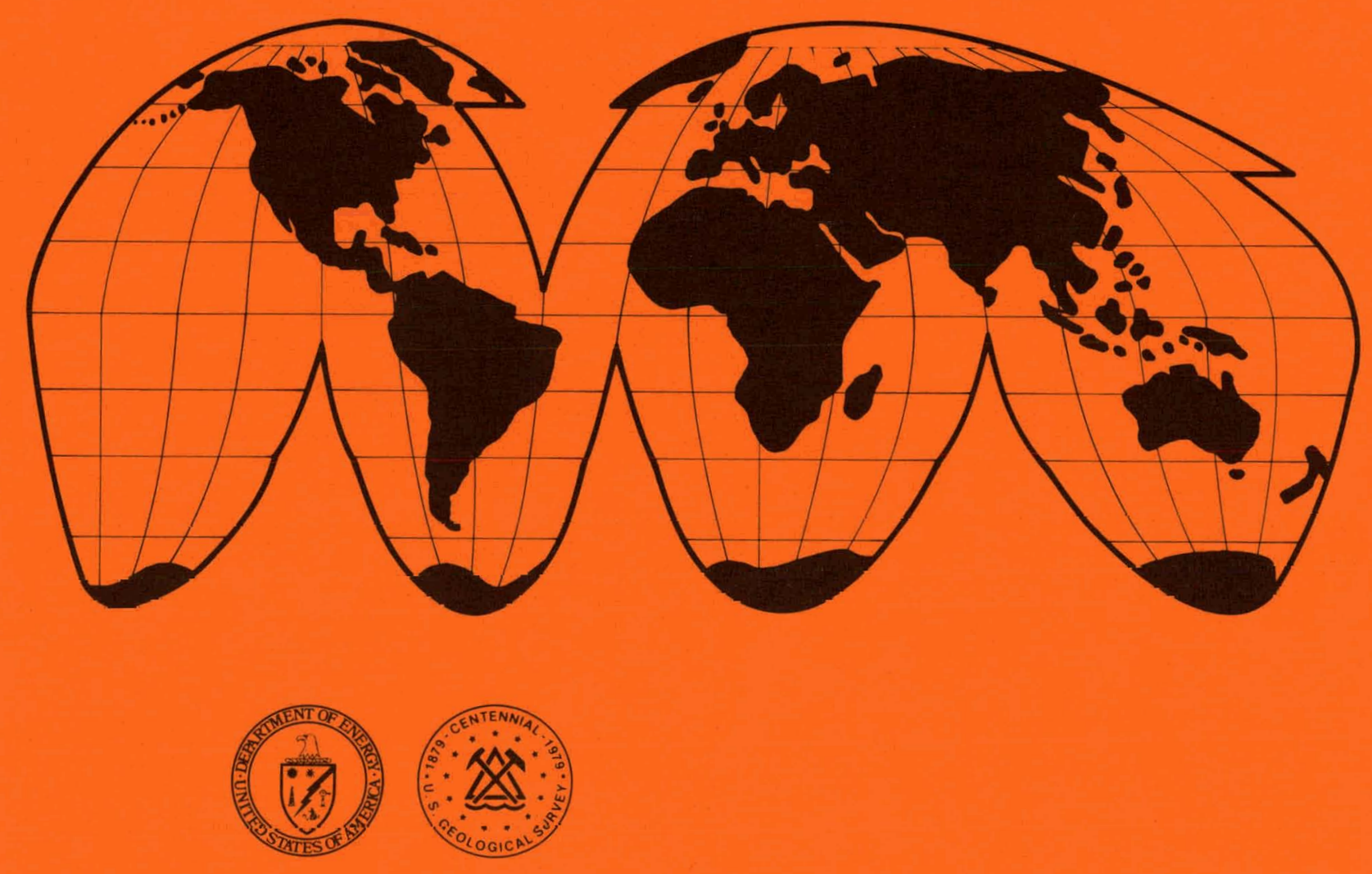




\section{DISCLAIMER}

This report was prepared as an account of work sponsored by an agency of the United States Government. Neither the United States Government nor any agency Thereof, nor any of their employees, makes any warranty, express or implied, or assumes any legal liability or responsibility for the accuracy, completeness, or usefulness of any information, apparatus, product, or process disclosed, or represents that its use would not infringe privately owned rights. Reference herein to any specific commercial product, process, or service by trade name, trademark, manufacturer, or otherwise does not necessarily constitute or imply its endorsement, recommendation, or favoring by the United States Government or any agency thereof. The views and opinions of authors expressed herein do not necessarily state or reflect those of the United States Government or any agency thereof. 


\section{DISCLAIMER}

Portions of this document may be illegible in electronic image products. Images are produced from the best available original document. 
Available from:

Nationa1 Technical Infarmation Service (NTIS)

U.S. Department of Commerce

5285 Port Royal Road

Springfield, Virginia 22161

Price: Printed copy:

Microfiche:

$\$ 3.00$ 


\title{
Report on the
}

Petroleum Resources of

the Federal Republic

of Nigeria

\section{Foreign Energy Supply Assessment Program Series}

\section{October 1979}

The participating offices include:

\author{
Department of Energy \\ International Affairs \\ Energy Information Administration \\ Policy and Evaluation \\ Resource Application \\ U.S. Geological Survey \\ Energy Resources Division \\ Resource Appraisal Group
}

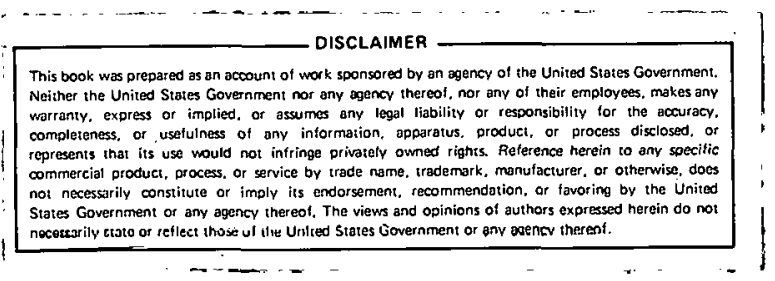


FOREWORD

This study of Nigerian oil and natural gas resources is the first of a proposed series of studies under the Foreign Energy Supply Assessment Program of the Department of Energy. Future studies will examine the petroleum resources of other world political entities, with a view to estimating the future availability of crude oil and natural gas.

Obviously, the economic and political decisions of oil and gas producing states, and those states which have potentially exploitable resources, will determine the rate at which oil and gas will be produced. The latitude of such decisions, however, will be constrained by the physical limits of ultimately recoverable resources, and it is this latter dimension which these studies will attempt to measure.

There is no question that the supply of fossil fuel resources is limited. Thus, it is essential, from both a producer and from a consumer perspective, that these limits be defined as accurately as possible. With this knowledge in hand, it will then become possible to plan more intelligently for our energy future. 
TABLE OF CONTENTS

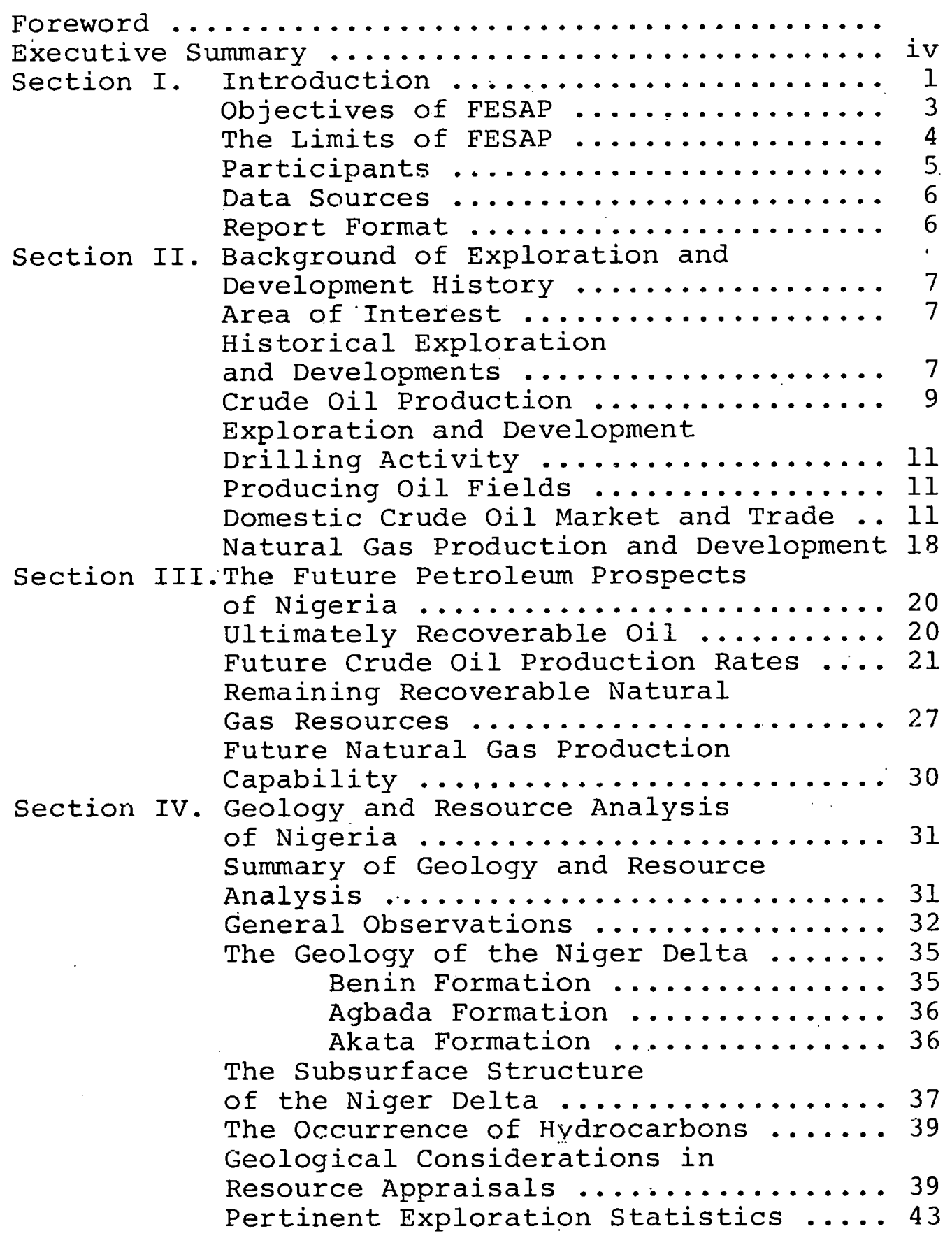


Resource Appraisal by Analysis of Finding-Rates ................ 45 Basic Statistical Data for the Niger Delta ................ 50 Resource Appraisal by Geological Analysis .............. 51 Estimates of Remaining Oil Resources Using Various Methods ............. 53 Volumetric "Yield" by Province ... 53 Volumetric "Y.ield" by Productive Hydrocarbon Belts ..... 53 Grid-average Method ........... 54

Final Resource Appraisal for Oil Using Subjective Probability Methods ... 54 Resource Appraisals for Natural Gas ... 57 Es cimates of Oil Field Sizes and Nimbers for Remaining Undiscovered

Appendices Resources ...................6 60

\section{FIGURES}

Figure II-1 Nigeria Location Map with Population Centers .............. 8

Figure III-1 Sensitivity of Maximum Production Capability profiles .............. 22

Figure III-2 Maximum Production Capability Profiles Using Mean Ultimate Recovery ........23

Figure III-3 Historical and Projected Production Profiles Based Upon the Mean Ultimate Recovery ............... 24

Figure III-4 Historical and Projected Crude Oil Production for Five Ultimate

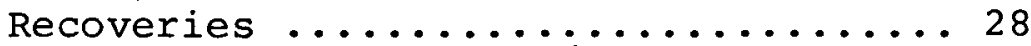

Figure IV-1. General Geological Map of the Niger Delta and Environs .......... 33

Figure IV-2 . Formations of the Niger Delta Area, Nigeria ................... 34

Figure IV-3 Different Evolutional stages of the

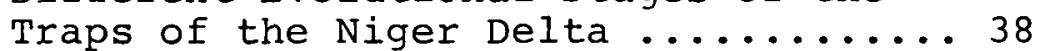

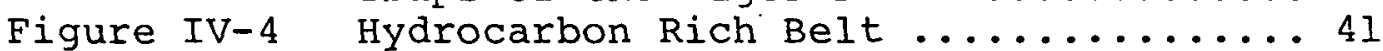
Figure IV-5. Historical Oil Field Size Distribution 46 Figure IV-6 Historic and Projected Oil Finding-Rates for Nigeria .........448 


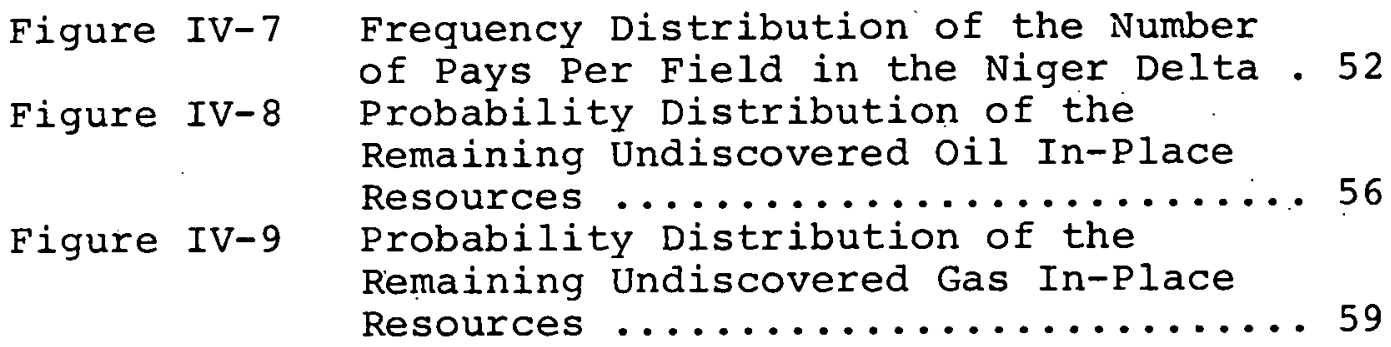

TABLES

Table II-1 Crude Oil Production History of Nigeria 10

Table II-2 Nigeria Historic Drilling Record ..... 12

Table II-3 Historical Peak production of Nigerian Oil Fields .............. 13

Table II-4 The Major Oil Fields of Nigeria ...... 15

Table II-5 The Number of Producing Oil Fields

Identified by Year of Discovery and

Their Cumulative Production ......... 16

Table II-6 Nigeria's Crude Oil Exports, 1972-1977. 18

Table II-7 Nigeria's Crude Oil Export Markets: $1977 \ldots \ldots \ldots \ldots \ldots \ldots \ldots$

Table III-1 Alternative Production Schedules

for Nigeria .................. 26

Table IV-1. Exploratory Footage Drilled in Nigeria. 44

Table IV-2 Probability Levels Remaining Undiscovered oil ................. 55

Table IV-3 Probability Levels Remaining Undiscovered Gas ................ 58

Table IV-4 Resource Estimates Disaggregated by Future Field Size Range and Number .... 60

Table IV-5 Disaggregated Field Sizes .......... 61

Table IV-6 Estimated Number of Small and and Intermediate Size Fields ........6 61

Talbe IV-7 Estimated Number of Large Fields ..... 62 


\section{EXECUTIVE SUMMARY}

The Republic of Nigeria ranks among the ten largest oil producers of the world. Production during the first part of 1979 was as high as 2.4 million barrels per day. It is also one of the leading exporters of crude oil: All but three to four percent of Nigerian production is exported; the rest is used for domestic consumption.

Several of Nigeria's African neighbors are critically dependent on her oil exports. However, well over half of the exported oil is sold to the United States and to The Netherlands. Although the U.S. share of Nigerian exports is equivalent to only three to four percent of U.S. demand, the Nigerian crude is important because of its low sulfur quality and high gasoline yield. This crude characteristic makes it desirable also to The Netherlands's refineries, which re-export refined products to Western European markets.

Based on geological and engineering analyses, it is the opinion of the ad-hoc Foreign Energy supply Assessment Program (FESAP) Task Force that Nigeria's ultimately recoverable oil resources may range from 20.5 to 41.5 billion barrels. Through 1977, 6.1 billion barrels had been produced; thus, the remaining recoverable oil ranges from 14.4 to 35.4 billion barrels. About 18.7 billion barrels have been discovered; from 1.8 to 22.8 billion barrels remain to be discovered. There is a 95 percent probability that at least 1.8 billion barrels remaing to be discovered, and only a 5 percent probability that at least 22.8 billion barrels will be found. The mean value (which is a statistical average) of undiscovered recoverable oil is 8.4 billion barrels, and has a 38 percent probability of occurrence.

It is possible, with an accelerated exploration and development effort, that Nigeria's production capability could reach a peak level of 3.3 million barrels per day, or a constant production plateau of about 3.0 million barrels per day. This is based on estimates of 
ultimate recoverable resources of 27.1 billion barrels and the assumption that production would be constrained only by geological factors. The period of production at this level would be brief, approximately five years. Lower constant production plateaus, however, which reflect slower rates of exploration and development, are more likely. Production plateaus greater than 2.0 million and less than 2.5 million barrels per day could be maintained for more than a decade, and such rates would defer significant depletion of Nigeria's ultimately recoverable oil resources through the 20 th century.

Nigeria's exploration began early in this century, although the modern exploration phase began in 1955 . Exploration and development may have peaked quickly, as 13 of 14 known, probable and possible giant oil fields were discovered prior to 1969, and the greatest number of fields were discovered in the period 1965. through 1967. Over two-thirds of the ultimately recoverable oil of Nigeria has been discovered.

of the known producing fields, more than twothirds have or had sustainable peak production rates (production for three successive years at a specified rate) of less than five million barrels of oil per year; nearly one-half of the fields produced less than three million barrels per year. Only sixteen fields have produced at peak rates ranging from 15 to 45 million barrels per year. In essence, most of Nigeria's oil fields are small to medium size fields by world standards. Future oil discoveries are likely to reflect this trend, even though several more giants may be found.

The natural gas resources of Nigeria, unlike the oil resources, are comparatively underdeveloped. Nevertheless, sufficient exploration has taken place to permit an assessment to be made of the potential natural gas resource base.

The statistical mean estimate of undiscovered natural gas indicates that there are 65 trillion cubic feet (Tcf) of recoverable natural gas awaiting discovery. It is 95 percent probable that as little as 26 Tcf of additional recoverable gas may be discovered and it is 
five percent probable that as much as 130 Tcf of additional new gas discoveries may be found. Based on estimates that current proved reserves of natural gas are approximately 50 Tcf, Nigeria's ultimately recoverable natural gas resources may be in excess of 100 Tcf. The Niger Delta, seaward from the central portion, may be the most prospective for finding new natural gas resources.

Nigeria consumes about two to three percent, or less than 20 billion cubic feet, of its annual production of natural gas. The remainder of the natural gas that is produced along with crude oil, associated gas, is flared; approximately three-quarters of a trillion $\left(10^{12}\right)$ cubic feet.

In summary, Nigeria has the capability to increase oil production above its maximum historic level, assuming more wells are drilled, and additional surface facilities are installed. However, it is likely that the yearly average production rate will range from 2 million barrels to 2.5 million barrels per day over the next 10 years or longer. In contrast, Nigeria's natural gas resources are underdeveloped and underutilized; a situation which is common among many oil producing countries of the world. 


\section{SECTION I}

\section{Introduction}

Petroleum* is the base load enerqy source of the world. It satisfies nearly two-thirds of the world's energy needs, with crude oil alone providing one-half of that energy. In an effort to reduce the dominance of crude oil in the world energy balance, most industrialized countries, through conservation and fuel substitution programs, have had nominal success in decreasing their consumption of oil. Nevertheless, except for several recession years, the demand for oil has continued to increase, albeit at a slower rate than it did prior to 1974. In addition, a greater number of developing countries are competing for oil in the marketplace. Moreover, several of the producer nations have become greater consumers of crude oil products.

Crude oil producers, and particularly the exporting nations, are determined to control the rate at which their remaining petroleum resources are depleted. By deferring development, limiting exports, and raising prices, the producer nations are able to maintain the foreign exchange earnings necessary to achieve their respective economic and social goals. One of their stated objectives is to encourage, through pricing policies, the industrial nations to develop alternative fuel forms, and thereby slow the rate at which their finite resources are depleted.

The consideration of producer country's economic goals as the criteria for determining respective production rates and exports is the antithesis of the historic relationship of supply and demand. Historically, demand was unconstrained as supply responded to buyers' needs. During the 1970's, constraints have been placed on supply availability. The departure from the traditional supply/ demand relationship and the shift in the control of oil supplies, from the principally western oil companies to national governments, have created a great deal of uncertainty among the consuming nations as to the future availability and prices of crude oil.

* "Petroleum" in this report includes crude oil, natural gas liquids and natural gas. 
The uncertainty in the future market can be somewhat minimized if an insight can be developed as to:

- the quantities of discovered and undiscovered recoverable petroleum resources remaining among the respective producers, and the feasible rates at which such resources can be developed and produced;

- the overall capital requirements of the oil exporting countries necessary to achieve their respective social, economic and political goals, and the oil and natural gas resource development necessary to sustain the production and exports essential for maintaining foreign earnings; and finally,

- the events or political interests which might cause development, production rates, and exports to digress upward or downward from the "normal" rate consistent with goal achievement.

of the points cited above, the most fundamental concern facing the petroleum exporting nations is the physical limits of the recoverable petroleum resource base. Each country has its own finite limit of crude oil and natural gas. If the export of petroleum is critical to its economy, success in achieving economic, social, and political goals will depend on the size of its recoverable resource base and the capability to produce and export petroleum.

The Foreign Energy Supply Assessment Program (FESAP) is the government's first systematic effort to determine the quantities of conventional petroleuml/ remaining and recoverable within each country of the world.

1/ Conventional petroleum includes crude oil and natural gas recoverable by drilling, but excludes crude oil recoverable by the use of tertiary recovery methods, or from deposits of tar.sands and shales and natural gas associated with coal and geopressured water zones, etc. 
This study incorporates geological and engineering analyses with statistical techniques to estimate the remaining undiscovered recoverable resources and to determine the rate at which such resources may be produced.

The Nigerian report is the first of a series of FESAP country reports. The methodology and assumptions used herein are described in the text or in the appropriate appendices.

The estimates represent the views of the ad hoc study team consisting of Department of Energy and the U.S. Geological Survey (Department of the Interior) personnel, and should not be regarded as an official Department of Energy or Interior position.

\section{Objectives of FESAP}

The initial objective of the FESAP is to assess the quantity of recoverable crude oil and natural gas resources, including the undiscovered recoverable resources, remaining within the petroleum exporting. countries and the potential rate at which such resources can be produced.

Petroleum resource assessments provide a basis for determining a maximum production rate and the duration petroleum may be available to world markets. Nevertheless, in the short-term, the most likely rate may be a function of capital requirements of the exporting country and the importance of petroleum exports in satisfying those requirements.

Nigeria was selected as the first country study because it has a comparatively homogenous geological environment for the occurrence of petroleum and it is fairly well explored and developed.

The objectives of the FESAP country series are. achieved in the following manner:

-- An assessment is made of the reported proved reserves $2 /$ and the historical production rates;

2/ Definitions of Reserves and Resources as well as a geological time and age chart is included in Appendix $E$. 
--- A geological analysis is made of the country's sedimentary basin(s) and geological structures, which produce or have the potential to produce economic quantities of petroleum;

-- An estimate is made of the remaining undiscovered oil and natural gas in-place, the undiscovered recoverable petroleum resources, and the number of fields to be discovered;

--- A maximum production capability profile is determined using the total resource base; and

-- Feasible production rates are projected for a period until the known proved reserves and the estimated remaining undiscovered recoverable resources near depletion.

The Limits of FESAP

The FESAP analytical process is not a reservoir engineering study. However, a sufficient number of geological and engineering parameters are known to permit reasonable estimates to be made of the original oil inplace and the remaining proved reserves of many fields. Also, the use of field-analogs permits judgments to be made in instances when minimal information is available.

It is acknowledged. that national political, social and economic goals may influence exploration and development rates, thus compounding the difficulties of estimating future production rates. However, the FESAP projections of future production rates are based on the continuation of exploration and development, and on the perceived reservoir production capabilities, constrained only by geological factors:

FESAP does not overlay non-engineering parameters on the production factors, such as an economic decision, which might result in slowing the rate of exploration and development, or reducing the optimum production of wells. 


\section{Participants}

The FESAP series is a product of cooperation between geologists, engineers, statisticians and mathematicians, and other skills in the Departments of Energy and of the Interior. The principals involved in preparing the Nigerian report are:

Department of Energy:

International Affairs-

Arthur J. Warner, FESAP Program Manager

Judith Reynolds, Assistant

Energy Information Administration-

Calvin Kilgore, Director, International Data Analysis

W. D. Dietzman, Supervisory Petroleum Engineer

Henry Weigel, Operations Research Analyst John Wood, Petroleum Engineer

Velton Funk, Petroleum Engineer

Lulli Crump, Mineral Specialist

Policy and Evaluation-

Phyllis Kline, Policy Analyst

Department of the Interior, U.S. Geological Survey:

Office of Energy Resources-

Oswald Girard, Petroleum Geologist

Harold Krivoy, Physical scientist

Resource Appraisal Group-

Betty Miller, Program Chief, International Resource Appraisal

Kurt Carlson, Mathematical Geologist

Russell Allen, Geologist

Lynn Sears, Librarian 
Data Sources

The data used in preparing the analysis comes from a variety of public sources including the commercial information services of Petroconsultants, S.A. A complete list of references is provided in the bibliography.

Report Format

The report is divided into four sections and five appendices:

$\begin{array}{ll}\text { Section I } & \begin{array}{l}\text { Introduction } \\ \text { Background of Exploration } \\ \text { and Development History } \\ \text { The Future Petroleum }\end{array} \\ \text { Section III } & \begin{array}{l}\text { Prospects of Nigeria } \\ \text { Geology and Resource } \\ \text { Analysis of Nigeria }\end{array} \\ \text { Appendix A } & \begin{array}{l}\text { Analysis Report: Nigeria - } \\ \text { An Assessment of Crude Oil } \\ \text { Potential }\end{array} \\ \text { Appendix B } & \begin{array}{l}\text { Petroleum Geology of the } \\ \text { Niger Delta } \\ \text { Geologic Time Scale; } \\ \text { Definitions; References } \\ \text { Appendix C }\end{array} \\ \text { Appendix D } & \begin{array}{l}\text { Resume of Oil Field Production } \\ \text { Antical Data - Historical }\end{array}\end{array}$


SECTION II

Background of Exploration and Development History

\section{Area of Interest}

The Republic of Nigeria is located north of the central portion of the west coast of Africa. Its areal size is nearly 356.4 thousand square miles (923 thousand square kilometers) located mostly between $4^{\circ} \mathrm{N}$ to $13^{\circ} \mathrm{N}$ latitude and $3^{\circ} \mathrm{E}$ to $14^{\circ} \mathrm{E}$ longitude. The Niger Delta is the principal petroleum province of Nigeria, and the area of interest in this study. The Delta comprises some 41 thousand square miles (106 thousand square kilometers). Other areas of interest include the conterminous offshore portion of the Delta, approximately 33 thousand square miles ( 85 thousand square kilometers), and the sedimentary basins along the Niger and Benue Rivers. Figure II-l shows the Niger Delta area and the important population centers. Nigeria's population is nearly 67 million people.

\section{Historical Exploration and Developments}

The search for oil in Nigeria began during the period 1908 to 1914, when a German company, the Nigerian Bitumen Company, drilled 14 wells in the coastal regions, 55 miles east of Lagos. The drill sites were selected on the basis of surface seeps of oil which occurred along Cretaceous rock outcrops. No significant quantities of oil were found.

A hiatus followed until the late thirties, when the Shell-D'Arcy Petroleum Development Company began surface mapping, seismic and gravity surveys, and a coring program in and south of the Benue Valley, where geological structures are mappable on outcrops of Cretaceous age. The work was discontinued during World War II.

A third period of exploration began in 1947, with an extensive geological field survey and aerial photography campaign. The exploration program also used gravimetric and seismic surveys throughout Nigeria to identify the oil prospective geological structures. Most of the 


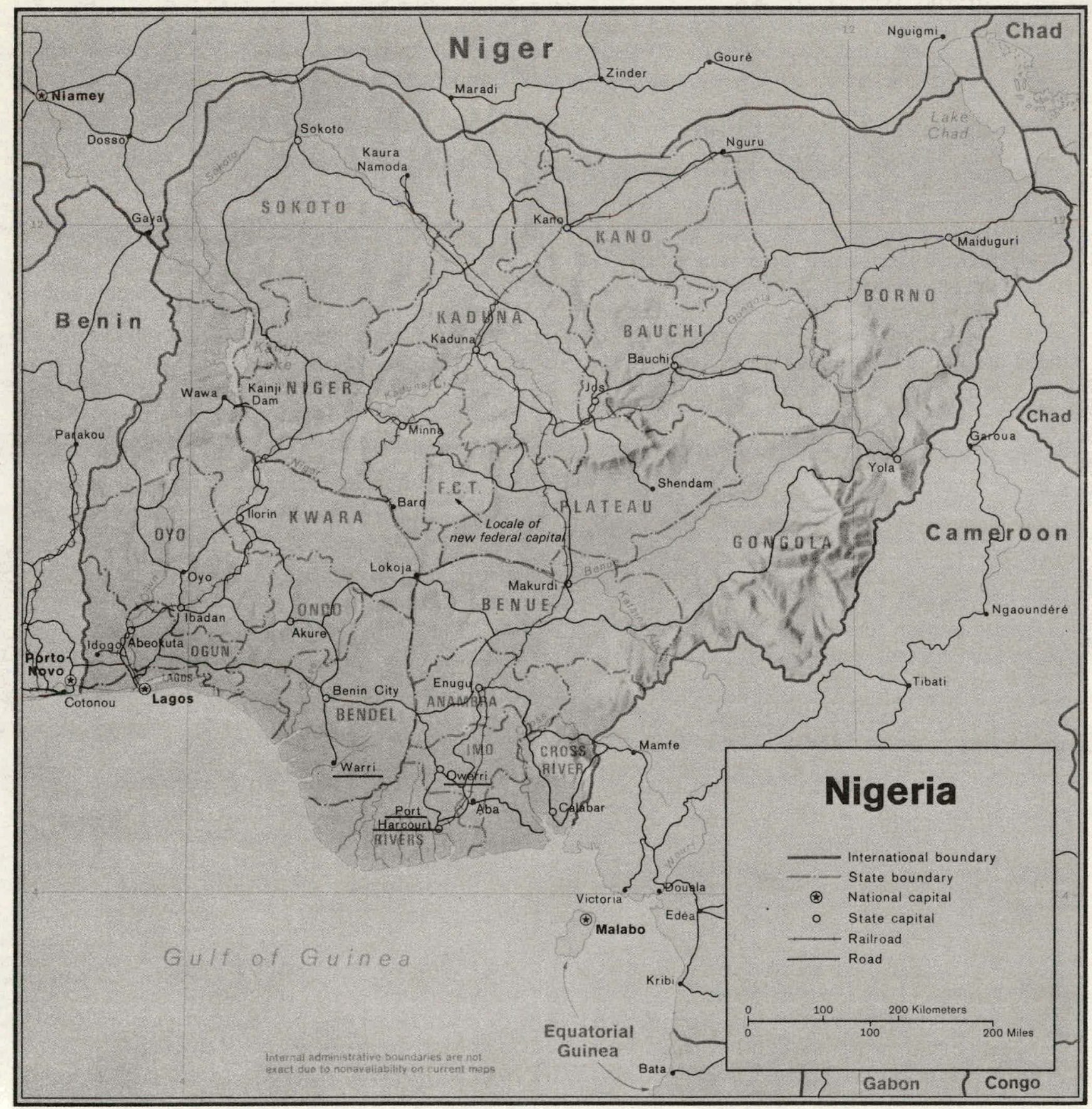

Base 503590 12-77

Figure II-I. 
drilling which followed took place in the northern part of the Delta and in the Cross River Valley on Cretaceous and Eocene prospects. In 1951 the first deep well was drilled to 11,228 feet. It was dry.

The first commercial discovery of oil was made in 1956, south of the earlier plays, approximately 75 kilometers west of Port Harcourt. The Oloibiri field discovery well was completed in a formation of Tertiary age, a much younger formation than the earlier Cretaceous targets. Although the Oloibiri field was a disappointment, as it never produced in excess of 2 million barrels in any year, it proved the existence of commercial accumulation of oil. A second field was discovered during the same year at Afam, approximately 30 kilometers northeast of Port Harcourt; it produced nearly 4 million barrels per year for several years. In 1958, the first giant oil field, Bomu, located $75 \mathrm{kilometers} \mathrm{southeast} \mathrm{of} \mathrm{Port}$ Harcourt, was discovered. The Bomu field produces over 20 million barrels per year and ultimately it could yield over 500 million barrels of oil. The first offshore giant field, Okan, was discovered in 1964, on the northeast edge of the Nigerian continental shelf.

Since the first commercial discovery of oil in Nigeria, over 200 oil and natural gas fields have been discovered.

\section{Crude Oil Production}

Nigerian oil production began in 1958. In over two decades, oil production has increased to a rate in excess of 2 million barrels per day, over three-quarters of a billion barrels per year; making Nigeria the sixth largest oil producer in the world. A total of 6.1 billion barrels of crude oil has been produced through 1977. Approximately one-fourth of current crude oil production comes from offshore fields. As shown in Table II-l, Nigeria's annual production has increased steadily, except for two periods of decline. The first production reversal occurred in 1967 and 1968 , as the result of the Biafran War. The second occurred in 1975, as the result of the combination of world-wide decline in crude oil demand, and the increased availability of crude oil from such new sources as the North Sea and Alaska. 
Table II-1

Crude Oil Production History of Nigeria (Thousand Barrels)

\begin{tabular}{lrrr} 
Year & Daily Average & Total & Cumulative \\
\cline { 2 - 3 } 1958 & 5.1 & 1,876 & \\
1959 & 11.2 & 4,096 & 1,876 \\
1960 & 17.4 & 6,367 & 5,972 \\
1961 & 46.0 & 16,802 & 12,339 \\
1962 & 67.5 & 24,624 & 29,141 \\
1963 & 76.5 & 27,913 & 53,765 \\
1964 & 120.5 & 43,997 & 81,678 \\
1965 & 274.2 & 100,065 & 125,675 \\
1966 & 417.6 & 152,428 & 225,740 \\
1967 & 319.1 & 116,462 & 378,168 \\
1968 & 141.7 & 51,732 & 494,630 \\
1969 & 540.3 & 197,204 & 546,362 \\
1970 & $1,083.1$ & 395,331 & $1,138,897$ \\
1971 & $1,531.2$ & 558,888 & $1,697,785$ \\
1972 & $1,820.7$ & 664,546 & $2,362,331$ \\
1973 & $2,054.3$ & 749,820 & $3,112,151$ \\
1974 & $2,255.0$ & 823,064 & $3,935,215$ \\
1975 & $1,783.2$ & 650,885 & $4,586,100$ \\
1976 & $2,072.5$ & 756,449 & $5,342,549$ \\
1977 & $2,085.1$ & 761,062 & $6,103,611$
\end{tabular}

Source: Ministry of Mines and Power, Petroleum Division's Annual Reports Central Bank of Nigeria - Economic and Financial Review Direct Communications to the secretariat. 
Overall, from 1958 to 1977, Nigeria's production increased at an average annual rate of nearly 37 percent, and at an average rate of over 20 percent per year during the last ten years. The highest annual production occurred in 1974, when Nigeria produced 823.1 million barrels.

Exploration and Development Drilling Activity

From 1956 through 1977, 2,754 holes have been drilled in the search and development of oil and natural gas in Nigeria. The historical drilling activity is shown in Table II-2. Of the total, approximately onefourth, or 759 wells, were drilled as exploration wells. Nearly half, 346 of the exploratory wells, were successful in finding oil or natural gas. Of these, 304 wells, or nearly 90 percent, found oil.

A total of 1,997 development wells have been drilled, of which 85 percent or 1,699 wells were successfully completed as oil or natural gas wells. Of these, 96 percent or 1,638 development wells were completed as oil wells; 298 development wells were dry.

In the aggregate, Nigeria has had a high finding success average, as 2,045 exploratory and development wells, or nearly three-fourths of the total wells drilled from 1956 through 1977, found oil and/or natural gas.

Drilling activity during the 21-year history peaked in 1972, when 258 wells were drilled, or 11 percent of the total. However, exploration drilling peaked 5 years prior, in 1967, when 79 exploratory wells, 10 percent of the total, were drilled.

Producing Oil Fields

Approximately 130 fields produce oil in Nigeria. Nearly one-half of the oil. fields each have produced less than 5 million barrels of oil yearly at their peak and over one-third have produced less than one million barrels per year, as shown in Table II-3.

\footnotetext{
1/ Produced at the specified rate for at least three successive years.
} 
Table II-2

Nigeria Historic Drilling Record는

$(1956-1977)$

$\underline{\text { Year }}$

\section{Exploratory Wells}

$$
\text { oil }
$$$$
\text { Gas }
$$

Dry

Total

Development Wells

Oil

Gas

Dry

Total

Grand

Total

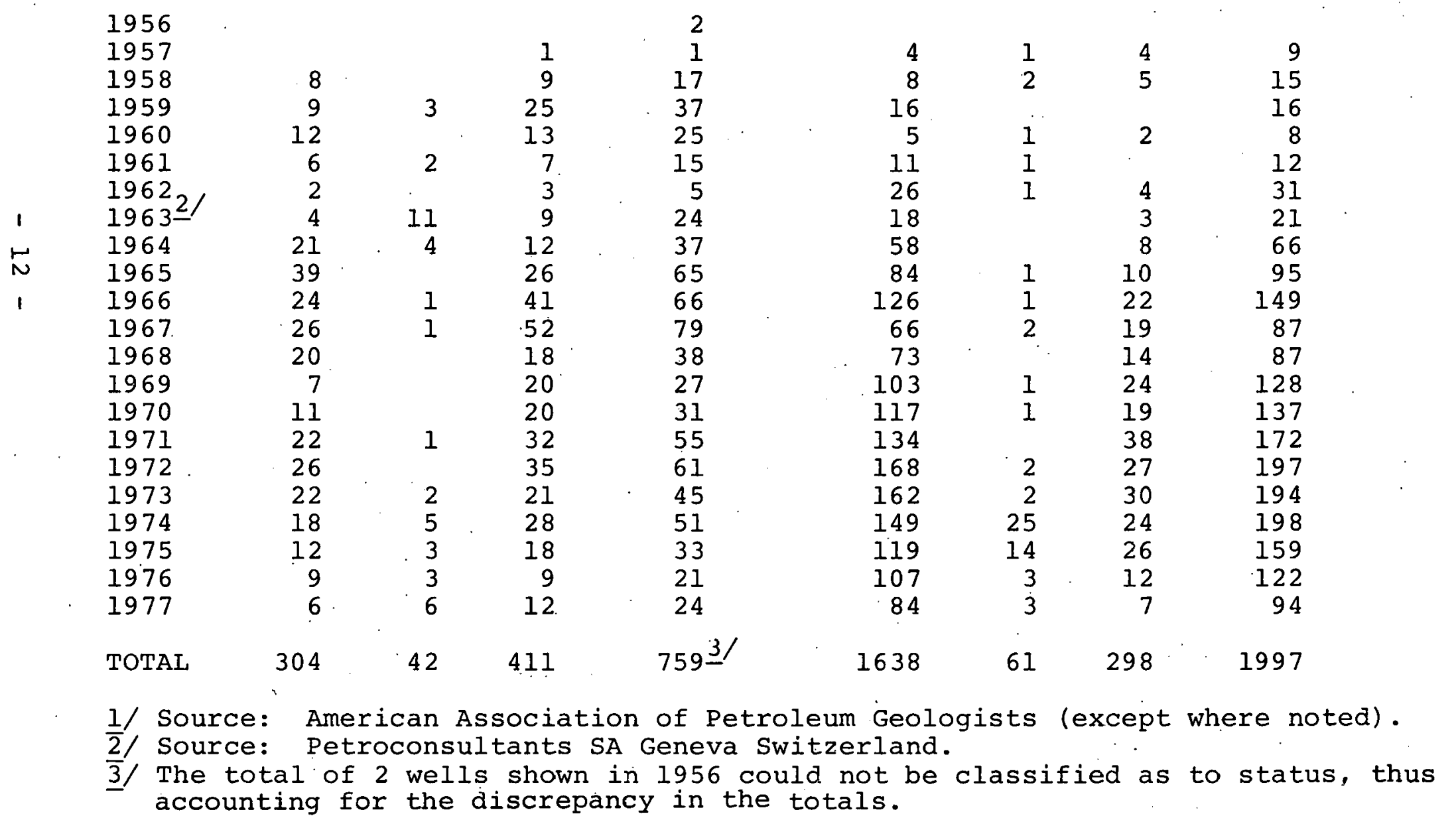

2
10
32
53
33
27
36
45
103
160
215
166
125
155
168
227
258
239
249
192
143
118
175 
Table II-3

Historical Peak Production Rate of Nigerian Oil Fields I]

Number of
Fields 2 /

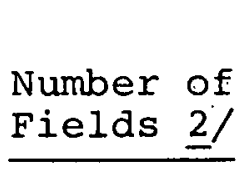

0

1

1

2

1

5

3

4

22

17

13

22

6

8

105 TOTAL
Yearly Average Production Range Greater Than:

50 Million Barrels 45 Million Barrels 40. Million Barrels 35 Million Barrels 30 Million Barrels 25 Million Barrels 20 Million Barrels 15 Million Barrels 10 Million Barrels 5 Million Barrels 3 Million Barrels

I Million Barrels 0.5 Million Barrels $<0.5$ Million Barrels

1/ Peak based on average production within the range for at least 3 successive years during the life of the field. See Appendix $D$ for detailed field production data.

2/ Fields with a two-year production history or less are not included; thus, there is a discrepancy between the field totals of this table and Appendix D. Also, aggregated field production is considered as one field. 
Although five Nigerian fields had produced more than 30 million barrels yearly, through 1977 , none had produced more than 50 million barrels per year.

It is estimated that seven of Nigeria's fields are known giant fields. In addition, there are three probable and four possible giants.2\% The earliest giant, Bomu field, was discovered in 1958, and the most recent, Nembe Creek, was discovered in 1973. All but one of the giant fields were discovered within the period 1958 to 1969, as shown in Table II-4. The known giant fields account for over one-fourth of Nigeria's historic production through 1977, but they provided only one-fifth of the oil produced in 1977. The seven known giants and the seven apparent giants, including a few additional fields whose production records cannot be disaggregated from the giants, have produced about onehalf of Nigeria's historic production, and over one-third of the 1977 production, thus indicating the importance of these few major fields as sources of oil.

It is likely that a few more giant oil fields will be discovered as exploration progresses. However, the status of Nigeria's development is well advanced; thus, the probability of finding many more giant fields is remote. It is also possible that as development continues, some of the giants in the probable or possible category may not achieve that rank.

The peak number of 17 oil field discoveries occurred in 1965, and nearly one-third of Nigeria's producing oil fields were discovered during the threeyear period from 1965 through 1967. The cumulative production through 19.77 from those discoveries totals over two billion barrels. Since that time; the number of oil field discoveries have declined. Table II-5 shows the number of oil fields discovered per year and the cumulative production backdated to the year of discovery.

2/ Partly based on the report entitled, Giant Oil Fields and World Oil Resources, Richard Nehring, Rand, June 1978, p. 138. 
TABLE II-4

THE MAJOR OIL FIELDS OF NIGERIA I/

$\underline{\text { RANK/FIELD }}$

GIANTS: $2 /$

1. $\mathrm{BOMU}$

2. IMO RIVER

3. OKAN*

4. MEREN *

5. JONES CREEK

6. FORCADOS YORKI

7. NEMBE CREEK 3/

TOTAL

\begin{tabular}{c}
1977 \\
PRODUCTIO \\
\\
\\
10.9 \\
21.2 \\
17.4 \\
26.7 \\
30.5 \\
38.4 \\
11.7 \\
\hline
\end{tabular}

156.8
290.4

338.6

247.5

278.8

275.9

272.2

11.7

$1,715.1$
DISCOVIRY

YEAR

1958

1959

1964

1965

1967

1968

1973

\section{PROBABLE GIANTS:}

\section{KOKORI 4 / \\ 10. OBAGIㄴ/}

TOTAL

\begin{tabular}{l}
13.1 \\
22.4 \\
20.4 \\
\hline 55.9
\end{tabular}

232.2

336.8

145.9

714.9
1961

1961

1966

\section{POSSIBLE GIANTS:}

11. DELTA SOUTH*

12. MB. BEDE 6

13. EKPE*

14. ODIDI

TOTAL

GRAND TOTAL
13.7

20.1

12.8

17.7

\begin{tabular}{l}
64.3 \\
277.0 \\
\hline
\end{tabular}

158.0

193.6

118.9

106.9

577.4

$3,007.4$
1965

1966

1969

1967

* Indicates offshore fields.

1/ Principal Source: Giant Oil Fields and world Oil Resources, Richard Nehring, Rand, June 1978, p. 138 .

2/ Definition: Contains at least $500 \mathrm{million}$ barrels of recoverable oil.

3/ Ranked on the basis of paper presented at AAPG-SEPM Annual Convention, April 1-4, 1979 .

4/ Also includes the production of the Afiesere, Eriemu and Oweh fields.

$5 /$ Obagi field includes the production of the Erema field.

6/ Mirede field includes the production of the Ebocha fleld. 
Table II-5

The Number of Producing oil Fields Identified By Year of Discovery and Their Cumulative Production

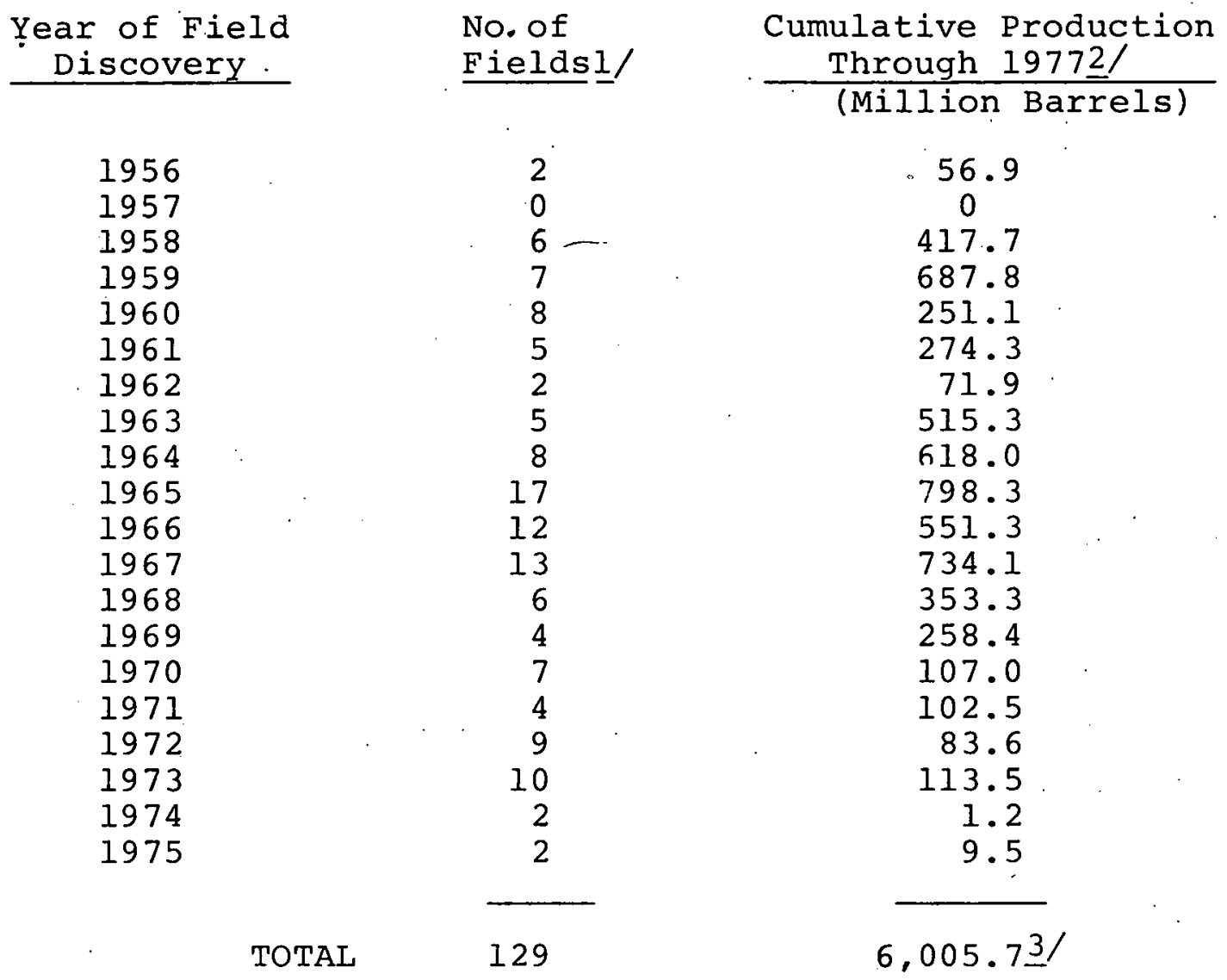

I/ Fields which have produced or are on production; non-producers are not counted.

2/ Some distortions occur as a result of the production of several fields with various discovery-years being aggregated.

3/ Actual cumulative production is 6.1 billion barrels; the difference is in part due to rounding of numbers but also due to minor errors in field production data which cannot be accounted for. This report should not be considered the official source of data. 
Domestic Crude Oil Market and Trade

Crude oil makes à significant contribution to the Nigerian economy. $3 /$ The extent to which crude oil will continue to be an important export commodity depends on the quantity of crude oil that remains to be discovered and developed, the rate at which it can be produced, and the availability of supply in excess of domestic consumption.

Nigeria's crude oil is marketed in almost every part of the world. Approximately three percent of its production is consumed domestically. Table II-6 provides a six-year historical resume of the Nigerian crude oil exports and markets. During the last three years, Nigeria consumed an average of 23.9 million barrels annually, 65.5 thousand barrels per day. 4 During the same period, production averaged 743.8 million barrels annually, 2.03 million barrels per day. The principal markets for Nigerian crude in 1977 were the United States and The Netherlands $/$; they account for over 50 percent. of Nigeria's exports. The percentage that Nigerian crude represents of the importing countries's total demand is shown in Table II-7.

Natural Gas Production and Development

The natural gas industry of Nigeria is underdeveloped because of limited domestic demand and foreign marketing opportunity. The opportunity to utilize natural gas for greater domestic use and exports has future potential.

Domestic consumption of natural gas began in 1963, when one billion cubic feet. (Bcf) were consumed. Since then, consumption has increased to $18.5 \mathrm{Bcf}$ in 1976 . This represents approximately 2 percent of Nigerian gas production. Total natural. gas production in 1977 was an estimated 757 Bcf; nearly 739 Bcf were flared.I

3/ Crude oil exports accounted for 91 percent of Nigeria's foreign exchange earnings, equivalent to over 9 billion U.S. dollars (1978).

4/ 1974 - 24.6 million barrels of oil; 1975 - 24.5 million barrels; and 1976 - 22.9 million barrels.

5/ Most of The Netherlands's imports are re-exported as refined products.

6/ The export of Nigerian liquefied natural gas (LNG) to the United States has been proposed.

7/ Not marketed. 
TABLE II-6

NIGERIA'S CRUDE OIL EXPORTS, 1972-1977

(THOUSAND BARRELS PER DAY)

\begin{tabular}{|c|c|c|c|c|c|c|}
\hline DESTINAT ION & 1977 & 1976 & 1975 & 1974 & 1973 & 1972 \\
\hline$\frac{\text { NORTH AMERICA }}{\text { of which: }}$ & 812.5 & 746.5 & 538.9 & 703.3 & 567.9 & 457.3 \\
\hline $\begin{array}{l}\text { Canada } \\
\text { USA }\end{array}$ & $81 \overline{2} .5$ & $\begin{array}{r}8.5 \\
738.0\end{array}$ & $\begin{array}{r}11.1 \\
527.8\end{array}$ & $\begin{array}{r}2.9 \\
700.4\end{array}$ & $\begin{array}{r}32.3 \\
535.6\end{array}$ & $\begin{array}{r}35.7 \\
421.6\end{array}$ \\
\hline LATIN AMERICA & $\underline{386.6}$ & 222.8 & 234.2 & 241.1 & 278.3 & $\underline{115.4}$ \\
\hline $\begin{array}{l}\text { Of which: } \\
\text { Brazil } \\
\text { Trinidad \& Tobago } \\
\text { Uruguay } \\
\text { British Territories }\end{array}$ & $\begin{array}{c}34.8 \\
- \\
129.6\end{array}$ & $\begin{array}{r}18.1 \\
\overline{8} .5 \\
196.2\end{array}$ & $\begin{array}{c}- \\
\overline{3} .7 \\
17 \overline{1} .8\end{array}$ & $\begin{array}{r}- \\
\overline{5} .6 \\
175.0\end{array}$ & $\begin{array}{r}5.3 \\
13.7 \\
13.1 \\
227.1\end{array}$ & $\begin{array}{r}20.0 \\
- \\
8.3 \\
87.1\end{array}$ \\
\hline$\frac{\text { WESTERN EUROPE }}{\text { of which: }}$ & 785.1 & 997.2 & 860.4 & $\underline{1,110.8}$ & $1,002.9$ & $1,080.0$ \\
\hline $\begin{array}{l}\text { Belgium \& Luxembourg } \\
\text { Denmark } \\
\text { France } \\
\text { Germany (E.R.) } \\
\text { Italy } \\
\text { Netherlands } \\
\text { Norway } \\
\text { Sweden } \\
\text { United Kingdom }\end{array}$ & $\begin{array}{r}3.4 \\
1.3 \\
170.1 \\
115.4 \\
26.7 \\
297.7 \\
14.8 \\
16.5 \\
135.0\end{array}$ & $\begin{array}{r}8.9 \\
5.1 \\
184.9 \\
121.3 \\
14.8 \\
439.7 \\
11.3 \\
14.0 \\
192.2\end{array}$ & $\begin{array}{r}13.0 \\
19.3 \\
196.0 \\
108.5 \\
19.8 \\
239.4 \\
14.3 \\
22.0 \\
213.7\end{array}$ & $\begin{array}{r}9.0 \\
10.1 \\
212.5 \\
138.4 \\
67.6 \\
315.7 \\
11.1 \\
13.9 \\
320.5\end{array}$ & $\begin{array}{r}17.2 \\
21.8 \\
262.4 \\
61.9 \\
46.4 \\
266.5 \\
5.7 \\
22.3 \\
297.7\end{array}$ & $\begin{array}{r}12.1 \\
29.3 \\
285.1 \\
72.9 \\
77.6 \\
208.4 \\
11.7 \\
31.1 \\
329.0\end{array}$ \\
\hline AFRICA & 46.0 & 38.1 & 32.2 & 34.1 & 30.4 & 25.8 \\
\hline $\begin{array}{l}\text { Ghana } \\
\text { Ivory Coast } \\
\text { Senegal } \\
\text { Sierra Leone }\end{array}$ & $\begin{array}{r}19.4 \\
13.6 \\
4.1 \\
3.6\end{array}$ & $\begin{array}{r}17.7 \\
8.0 \\
6.2 \\
3.9\end{array}$ & $\begin{array}{r}12.3 \\
10.6 \\
.5 .1 \\
4.2\end{array}$ & $\begin{array}{l}- \\
-\end{array}$ & $\begin{array}{r}12.1 \\
7.9 \\
4.6 \\
4.6\end{array}$ & $\begin{array}{r}5.2 \\
10.7 \\
4.7 \\
4.5\end{array}$ \\
\hline$\frac{\text { ASIA AND FAR EAST }}{\text { of which: }}$ & - & 8.6 & 47.6 & 90.1 & 98.6 & 77.6 \\
\hline Japan & - & 8.6 & 47.6 & 90.1 & 98.6 & 76.5 \\
\hline TOTAL & .030 .2 & .013 .2 & 1.713 .3 & $2,179.4$ & $1,978.1$ & $1,756.1$ \\
\hline
\end{tabular}

Source: OPEC Annual Statistical Bulletin 1977 - September 1978, p.71.

Note: No effort has been made to reconcile balances. 
Table II 7

Nigerian Crude Oil Export Markets: 1977

(Thousands Barrels Per Day)

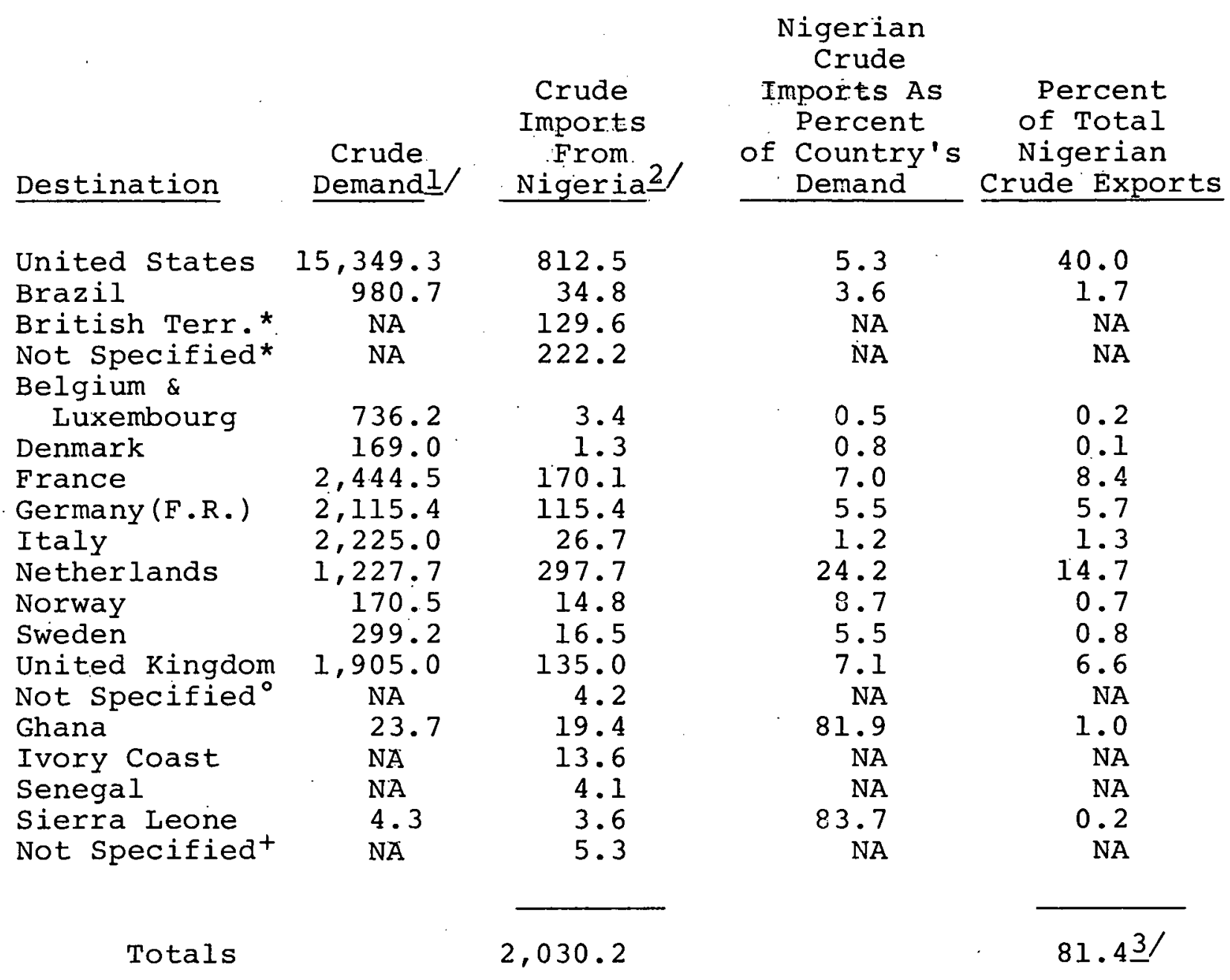

NA: Not Available

1/ International Petroleum Annual, June 1, 1979

2/ Organization of Petroleum Exporting Countries, Sept. 78, p.71.

3/ Because of unavailable data, this total is not complete.

* in Latin Anerica

- in Western Europe

+ in Africa 
SECTION III

The Future Petroleum Prospects of Nigeria

Ultimately Recoverable Oil

Petroleum exploration in Nigeria through 1977

resulted in the discovery of approximately 18.7 billion

barrels of recoverable oil; cumulative production

totalled approximately 6.1 billion barrels. Therefore, 12.6 billion barrels of proved reserves remain to be recovered from the fields of Nigeria discovered through 1977.

Post-1977 exploration and development drilling will result (and has resulted) in further discoveries and additional capability to produce. An analysis of the historical activity and the geology of the Niger Delta provides a basis for estimating the undiscovered quantities of crude oil that may be found as exploration and development continue.1/

The analyses of undiscovered recoverable oil resources indicate that from 1.8 billion to 22.8 billion barrels of oil remain to be discovered. The low estimate has a 95 percent probability and the high estimate has a 5 percent probability. The statistical mean estimate of undiscovered recoverable oil is 8.4 billion barrels. $2 /$

Based on the statistical mean value of undiscovered oil resources and proved reserves, as of the end of 1977 , 21.0 billion barrels of oil remain to be recovered. Sixty percent of the remaining oil is proved reserves associated with discovered fields. The undiscovered recoverable resources of 8.4 billion barrels will be found in new fields, most of which will be small, although a few giant or near-giant fields will be discovered.

I/ The methodology of estimating the undiscovered recoverable oil resources is discussed in section.IV.

2/ The statistical mean value has a statistical probability of 38 percent. 
An alternative scenario to the single point projection of ultimately recoverable oil may be made by using a 30 percent plus or minus variance from the ultimate recoverable oil volume based on the statistical mean. Nigeria's remaining recoverable resources in this instance would range from 18.5 billion to 23.5 billion barrels. The range is illustrated in Figure III-l. The 30 percent variance is within the normal limits experienced in historical revisions of proved reserves estimates.

Future Crude Oil Production Rates

The methods used herein to develop possible maximum production patterns are a modification of the concepts of M. King Hubbert. 3 . The logistic curves illustrated in Figure III-2 depict annual production over time; the area beneath the curve represents the ultimately available or recoverable oil. The modified curve is shifted or "force fit" to the right of the "fit" curve. The purpose of the modification is to compensate for the reversal in the historical production trend caused by market demand deciline and subsequent dampening of exploration and development. The "fit" logistic curve suggests that Nigeria's production theoretically would have peaked at 3.8 million barrels in the early $1980^{\prime} \mathrm{s}$ and, subsequently, production would have declined to an average annual rate of more than 20 percent. The two curves assume that the statistical mean value of undiscovered recoverable oil would be found and developed.

It is assumed, based on the statistical mean, that if exploration and development were accelerated at this time, a maximum peak production of 3.3 million barrels per day could be attained in the mid-1980's. The assumption is illustrated in Figure III-3. Figure III- 3 also shows the historical production trend from 1960 through 1977. The area beneath the asymmetrical bell-shaped curve represents the ultimately recoverable crude oil resources of approximately 27.1 billion barrels; the remaining discovered and undiscovered (based on the statistical mean) recoverable oil, plus the cumulative production. The future production levels that might be expected from Nigeria, determined by reservoir and geological conditions and various rates of exploration

3/ Discussed in detail in Appendix A. 


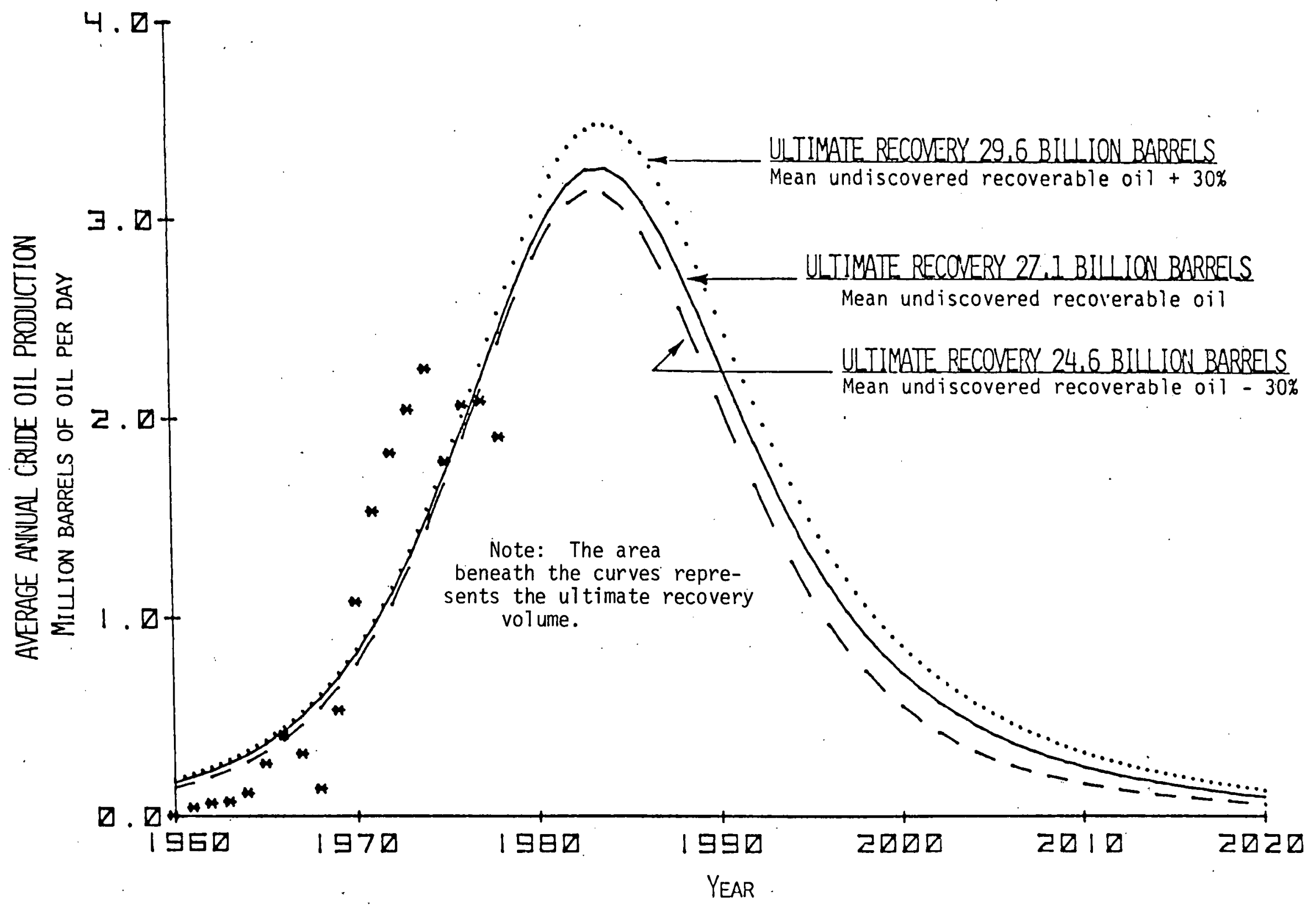

Figure III-1 - Sensitivity of maximum production capability profiles. 


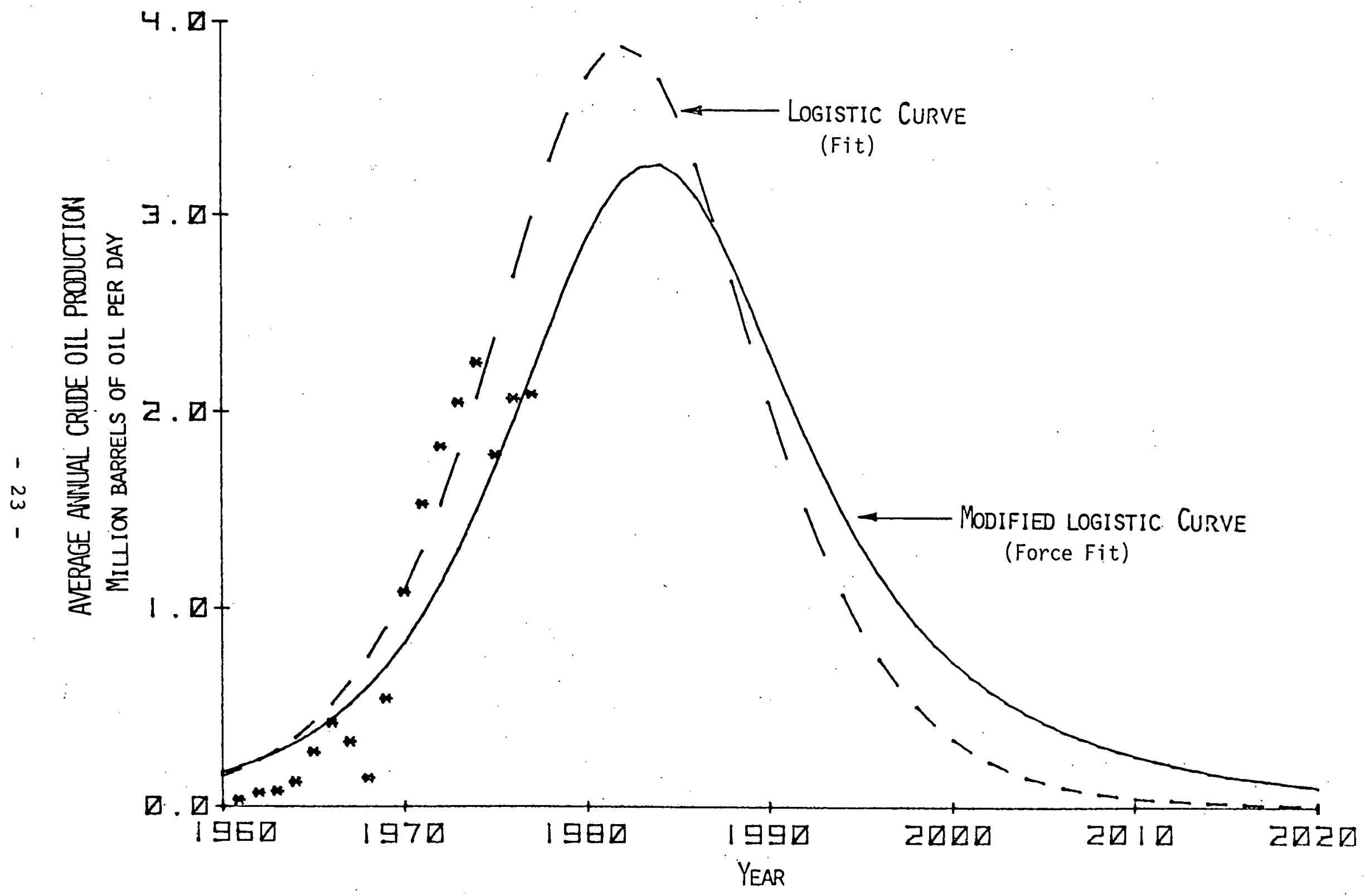

Figure III-2 - Maximum production capability profiles using mean ultimate recovery $\left(27.1 \times 10^{9}\right.$ bbl) for Nigeria. 


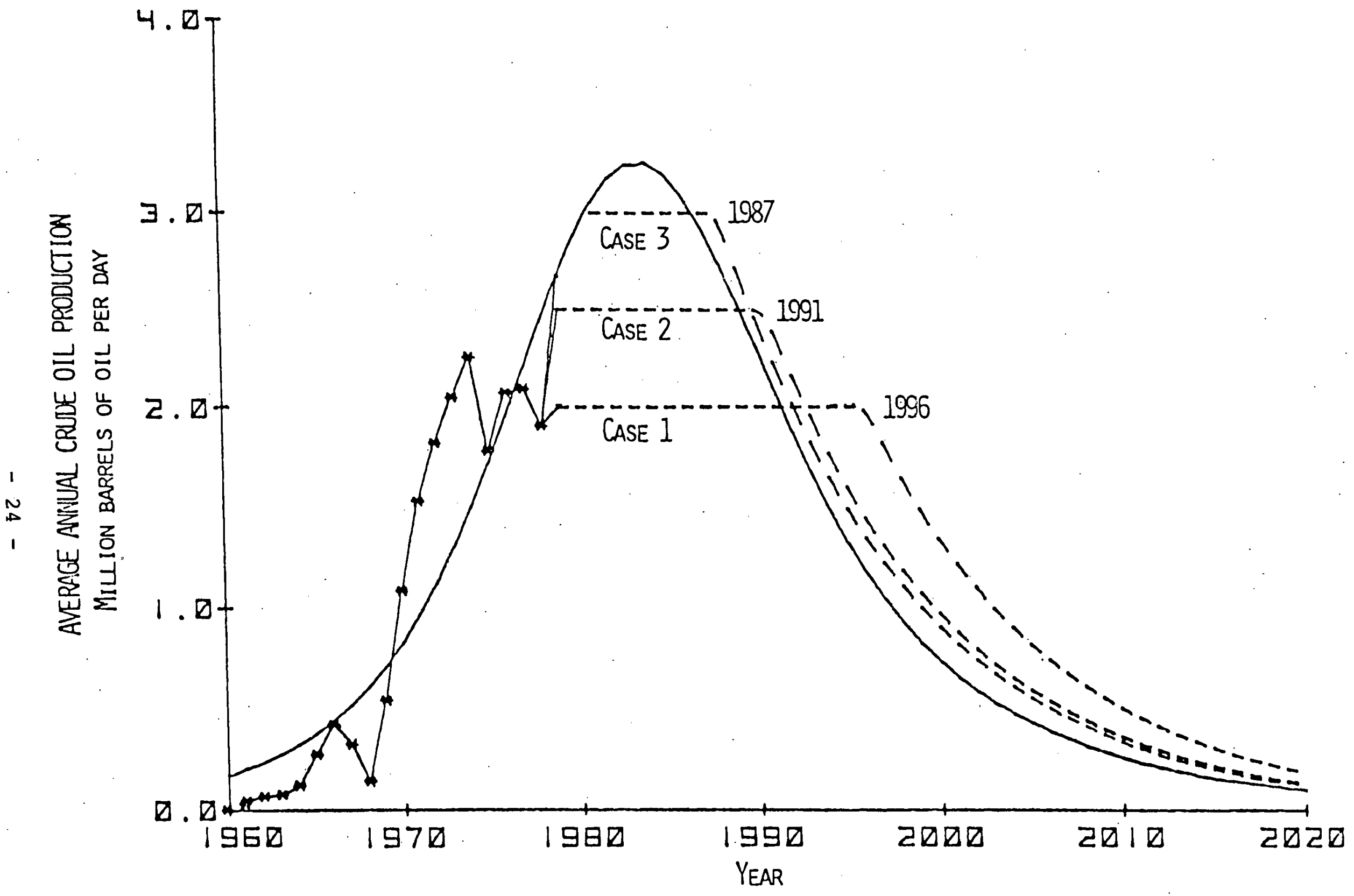

Figure IIII-3 - Historical and projected production profiles based upon the mean ultimate recovery. 
and development efforts, are illustrated in Cases 1 through 3. Case 3 depicts a production growth rate of 9.3 percent from the 1977 production of 2 million barrels per day. That level of production could be sustained through 1987. Production would decline thereafter at an assumed average annual rate of approximately 10 percent, and in 1990 it would be about $2.23 \mathrm{million}$ barrels; subsequently, declining to 1.35 million in 1995, to 0.82 million in the year 2000 , and to 0.50 million barrels per day in 2005. Before the year 2010, 95 percent of Nigeria's recoverable oil resources would be depleted under the stated condition.

Table III-1 shows that production rates for the three cases in five-year increments, the year in which production would decline, and the year when 95 percent of Nigeria's ultimately recoverable crude oil would be depleted.4 The lower rates of constant production are illustrated by cases 1 and 2; the durations of the lower rates of production are sustained for a longer period of time, than for case 3 .

Implicit in each of the three cases is that the capital investment necessary to provide the ancillary processing, storage and transportation facilities would be available. Case 3 represents the optimum investment rate. Cases 1 and 2 indicate lower rates of investment and, therefore, decreased exploration and development. Given that exploration and development activity has slowed, it is believed that Nigeria's future production trend is most likely to be in the range of Cases 1 and 2 .

The ultimate recoverable resource analysis, which drives the production estimates, is based on the information available at this time and the ultimate recovery value of the statistical mean. The production estimates do not reflect possible "surprises" or "disappointments" which cannot be predicted or built into the analytical process. However, the sensitivity of a 30 percent lower or higher ultimate recoverable resource estimate changes the estimated maximum annual capability only by a plus or minus six percent.

4/ The methodology used to determine the production rates is discussed in the Appendix $A$. 
Table III-1 - Alternate Production Schedules for Nigeria.

CASE I (2 MM bopd)

\begin{tabular}{|c|c|c|c|c|c|c|c|}
\hline \multirow{2}{*}{$\begin{array}{c}\text { Probability } \\
\text { levels, } \\
\text { percent }\end{array}$} & \multicolumn{5}{|c|}{ Million Barrels of 0 il Per Day } & \multirow{2}{*}{$\begin{array}{l}\text { Year } \\
\text { decline } \\
\text { begins } \\
\end{array}$} & \multirow{2}{*}{$\begin{array}{c}\text { Year } \\
95 \text { pct } \\
\text { depleted }\end{array}$} \\
\hline & 1980 & 1985 & $\begin{array}{l}\text { YEAR } \\
1990\end{array}$ & 1995 & 2000 & & \\
\hline $\begin{array}{l}95 \\
75 \\
38 \text { (Mean) } \\
25 \\
5\end{array}$ & $\begin{array}{l}2.00 \\
2.00 \\
2.00 \\
2.00 \\
2.00 \\
\end{array}$ & $\begin{array}{l}2.00 \\
2.00 \\
2.00 \\
2.00 \\
2.00\end{array}$ & $\begin{array}{l}1.51 \\
1.84 \\
2.00 \\
2.00 \\
2.00\end{array}$ & $\begin{array}{l}0.92 \\
1.23 \\
2.00 \\
2.00 \\
2.00\end{array}$ & $\begin{array}{l}0.56 \\
0.75 \\
1.38 \\
1.86 \\
2.00 \\
\end{array}$ & $\begin{array}{l}1987 \\
1991 \\
1996 \\
2000 \\
2016 \\
\end{array}$ & $\begin{array}{l}2007 \\
2009 \\
2013 \\
2016 \\
2029 \\
\end{array}$ \\
\hline
\end{tabular}

CASE II (2.5 MM bopd)

\begin{tabular}{rrrrrrrr}
\hline 95 & 2.50 & 2.14 & 1.30 & 0.79 & 0.48 & 1983 & 2005 \\
75 & 2.50 & 2.50 & 1.65 & 1.00 & 0.61 & 1986 & 2007 \\
38 (Mean) & 2.50 & 2.50 & 2.50 & 1.63 & 0.99 & 1991 & 2010 \\
25 & 2.50 & 2.50 & 2.50 & 2.15 & 1.31 & 1993 & 2012 \\
5 & 2.50 & 2.50 & 2.50 & 2.50 & 2.50 & 2006 & 2021 \\
\hline
\end{tabular}

CASE III ( $3.0 \mathrm{MM}$ bopd)

\begin{tabular}{rrrrrrrr}
\hline 95 & 2.90 & 2.10 & 1.28 & 0.77 & 0.47 & 1981 & 2005 \\
75 & 2.90 & 2.44 & 1.48 & 0.90 & 0.54 & 1983 & 2006 \\
38 (Mean) & 2.90 & 3.00 & 2.23 & 1.35 & 0.82 & 1987 & 2008 \\
25 & 2.90 & 3.00 & 2.81 & 1.70 & 1.03 & 1989 & 2009 \\
5 & 2.90 & 3.00 & 3.00 & 3.00 & 2.98 & 2000 & 2017 \\
\hline
\end{tabular}


Therefore, the maximum production capability profile is not very sensitive to a relatively large percentage change in the undiscovered recoverable oill estimates. A larger ultimate recovery value influences the duration of the constant production plateau by extending it. Conversely, a lower ultimate recovery estimate from the statistical mean, 27.1 billion barrels, reduces the duration of the constant plateau production rate. Figure III-4 illustrates constant plateau durations by using a wide range of ultimate recovery estimates at the 2.5 production level. Curve 3 is based on the statistical mean estimate of ultimate recovery; Curves 2 and 4 represent 75 percent and 25 percent probability levels; Curve 1 represents the ultimate recovery based on the 95 percent probability estimate of remaining undiscovered recoverable resources, and Curve 5 is based on the five percent probability estimate.

Remaining Recoverable Natural Gas Resources

The lack of domestic markets and export opportunities have limited the interest in natural gas exploration and development. That which has been discovered has been found incidental to the search for crude oil.

In the absence of a performance history for natural gas field production, this report does not analyze the estimates of Nigeria's discovered natural gas recoverable reserves. One published source has reported Nigeria's proved reserves to 42 trillion cubic feet (Tcf) $5 /$ and another source reported 51.4 Tcf.6/ Either of these magnitudes show that the know inventory of supply is considerably greater than current production; the reserve to production ratio $(\mathrm{R} / \mathrm{P})$ implies a 70 to 86 year supply.

The proportion of natural gas associated with crude oil is relatively high in the Niger Delta. The gas-to-oil ratio averages approximately 800 cubic feet for each barrel of oil.

The occurrence and distribution of natural gas in the Niger Delta is described as follows:

5/ Oil and Gas Journal, 1978.

6/ DeGolyer and MacNaughton. 


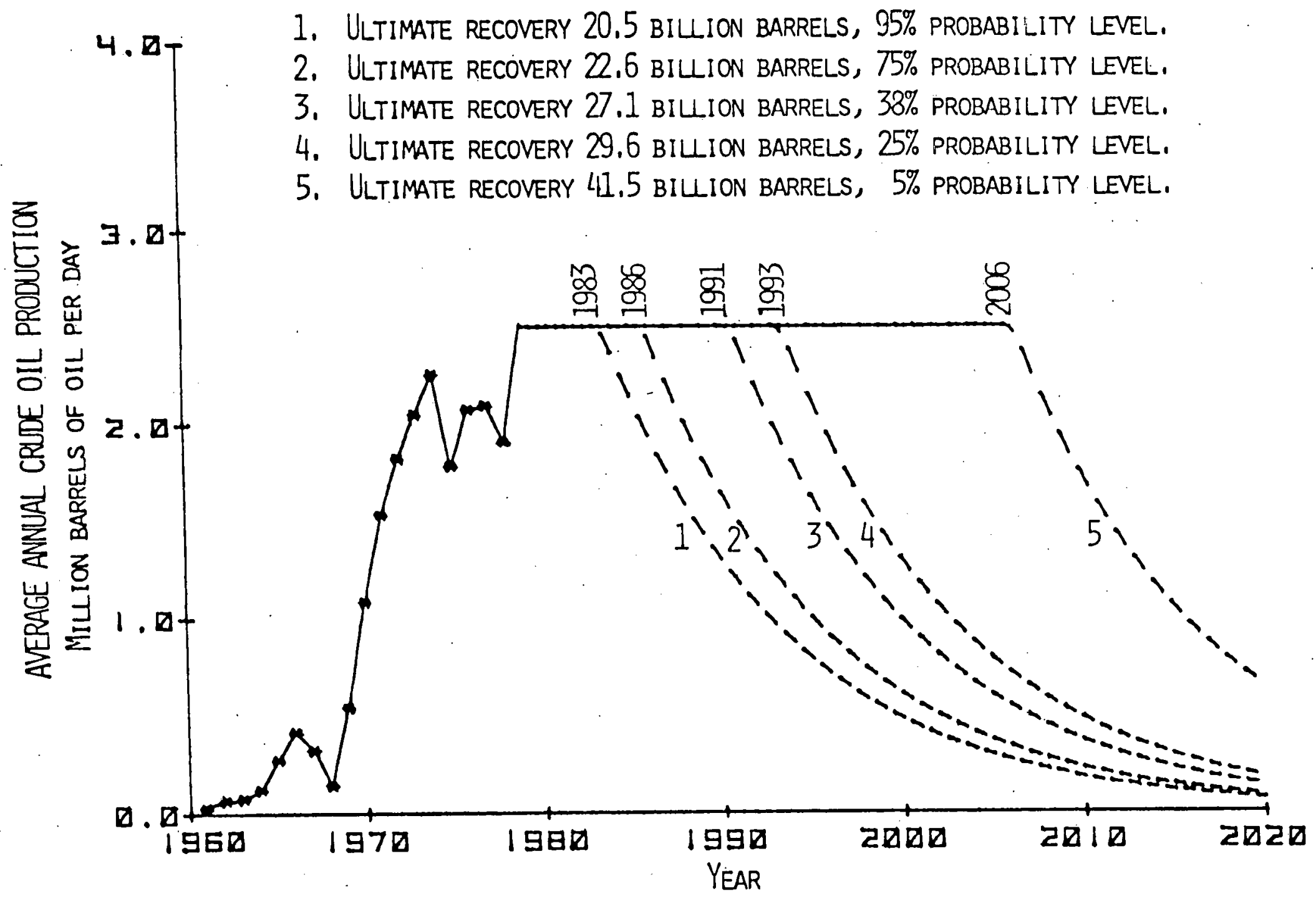

Figure III-4 - Historical and projected crude oil production for five ultimate recoveries (Case 2 - 2.5 MM bopd). 
- Large deposits of natural gas are most likely to be found south. of the main hydrocarbonrich belt, which extends in a general southeast to northwest direction, where there is a narrow series of oil-rich zones; the central part of the Delta is predominantly a natural gas province; and

- The potential for finding natural gas vis-a-vis crude oil appears to increase seaward in a south-easterly direction across the Delta.

Thus, it would appear that the opportunity for controlling exploration programs to selectively or "directionally" search for natural gas is possible.I

The statistical mean estimate of undiscovered natural gas indicates that there may be 81.3 Tcf of natural gas in-place. Based on a recovery factor of approximately 80 percent, the undiscovered recoverable resources may be $65 \mathrm{Tcf}$. Thus, the ultimate recoverable natural gas supplies, discovered proved reserves plus undiscovered recoverable resources, may total over 100 Tcf.

The statistical analysis further indicates that it is 95 percent probable that an estimated 32 Tcf remain to be discovered in-place, of which 25.6 Tcf are recoverable, and a five percent probability that as much as 162 Tcf remain in-place, of which 130 Tcf are recoverable. 8 /

7/ The term "directionality" applies to an explorer's capability to choose the objective of his search, either crude oil or natural gas, based on geological evidence which favors the occurrence of one or the other.

8/ The methodology used to arrive at these quantities is described in section IV. 
Future Natural Gas Production Capability

The rate at which the Nigerian recoverable natural gas will be produced is difficult to assess in the absence of natural gas well performance history. The quantity of gas associated with crude oil, the rate at"which the crude is produced, and finally, the timing of the blow-down 9/ period are some of the factors which will affect the production rate of associated natural gas.

The depletion of 95 percent of Nigeria's ultimately recoverable natural gas resources within the same period as the recoverable oil resources, 30 to, 35 years, would require that natural gas production average slightly over 3 Tcf annually. The actual production, however, would be controlled by sales contracts as well as the reservoir yield rates. Also, natural gas depletion would tend to lag oil depletion because of pressure maintenance programs, etc.

9/ The production and depletion of the gas cap of a crude oil reservoir following the ultimate recovery of the oil. 
Geology and Resource Analysis of Nigeria

Summary of Geology and Resource Analysis

The known petroleum potential of Nigeria is concentrated primarily in the southern part of the country and petroleum occurs for the most part in the Tertiary sediments of the Niger Delta. The Niger Delta covers an area of approximately 41 thousand square miles and it is underlain by thick deltaic sediments reaching an estimated maximum thickness of 30,000 to 40,000 feet.

The Agbada Formation is the main objective in the exploration for oil and gas in southern Nigeria and probably extends across the entire Delta.

The most important geologic structural features in the Niger Delta are the large crescent-shaped growth faults. Elongated anticlines have formed in front of the fault plane, creating "rollover" anticlines, in which most of the large fields have been discovered.

Through 1975, at least 203 field discoveries have been reported, many of which have multi-pay reservoirs. The estimated number of oil fields that may be discovered after 1977 range from 20 to 123, at the 95 percent to 5 percent statistical probability levels, respectively, with a mean estimate of 77 fields. Significant undiscovered oil potential still remains in some of the deeper fault blocks onshore, and there is a prospective pattern of growth faults which occur offshore that may be highly productive.

The gas industry in Nigeria remains relatively underdeveloped. The potential for finding additional natural gas appears likely as development extends seaward in the deeper sediments and in a southeasterly direction across the Delta. 


\section{General Observations}

The knowledge of Nigeria's geology has reached an advanced stage as the result of the work of international oil companies, the Nigerian National Oil Corporation, and the Geological Survey of Nigeria.

One-half of Nigeria is composed of marine and continental sedimentary rocks of Cretaceous, Tertiary and Quaternary age which overlie: the crystalline rocks of Precambrian age, and the other one-half is made up of igneous and metamorphic rocks. Over three-fourths of the igneous and metamorphic rocks are Precambrian in age, while the remaining are younger intrusives and volcanic lavas.

The sedimentary rocks are concentrated principally in the southern part of Nigeria and in the Niger and Benue troughs (Anambra Basin), as shown in Figure IV-I. The troughs are filled with Cretaceous sediment and have a breadth of 95 to 190 miles. The oldest known sedimentary rocks in Nigeria are of the lower Cretaceous (Albian Age). The stratigraphic columnar section of Nigeria is shown in Figure IV-2. The deeply folded sediments are concentrated mainly in the middle basin of the cross River, located on the eastern edge of the Delta. They consist of sandstone, shale and thin striations of limestone. All drill tests in the northern and eastern parts of Nigeria, which penetrated Upper Cretaceous sediments, were dry or revealed only minor oil and natural gas deposits. Lower Cretaceous sediments have shows of petroleum in outcrops and in wells, but no major discoveries have been made to date in the Upper and Lower Cretaceous. The Cretaceous in southern Nigeria, although not considered highly favorable for oil, I/ cannot be ruled out as oil prospective.

1) Schatzl, L.H., Petroleum in Nigeria, Oxford University Press, Idaden, 1969, pp. $1-45$ and 198-210. 


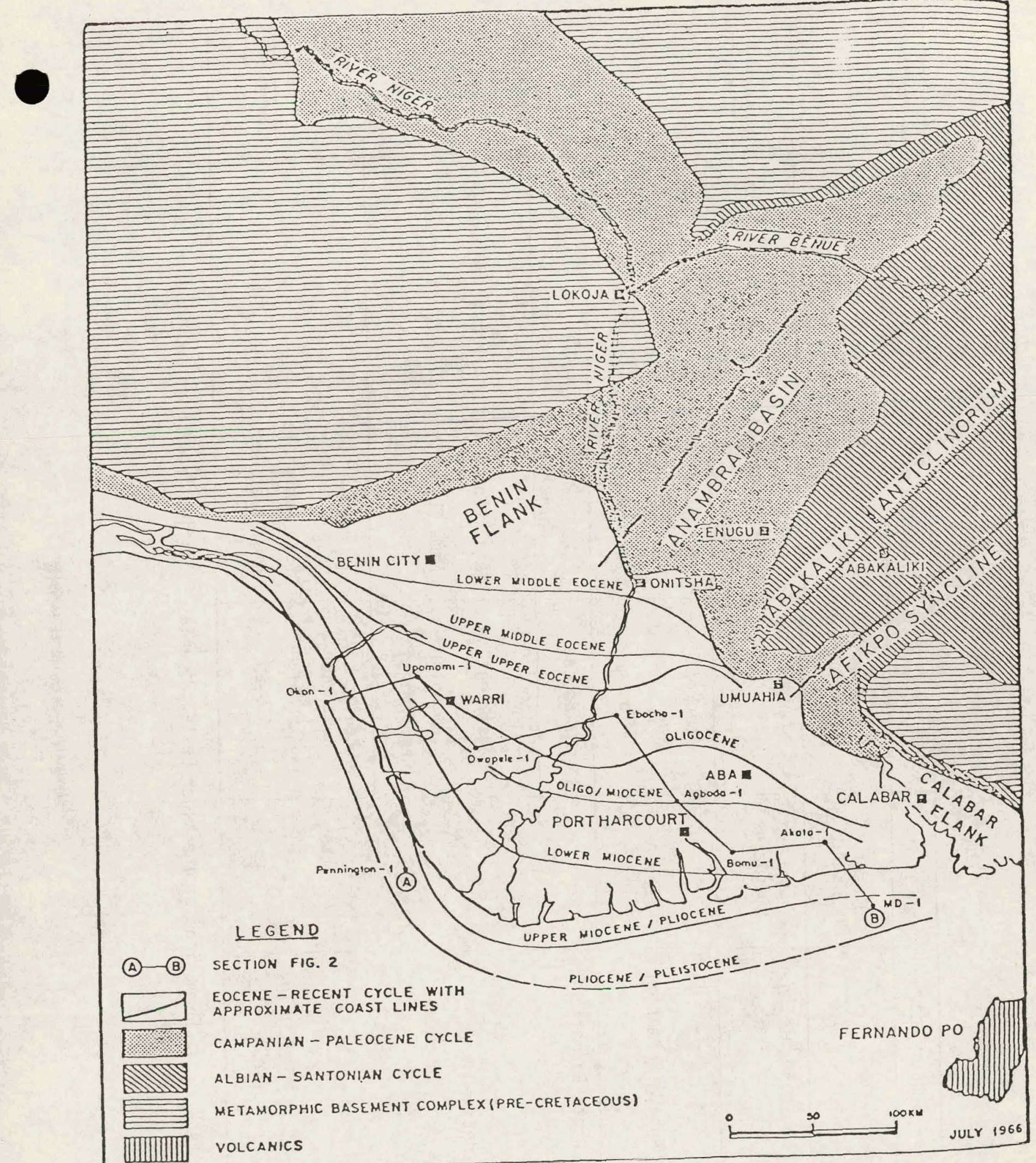

Figure IV-1. General geological map of the Niger Delta and Source: Frankl and Cordry, 1967. 
Niger Delta

\begin{tabular}{|c|c|c|c|c|c|c|}
\hline \multicolumn{3}{|c|}{ Subsurface } & \multicolumn{3}{|c|}{ Surface Outcrops } & \multirow{2}{*}{$\begin{array}{l}\text { Geologic } \\
\text { Period }\end{array}$} \\
\hline $\begin{array}{l}\text { Youngest } \\
\text { Known Age }\end{array}$ & & $\begin{array}{l}01 \text { dest } \\
\text { Known Age }\end{array}$ & $\begin{array}{r}\text { Youngest } \\
\text { Known Age }\end{array}$ & & $\begin{array}{l}01 \text { dest } \\
\text { Known Age }\end{array}$ & \\
\hline Recent & Benin Formation & 01 igocene & $\begin{array}{c}\text { Plio. } \\
\text { Pleistocene }\end{array}$ & Benin:Farmation & Miocene? & \multirow{3}{*}{$\begin{array}{l}\text { Quaternary } \\
\text { Tertiary }\end{array}$} \\
\hline Recent & Agbada Formation & Eocene & $\begin{array}{l}\text { Miocene } \\
\text { Eocene }\end{array}$ & $\begin{array}{l}\text { Ogwashi-Asaba } \\
\text { Formation } \\
\text { Ameki Formation }\end{array}$ & $\begin{array}{l}\text { Oligocene } \\
\text { Eocene }\end{array}$ & \\
\hline \multirow{3}{*}{ Equivalents } & \multirow{3}{*}{$\begin{array}{l}\text { Akata Formation } \\
\text { not known }\end{array}$} & Eocene & L. Eocene & $\begin{array}{c}\text { IMO } \\
\text { Formation }\end{array}$ & Paleocene & \\
\hline & & & $\begin{array}{c}\text { Paleocene } \\
\text { Maestrichtian } \\
\text { Campanian } \\
\text { Camp./Maest. }\end{array}$ & $\begin{array}{l}\text { Nsukka Fm. } \\
\text { Ajali Formation } \\
\text { Mamu Formation } \\
\text { Nkporo Shale }\end{array}$ & $\begin{array}{c}\text { Maestrichtian } \\
\text { Maestrichtian } \\
\text { Campanian } \\
\text { Santonian }\end{array}$ & \multirow{2}{*}{$\begin{array}{c}\text { Upper } \\
\text { Cretaceous } \\
\text { Tower - } \\
\text { Cretaceous }\end{array}$} \\
\hline & & & $\begin{array}{l}\text { Coniacian/ } \\
\text { Santonian } \\
\text { Turonian } \\
\text { Albian }\end{array}$ & $\begin{array}{c}\text { Awgu Shale } \\
\text { Eze Aku Shale } \\
\text { Asu River Group }\end{array}$ & $\begin{array}{l}\text { Turonian } \\
\text { Turonian } \\
\text { Albian }\end{array}$ & \\
\hline
\end{tabular}

Figure IV - 2. Formations of the Niger Delta, Nigeria (Modified from Short and Staüble, 1967) 
Formations of Tertiary age are extensive in southern Nigeria, as significant volumes of such sediments have been deposited in the Delta. The most promising crude oil accumulations in the Tertiary have been found at depths between 9,000 to 11,000 feet in the Miocene age. Generally, the Tertiary sediments have proven to be the most productive, thus explaining the concentration of drilling in Tertiary formations of the Niger Delta. Because this is the most prospective area in Nigeria, this report will hereafter concern itself specifically with the geology of the Niger Delta.

The Geology of the Niger Delta

The 41 thousand square miles of the Niger Delta are underlain by deltaic deposits of Tertiary age which may reach an estimated thickness of 30,000 to 40,000 feet. These deposits are divided into three subsurface formations from the surface downward: the continental, sandy Benin Formation; the deeper transitional Agbada Formation of alternating sands and shales; and the lower marine, shaly Akata Formation.

\section{Benin Formation:}

The Benin Formation consists of predominantly massive, highly porous freshwater-bearing sandstones locally interbedded with thin shale beas. The sands and sandstones of these upper deltaic deposits may represent point-bar deposits, channel fills, or natural levees. The shales may be interpreted as backswamp deposits and oxbow fills or deposits of braided-stream origin. The depocenter of the Benin Formation is in the center of the Niger Delta where it attains a maximum thickness of at least 6,000 feet.

The Benin Formation was deposited across the entire Niger Delta from the Benin-Onitsha area in the north to beyond the present coastline. The shallowest marine shale underlying this sandy, continental sequence has been dated as early Miocene Age. Thus, the total age span is Miocene to Recent. To date, very few hydrocarbon deposits have been found in this highly porous, generally freshwater-bearing formation. 


\section{Agbada Formation:}

The Agbada Formation is the main objective in the exploration for oil in southern Nigeria. Hydrocarbons have been found in the sand intervals from Eocene to probably Pliocene age.

The Agbada Formation underlies the Benin and extends throughout the Niger Delta subsurface. It consists of alternating sandstone and shales of delta-front, distributary-channel and deltaic-plain origin. The alternating sequence of sandstones and shales of the Agbada Formation are cyclic sequences of marine and fluvial deposits. The upper part of the formation has a higher sandstone percentage than the lower part, demonstrating the progressive but highly irregular seaward advance of the Niger Delta through geologic time despite the numerous transgressive sequences found in the Agbada Formation. In the central part of the Delta the formation attains a maximum thickness of 12,000 feet. The age of the formation decreases from Eocene to possible Plio-Pleistocene offshore from the present coastline. The base of the Agbada Formation is defined as the deepest significant sandstone body in all vertical sections throughout the Delta.

\section{Akata Formation:}

The main source rock of the Niger Delta oil province is thought to be the shale of the Akata Formation. The Akata Formation is characterized by a uniform shale development. The prodelta shales are medium to dark gray, sandy or silty, undercompacted, and may contain lenses of abnormally high-pressured siltstone or fine-grained sandstone. The Akata Formation is a marine sedimentary sequence laid down in front of an advancing delta front. Intervals of variable thickness, ranging from 4,500 to 5,000 feet, have been penetrated by some wells. The base has been reached only along the Delta margin; thus, the maximum depth is not known. However, its maximum thickness has been estimated at over 18,000 feet. The shale of the Akata Formation probably extends across the entire Delta area. The known age of the formation ranges from Eocene to Recent. 
The Subsurface Structure of the Niger Delta

The Niger Delta began to build seaward over the edge of the African continent in middle to late Eocene time. The Oligocene and younger Delta sediments are very thick beyond the continental edge. Geophysical evidence indicates a possible thickness of 30,000 to 40,000 feet. Recent marine deposition on the forward slope, represented by the continental slope off the Niger Delta, is a depositional feature and not a primary structural feature. 2 /

The thick, rapid deposition of sediments across the Delta area created conditions which resulted in the movement of large masses of sediment under the influence of gravity. Much of the resultant fault movement is contemporaneous with deposition, producing a thickening of the sedimentary section across the fault plane on the downthrown blocks. Faults which cause such increases in thickness are called "growth faults." They are known to occur also in the Gulf of Mexico coastal area. In general, faults play an important role in the distribution and accumulation of hydrocarbons in the Niger Delta, as shown in Figure IV-3.

Many of the growth faults are crescent-shaped, both in cross-section and in plan view, with the concave side toward the downthrown block. Due to this curvature, the downthrown block tends to slump or rotate along an axis roughly paralleling the fault. If sufficient movement has taken place along a curved fault plane, an elongated anticline is formed in front of the fault, which is called a "rollover" structure. In the Niger Delta such rollover anticlines are small, ranging from 4 to 5 miles along the long axes and 2 to 3 miles across the short axes. Structural mapping shows that in many places a series of growth faults on strike with one another may form a continuous trend extending for tens of miles, roughly parallel with the coastline.

2/ Hospers, J.,"The Geology of the Niger Delta Area," Institute of Geological Sciences, Report No. 70/16, pp. 123-142. 
Figure IV-3

\section{Different Evolutional Stages of the Traps \\ of the Niger Delta}
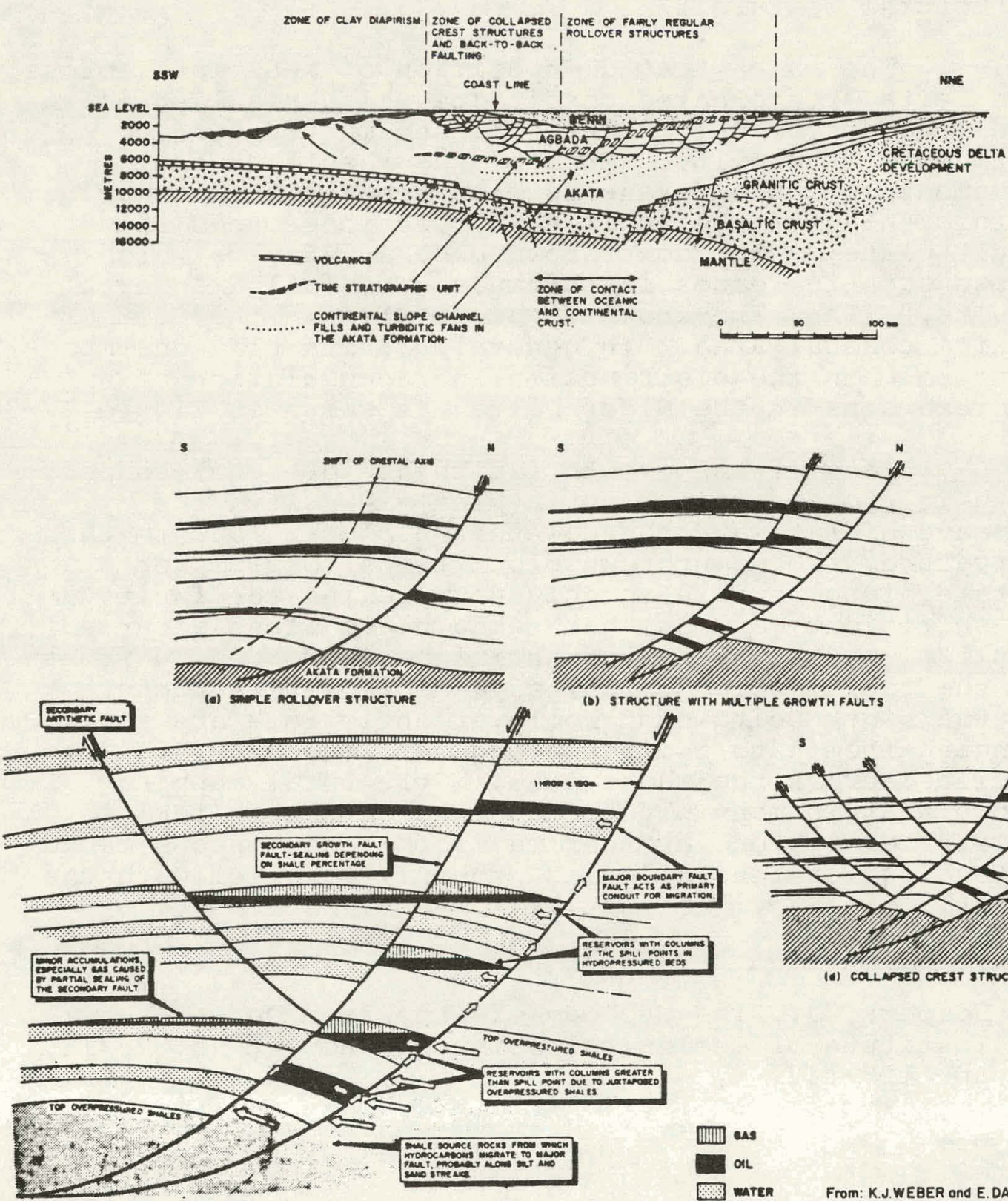

메에 ans

(e) STimuctune wTM ANTITEETIC PAUT

From: K.J.WEBER and E. DAUKURU, in 9 9 . World Petro. Cong. (ponel 4), Tokyo 1973 


\section{The Occurrence of Hydrocarbons}

Most of the hydrocarbon accumulations in the Niger Delta have been found in the sandstones of the Agbada Formation, mostly in traps formed by rollover anticlines. The Benin and Akata Formations have yielded some oil and gas in minor amounts in such structures. The extent of petroleum accumulation in the Agbada Formation may or may not be restricted by subsidiary growth faults or antithetic faults cutting the anticline. Such fault-formed restrictions are most evident in the larger anticlines that normally are expected to be effective traps for oil. The efficiency of such traps are limited by the faults. In addition to the anticlinal traps, hydrocarbons have also been found in fault traps that are not closed on all sides by regional dip.

Many of the oil fields, particularly those in the rollover anticlines, have multiple reservoirs. Few of these reservoirs are full to the structural spill-point and many contain no hydrocarbons at all. Although multiple reservoir fields are common, their existence may not be apparent at the time of a field discovery. Subsequent drilling may reveal that the reservoirs are not stacked vertically but have been dislocated laterally. This is particularly true in the case of fault traps associated with a low angle fault, or, in a rollover anticline whose crest has shifted with depth. This, and the fact that minor faults often control the actual distribution of hydrocarbons within a structural closure, require constant subsurface analysis when developing a field.

Geological Considerations in Resource Appraisal

A brief review of the geology and structural conditions related to the occurrence of hydrocarbons in the Niger Delta is summarized here as a part of the basic input necessary for an appraisal of the undiscovered oil and gas resources in Nigeria. 
A general pattern concerning the hydrocarbon distribution throughout the Delta has been observed and summarized (by Evamy, et al, 1978) as follows:

-- A hydrocarbon-rich belt cuts across the depositional and structural trends of the Delta from southeast to northwest, as shown in Figure IV-4. North and east of the hydrocarbon-rich belt, the gas-to-oil ratio3/is higher, and the recoverable oil reserves of the accumulations found to date are smaller. South of the main hydrocarbonrich belt is a series of narrow oil-rich zones; otherwise, a predominantly gas province occupies a fairly wide part of the central Delta.

-- Known commercial oil accumulations occur predominantly in the structurally highest part of a given macrostructure in the strike sense, despite viable trapping conditions down plunge.

-- Dry holes and marginal oil and gas finds are located predominantly on the southern flanks of the macrostructures.

-- In a given macrostructure, the gas-to-oil ratio increases down plunge and in a generally seaward direction. Hence northern blocks with pronounced landward dips are regarded as being highly prospective for oil.

-- The more downdip a macrostructure is within a megastructure, the greater is the probability of a higher gas-to-oil ratio:

3/ Gas-to-oil ratio denotes the ratio of the volume of gas-bearing reservoir rock to the volume of oil-bearing reservoir rock and not solution gas volume to recoverable oil (GOR). 


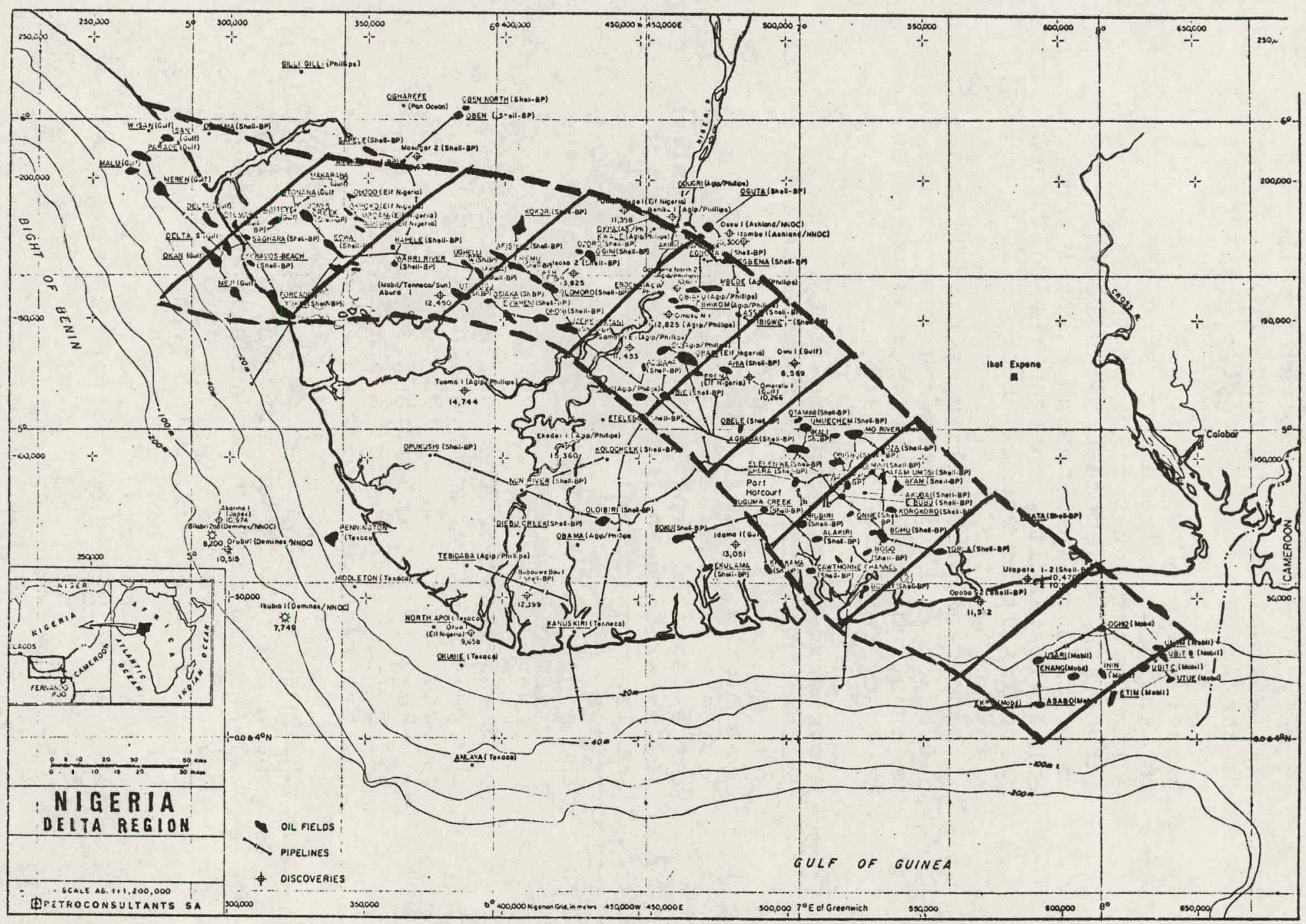

Figure IV-4, Hydrocarbon Rich Belt

Source: Petroconsultants, S.A. 
-- Because of the intensity of faulting and steeply dipping reservoirs of collapsed crest structures, the recoverable reserves can be rather low. Exceptions are reservoirs such as that of the Forcados Estuary field, where a reservoir with a long oil column and concomitantly large areal extend exists at shallow depth. Hydrocarbons in collapsed-crest structures tend to be trapped behind crestal and antithetic faults, whereas the collapsed crest itself is usually barren:

-- Although the probability is high of finding hydrocarbons behind the numerous faults in major structures, commercial discoveries have not been made as yet.

-- Miocene age rocks contain the greater percentage of the total known reserves.

-- Most of the large fields produce from "rollover anticlines" associated with large regional growth faults. The smaller fields are generally associated with smaller growth faults and non-growth faults. There may be a correlation between the magnitude of the throw of a fault and the size of the fields.

-- From the coast to the continental slope the main producing formation (Agbada) becomes progressively thinner. The bulk of the total stratigraphic section offshore is shale, with less of a chance for high quality reservoir rocks.

-- The most important geological features are the growth fault patterns which form the oil and gas field structures and which also may contribute to the migration route of the hydrocarbons from the source beds of the Akata Formation into the paralic sand layers of the Agbada Formation. The paralic cyclic sedimentation pattern is well established. 
Pertinent Exploration Statistics

Some of the drilling and field statistics used in preparing the oil and gas resource assessments are shown below.

A total of 759 exploratory wells were drilled in Nigeria from 1951 through 1977. The total exploratory footage of 8.4 million feet drilled. since 1951 is shown on an annual basis, in Table IV-1.

The total number of flowing wells in Nigeria as of July 1, 1978, was 1,299. Twenty-three oil wells require gas-lift, and 305 wells are shut in. The average production for the first six months of 1978 was 1,671,968 barrels per day. The total cumulative oil production through July 1,1978 , for Nigeria was $6,416,807,589$ barrels.

The total estimated proved reserves as reported by the Oil and Gas Journal were: 18.2 billion barrels of oil and 42 trillion cubic feet of gas. DeGolyer and MacNaughton, in 1977, reported estimated proved reserves of 12.24 billion barrels of oil and 51.42 trillion cubic feet of gas as of January 1, 1977.

Oil and gas field data were partly compiled from the Petroconsultants, S.A. "World Field Files," which include 203 field records of discoveries up to January 1, 1975. Of these, 150 oil field records were used by the engineers in the DOE Energy Information Administration to calculate the estimated remaining reserves from production decline data, recovery data per well, reservoir drive mechanism information, and pressure data. 4 / The original oil-in-place was calculated by using recovery factors, or was determined volumetrically. These field data, plus the data for 17 additional fields, reported as shut in, standing or awaiting development, were used in the resource assesiment study. A total of 36 fields reported in the "World Field Files" did not have sufficient data to make estimates of remaining reserves. Twenty-five of the thirty-six fields are oil fields, five are gas fields, and six are combination oil and gas fields. Many gas fields and probably some oil fields discovered since.

4/ Discussed in detail in Appendix A. 
Table IV-1

Exploratory Footage Drilled in Nigeria

\begin{tabular}{lrr} 
Year & Footage & Cumulative Footage \\
\hline $1951-53$ & 29,000 & 29,000 \\
1954 & 33,000 & 62,000 \\
1955 & 52,000 & 114,000 \\
1956 & 10,200 & 124,200 \\
1957 & 33,500 & 157,700 \\
1958 & 177,500 & 335,200 \\
1959 & 395,900 & 731,100 \\
1960 & 287,000 & $1,018,100$ \\
1961 & 163,300 & $1,181,400$ \\
1962 & 92,800 & $1,274,200$ \\
1963 & 244,500 & $1,518,700$ \\
19641 & 460,345 & $1,979,045$ \\
19651 & 699,332 & $2,678,377$ \\
1966 & 753,195 & $3,431,572$ \\
1967 & 827,277 & $4,258,849$ \\
1968 & 333,636 & $4,592,485$ \\
1969 & 261,566 & $4,854,051$ \\
1970 & 333,261 & $5,187,312$ \\
1971 & 580,106 & $5,767,418$ \\
1972 & 652,966 & $6,420,384$ \\
1973 & 501,418 & $6,921,802$ \\
1974 & 557,365 & $7,479,167$ \\
1975 & 417,707 & $7,896,874$ \\
1976 & 219,694 & $8,116,568$ \\
19772 & 290,230 & $8,406,798$
\end{tabular}

1/ Data for 1951-1965 from: L. H. Schatzl, 1969. 2/ Data for 1966-1977 from: AAPG Bulletins. 
1974, have not been placed on production, and little data is available for them. Thus, reserve information on many recent discoveries is unavailable.

The ultimate recovery of the 167 fields analyzed in detail is discussed in the aggregate in Appendix A. These same field data were used in the resource appraisal, below.

Figure. IV-5 depicts the frequency distribution of the 167 oil fields by size in barrels of oil equivalent in-place (BOE-IP).5/ The field sizes range from approximately 8.3 million barrels to nearly 2 billion barrels of BOE-IP. A lognormal distribution provides the "best curve fit" for the field size data. This information is used to estimate the field size distributions of the undiscovered resources.

Resource Appraisal by Analysis of Finding-Rates

The ultimate purpose of determining the findingrate or discovery rate within a petroleum province is to permit statistically valid projections of resource availability based upon historic data within a given geological and economic frame of reference. In an attempt to minimize the effects of economic and political variations, the historical finding-rates are expressed in units of oil or gas discovered per unit foot of exploratory drilling and as a function of cumulative exploratory drilling. Major assumptions must be made in applying finding-rate methods for projecting remaining resources. The finding-rate methods, (1) are to be applied directly only to semi-mature or maturely drilled producing areas, (2) are to be applied to an area of fairly fixed boundaries (sample size must not change radically), and (3) do not allow for any radical "surprises" in petroleum exploration or significant

"improvements" in exploration technology or economics.

5/ Barrels of oil equivalent also includes associated gas converted into barrels: conversion is 6,000 cubic feet per barrel of oil. 


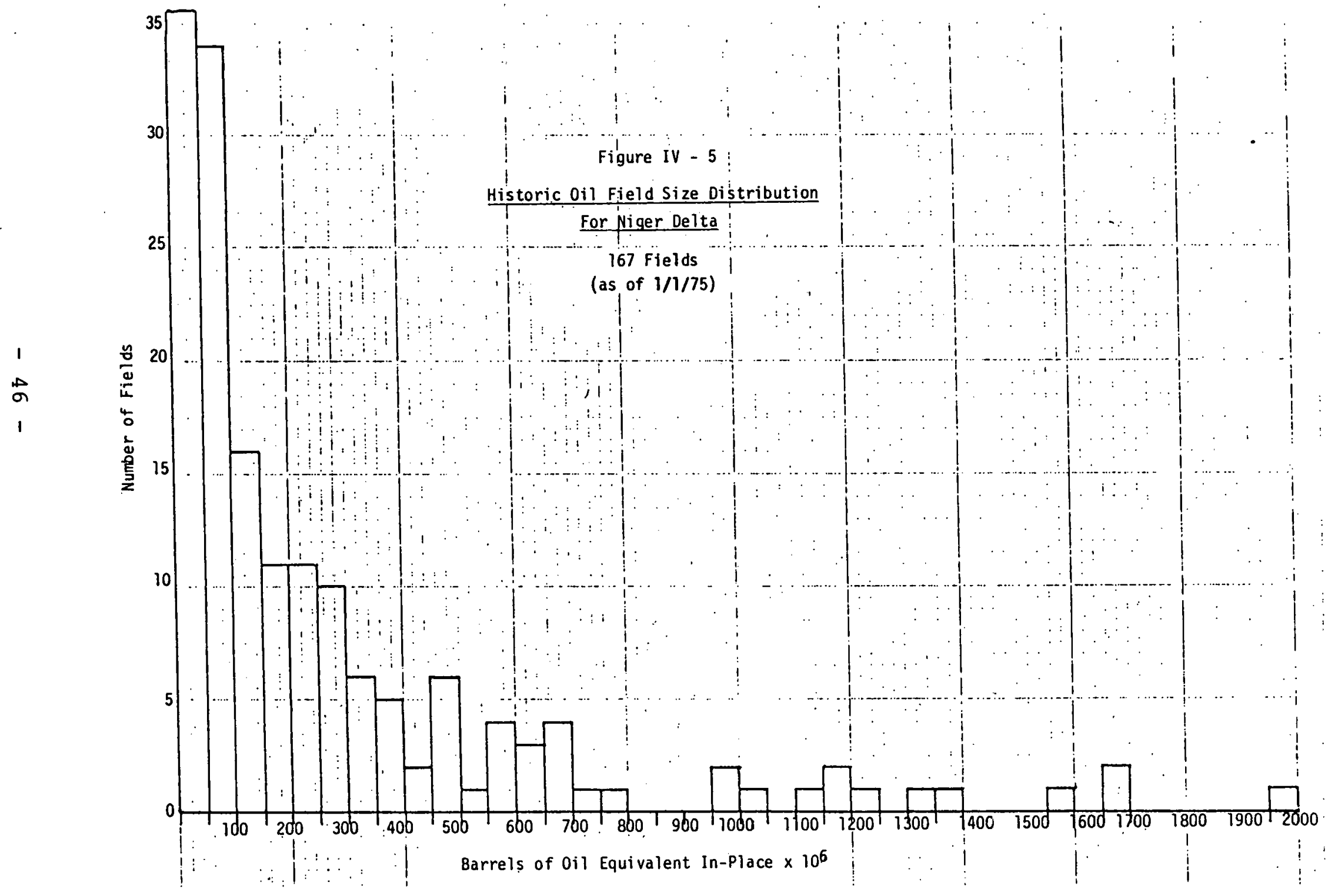


The relationship of the historic finding-rate of oil in the Niger Delta to future resource availability, using projected finding-rates, is shown in Figure IV-6.6/

The historic finding-rate is shown as a histogram depicting 7 increments of one-million feet of exploratory drilling through 1974.7/ Although another one million feet of exploratory drilling has been reported through 1977, the poor reporting of new field discoveries and the lack of information on the nature and amounts of these discoveries, make is inadvisable at this time to use these most recent data.

The method of projecting the future finding-rates based upon the historic data is as follows:

-- A "best fit" approach is taken in the search for a curve to be fitted to the historical data such that the displacement between the observed data points and the fitted line would be a minimum. The "best fit" for the historical finding-rate in the Niger Delta is the exponential decline curve of the form: $\mathrm{Y}=\mathrm{Ae} \mathrm{BX}^{\mathrm{BX}}$.

-- The curve which "best fits" the historical data is the projected mean finding-rate for a limited time projection. Confidence-limits on the projected finding-rates are set for the 95 percent and the 5 percent levels. The confidence-limits, or confidence-region, is bounded by the minimum and maximum findingrates. The confidence-limits on the regression line may be described by the "envelop" or the "bundle" of curves which gives an entire

6/ The Petroconsultants, S.A. "World Field Files" provide the data on the quantities and timing of discoveries.

7/ The data on the exploratory footage drilled by: year were taken from Schatzl (1969) and the Annual October AAPG Bulletin, "Foreign Development." 


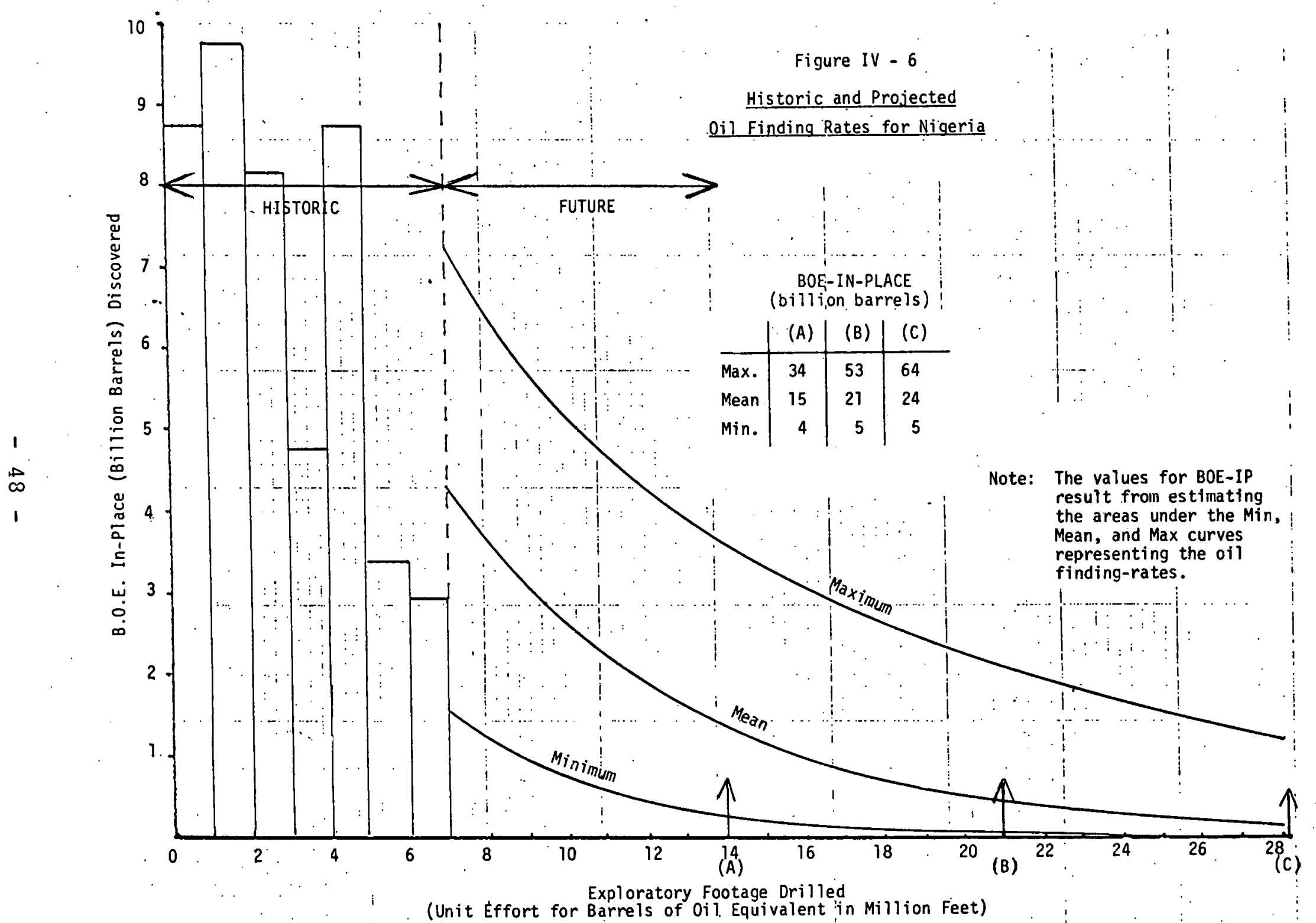

(Unit Effort for Barrels of Oil. Equivalent 'in Million Feet) 
spectrum of confidence-levels ranging from 95 to 5 percent. A 95 percent confidence insures values equal to the minimum finding-rate, and with only a 5 percent confidence are the values assured to equal the maximum finding-rate.

Example readings on the historical finding-rate for Nigeria indicate that at the end of 2 million feet of cumulative exploratory drilling nearly 10 billion barrels of oil-equivalent in-place were discovered per one million exploratory feet drilled, whereas at the end of 7 million feet of cumulative exploration driling less than 3 billion barrels of oil-equivalent were being discovered per one million exploratory feet drilled. Projected readings for the future using the mean curve indicate that at the end of 12 million feet of cumulative exploratory arilling, approximately two billion barrels of oil will be found per one million exploratory feet; whereas, after 17 million feet of cumulative exploratory drilling, less than one billion barrels will be found per one million exploratory feet.

Resource appraisal estimates on the remaining potential oil to be discovered can be made by means of these finding-rate projections as follows:

Keep in mind the basic assumptions that control the finding-rate methods and make a series of assumptions regarding the amount of exploratory footage to be drilled in the future. For example, assume that another 7 million feet of exploratory drilling will be completed (Figure IV-6) -.. that is, assume that as much footage will be drilled. as was drilled through 1974 -- then an estimate of the amount of oil to be found at that level of effort can be calculated for the minimum, mean, and maximum drilling rate.

-- For 14 million feet of cumulative exploratory drilling:

-- a minimum of an additional 4 billion barrels of oil equivalent in-place (BOE-IP):

-- a mean of an additional 15 billion barrels (BOE-IP); and, 
-- a maximum of an additional 34 billion barrels (BOE-IP).

-- Double the 14 million feet, or 28 million feet cumulative exploratory drilling:

-- a minimum of an additional 5 billion barrels (BOE-IP);

-- a mean of an additional 24 billion barrels (BOE-IPO; and,

-- a maximum of an additional 64 billion barrels (BOE-IP).

The resource appraisal results by this method are compared with the results obtained by other resource analysis methods.

Basic Statistical Data for the Niger Delta

The following statistical data compiled on the Niger Delta are pertinent for resource appraisal:

-- The area of the Niger Delta considered as a potential petroleum province is approximately 40,162 square miles;

-- The estimated volume of sediments in the Niger Delta;

-- 120,046 cubic miles (Hosper, 1967),

-- maximum volume 185,500 cubic miles (calculated with maximum thickness estimates of 3.97 miles, from Hosper, 1965).

-- Estimated distance from coastline to upper edge of continental slope, 46.6 miles;

-- Data extracted from an enlargement of a map (scale 1:500,000) (from Evamy et al, 1978); 
-- the area of the "main hydrocarbon belts" totals 16,200 square miles; and,

-- total area of known "rollover" anticlines is 6,844 square miles.

-- Total known oil in-place for the Delta as of January 1, 1975: $366,220 \mathrm{bbls} / \mathrm{cubic}$ mile. of sediment (based upon an estimated 43.964 billion barrels in-place and 120,048 cubic miles, from Hosper, 1965);

- The average number of pays reported within a field is 24; at the 95 percent level, 3 pays; and at the 5 percent level, 83 pays; when fitting a lognormal curve through the frequency distribution of number of pays per field, as shown in Figure IV-7; and,

-- Approximately 50 percent of the known "rollover" anticlines contain fields, an additional 23 percent of the known "rollover" anticlines contain oil and/or gas shows.

$\underline{\text { Resource Appraisal by Geological Analysis }}$

Resource appraisals made by means of a detailed geologic analysis of the province under study depend upon the following basic procedures:

-- A complete analysis of all the available geological and geophysical data by geologic province, i.e., Niger Delta; $\underline{8}$

-- A compilation of all the exploration statistics and all the available field data; and,

8/ The basic source of these data for Nigeria consisted of approximately 50 or more published references. The most significant sources of data ate listed in the Bibliography. 


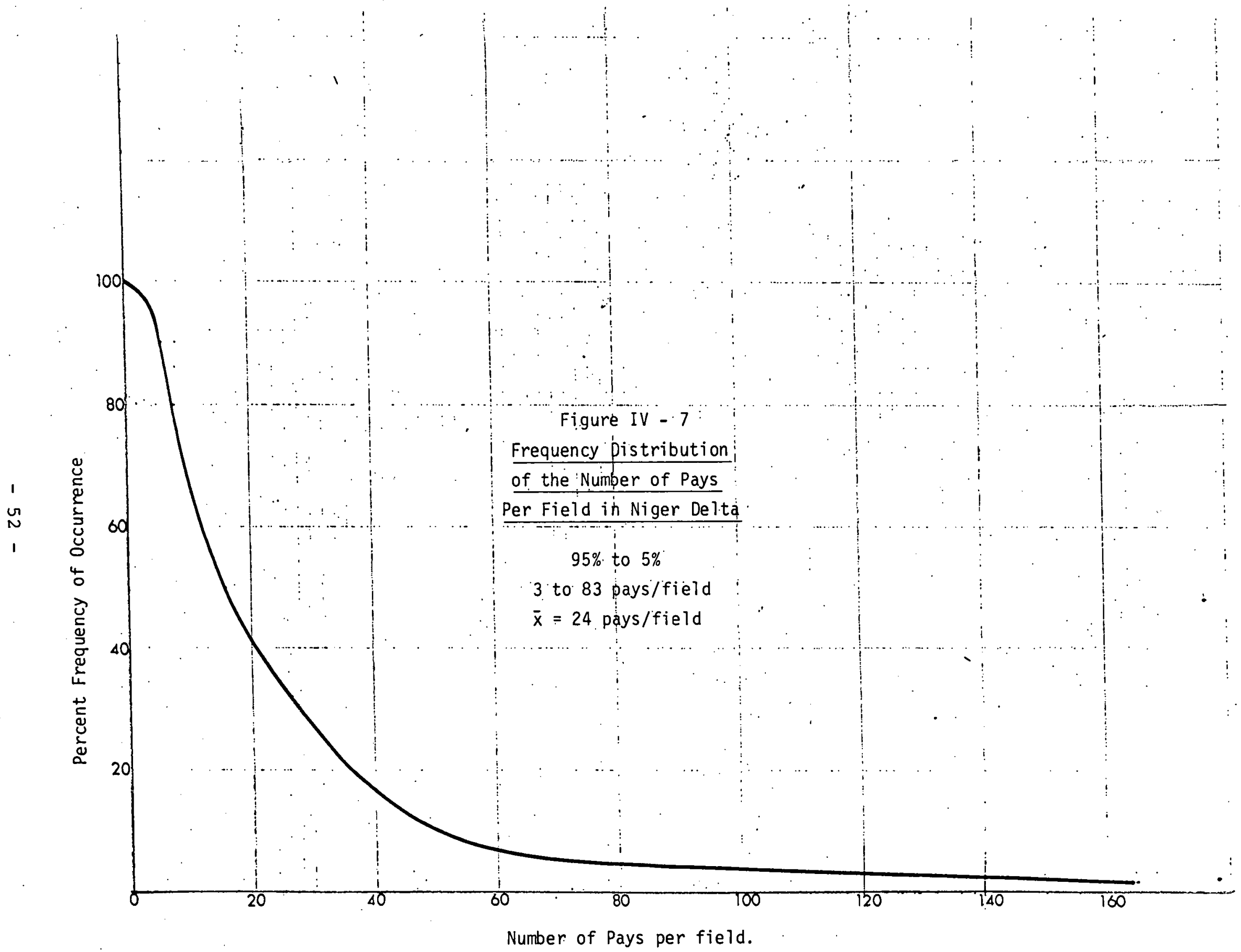


-- The application of at least two or more resource appraisal techniques for the assessment of the oil and gas resources as a means of cross-checking and verifying within reason the resource estimates.

Estimates of Remaining Oil Resources Using Various Methods

Volumetric 'yield' by province:

In the Delta, the known in-place estimate of the amount of oil per cubic mile of sediment is 366,220 barrels per cubic mile based upon exploration in 1965, for an estimated volume of 120,048 cubic miles (Hosper, 1965) in the Delta. Assuming further an additional 65,452 cubic miles of prospective sediments to be explored $(65,452$ cubic miles $x 366,220$ bbls/cubic miles), there remains to be found an average of approximately 24 billion barrels of oil equivalent in-place.

Volumetric 'yield' by productive hydrocarbon belts:

Using an average of 24 pays per field with thickness of less than 50 feet per pay, the amount of known oil in-place for the total hydrocarbon belts is approximately 12 million barrels in-place per cubic mile of producing sediment.

Assuming some optimum geologic conditions occurring in a fairly limited arcuate pattern offshore, with increasing pay thicknesses, but fewer numbers of pays due to the spacing and nature of the growth faulting, and noting the increasing potential for gas over the oil potential in these structures--the following resource estimates were made:

-- Assume an area equivalent to approximately 70 percent of the most productive hydrocarbon belt onshore, i.e., 11,600 square miles and a pay thickness of approximately 150 feet with 16 pays (50 percentile on frequency distribution for number of pays), or 2,400 feet of gross pay section. The 5,220 cubic miles of productive gross oil pay with 12 million barrels in-place per cubic mile of sediment would yield 62.6 billion barrels of oil resources in-place. 
Grid-Average Method:

The original oil in-place in the known onshore oil fields is disaggregated on the basis of the location of the fields within 30-minute latitude and longitude grids. Estimating a total proportional remaining oil resource for each grid, a resource estimate of 26.16 billion barrels of oil in-place remaining to be found was made. This method, however, does not. cover the undrilled offshore areas.

Final Resource Appraisals for Oil Using Subjective Probability Methods

Using all of the described methods and analyzing the results of these appraisals and the results of the finding-rate methods described earlier as scaling factors, the final resource estimates were made for the Niger Delta using subjective probability procedures as described in USGS Circular 725.9/

The resource appraisal estimates for the remaining undiscovered oil in-place in the Niger Delta as of January 1, 1978, are as shown in Table IV-2.

9/ Miller, B., et al., U.S. Geological Survey Circular 725, Department of the Interior. 
Table IV-2

Probability Levels

Remaining Undiscovered Oil

(Billion barrels)

\begin{tabular}{|c|c|c|c|}
\hline & $\begin{array}{l}\text { Probability } \\
\text { 95\% }\end{array}$ & $\begin{array}{c}\text { Probability } \\
5 \%\end{array}$ & $\begin{array}{c}\text { Mean } \\
\text { Estimate }\end{array}$ \\
\hline $\begin{array}{c}\text { Oil } \\
\text { In-Place }\end{array}$ & at least 5 & at least 65 & 24 \\
\hline $\begin{array}{l}---\overline{-}- \\
\text { Recoverable } \\
35 \% \text { R.F.* }\end{array}$ & $-\bar{y} \overline{l e a s t} \overline{1} . \overline{8}$ & $-\overline{-}-\overline{-}-\overline{2}-\overline{8}$ & $-\overline{:}-\overline{8.4}-$ \\
\hline
\end{tabular}

* Recovery factor.

In general, the quantity of oil in-place that may be extracted or produced from a reservoir may range from as little as 10 percent to as much as 50 percent. The recovery percentage (factor) is a function of the reservoir's physical characteristics, the drive mechanism. which forces the oil to flow from the reservoir into the well bore, and the reservoir pressure. These parameters, among others, determine the quantity of oil in-place that can be produced. Nigeria's recovery factor is estimated to be 35 percent during the primary production cycle.

Figure IV-8 depicts the lognormal probability distribution of the remaining undiscovered oil in-place resources in billions of barrels. 


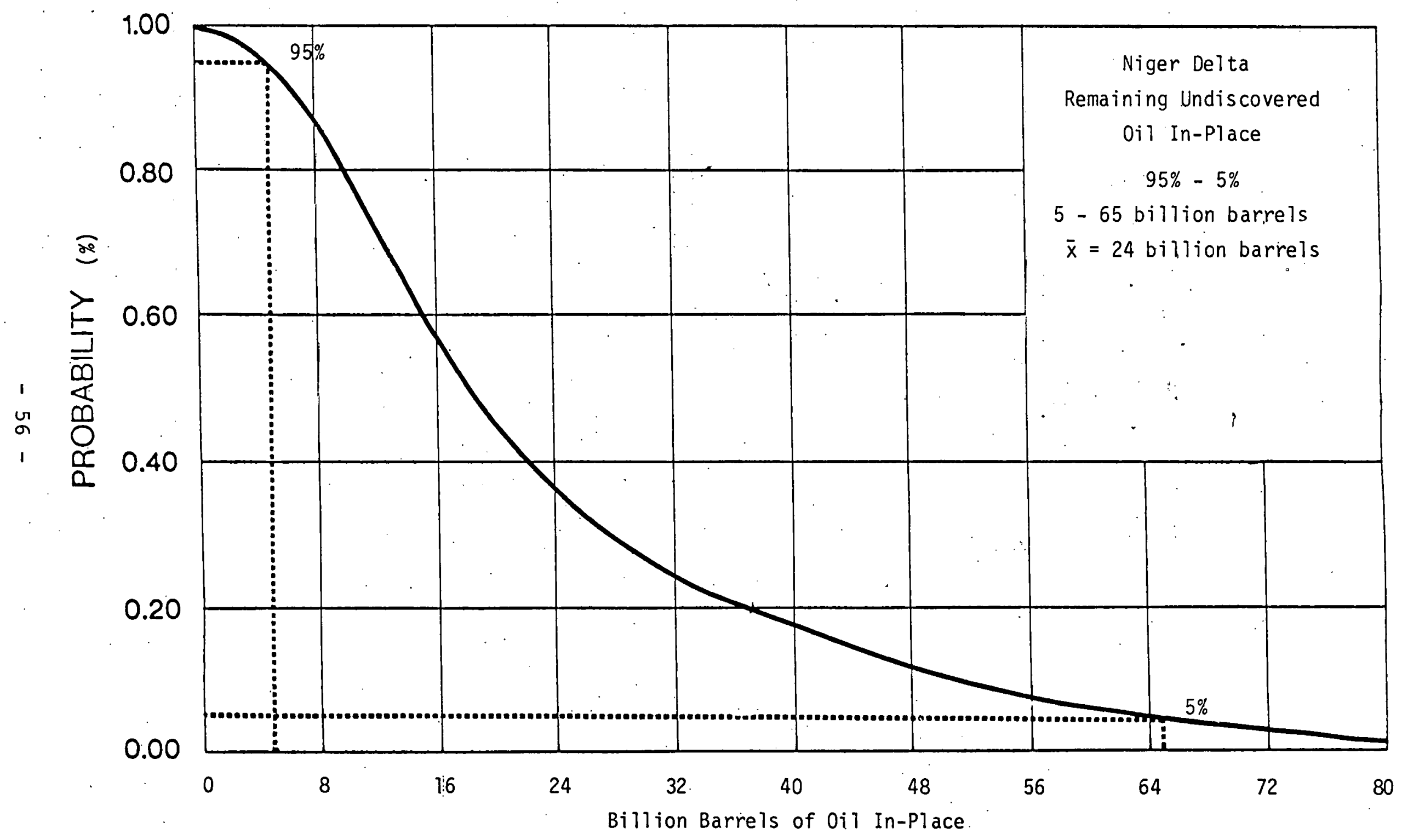

Figure IV - 8. Probability distribution of the Remaining Undiscovered 0 il In-P.lace Resources. 
Resource Appraisals for Natural Gas

The gas industry in Nigeria has remained relatively underdeveloped and even neglected. The proportion of gas associated with crude oil is relatively high in Nigeria. The gas-to-oil ratio averages 150 cubic meters per cubic meter of crude oil, or roughly 800 cubic feet per barrel of crude.

Although Nigeria may possess great natural gas potential and annually produces billions of cubic feet of associated gases from oil fields, only a small percentage of that produced is utilized.

Although specific data on gas fields are lacking, the occurrence and distribution of natural gas throughout the Delta is summarized briefly and has been considered in estimating the remaining undiscovered gas resources.

-- South of the main hydrocarbon-rich belt (SE-NW) is a series of narrow oil-rich zones; otherwise, a predominantly gas province occupies a fairly wide part of the central Delta;

-- In a given microstructure, the gas-to-oil ratio increases down plunge and in a generally seaward direction;

-- The more downdip a macrostructure is within a megastructure, the greater the probability of a higher gas-to-oil ratio; and,

-- Gas potential appears to increase seaward in the deeper sediments and in a southeasterly direction across the Delta. 
Using basically volumetric-yield analogs for the Niger Delta, a preliminary estimate of remaining undiscovered natural gas resources is made, as shown in Table IV-3.

$$
\text { Table IV-3 }
$$

Probability Levels

Remaining Undiscovered Gas

(Trillion cubic feet)

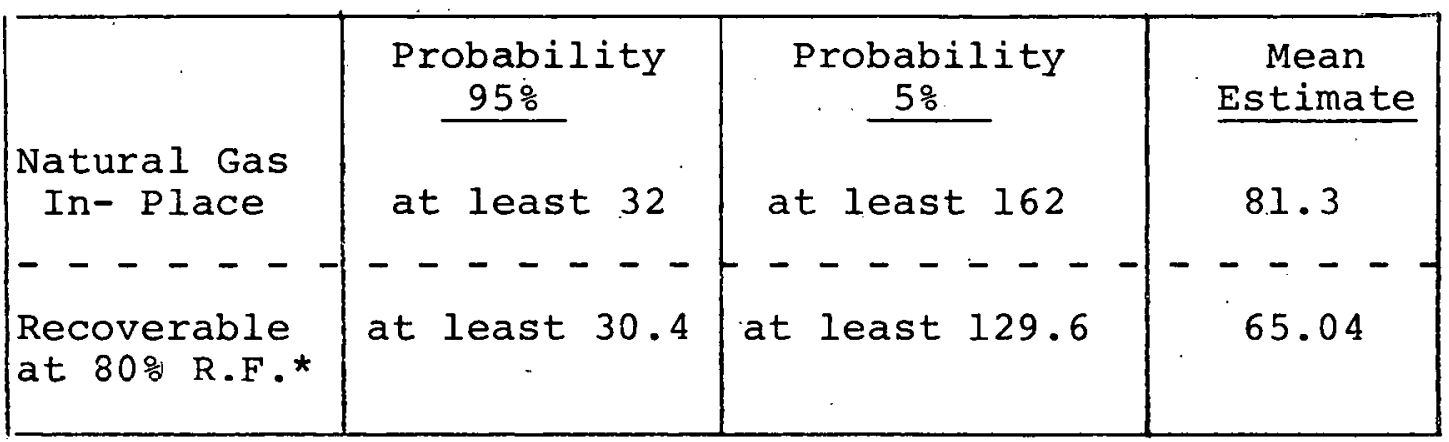

* Recovery factor. Recovery factor for natural gas is considered greater than it is for crude oil because of the inherent flow characteristic of gases vis-a-vis viscous liquids.

Figure IV-9 depicts the lognormal probability distribution of the remaining undiscovered gás in-place resources in trillions of cubic feet. 


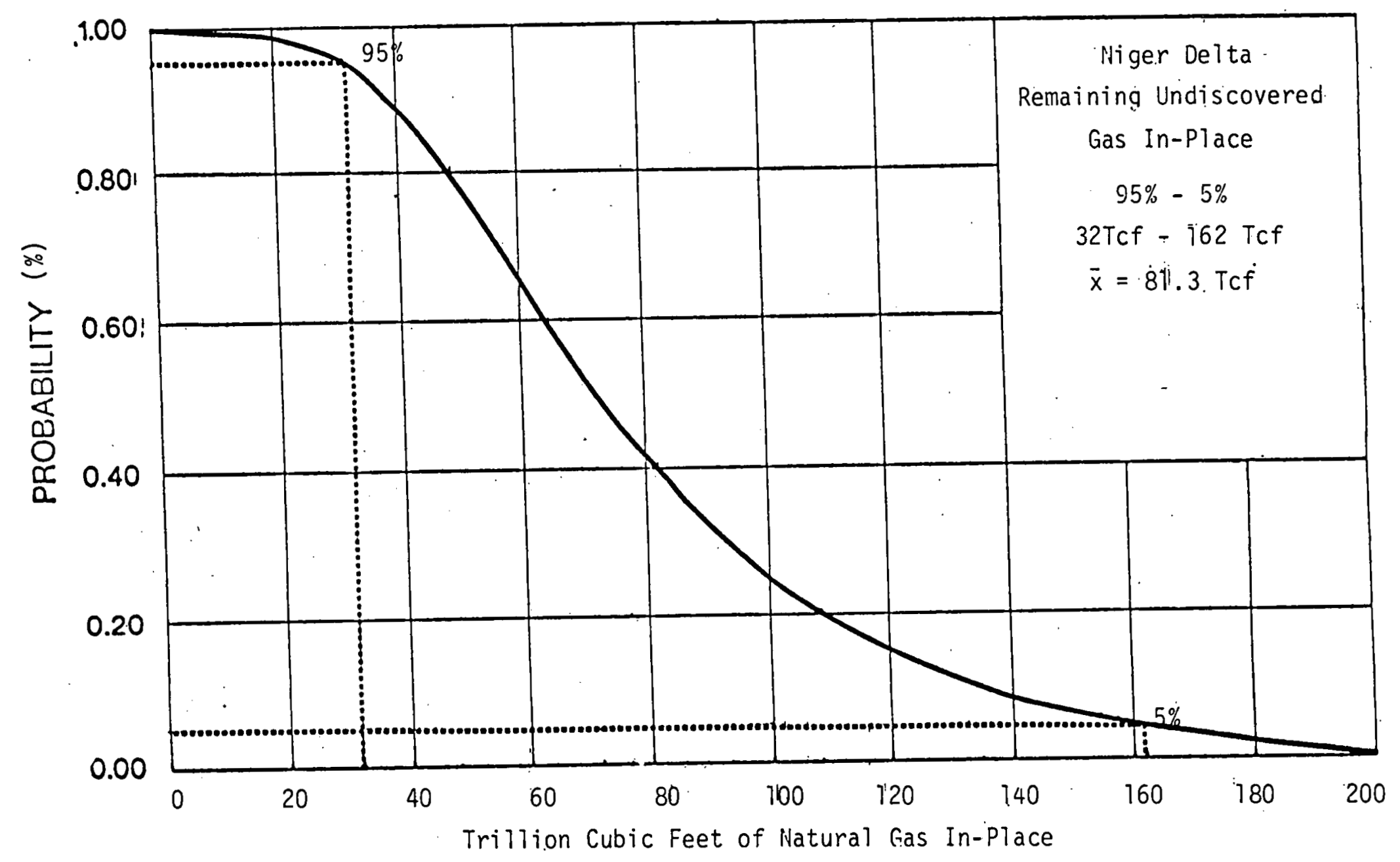

Figure IV-9 Probability distribution of the Remaining Undiscovered Gas In-Place Resources. 
Estimates of oil Field Sizes and Numbers for Remaining Undiscovered Resources

A mathematical technique is used to determine the probably sizes and numbers of the remaining undiscovered oil fields.

The following data are used for each series of estimates:

- Assume the field size distribution is lognormal based upon the historic information;

-- Given the minimum (95\%) and maximum (5\%) fields sizes ( $W .95$ to $W .05$ ) to be discovered under the conditions determined by the resource appraisal estimate; and

-- Given T: toal amounts of remaining undiscovered oil resources in-place in all future fields are shown in Table IV-4.

Table IV-4

Resource Estimates Disaggregated by Future Field size Range and Number

\begin{tabular}{|c|c|c|c|c|}
\hline $\begin{array}{l}\text { Resource } \\
\text { Appraisal } \\
(\mathrm{T})\end{array}$ & $\begin{array}{r}M j \\
\text { bar,re } \\
\text { W } .95\end{array}$ & $\begin{array}{l}\text { lions } \\
\text { S.in } \\
\text { W. } 05\end{array}$ & $\begin{array}{l}\text { of } \\
w_{\bar{x}}\end{array}$ & $\begin{array}{l}\text { Number of } \\
\text { Fields } \\
\text { (N) }\end{array}$ \\
\hline $\begin{array}{c}95 \%-5 \text { billion } \\
\text { barrels }\end{array}$ & 5 & 975 & 252 & 20 \\
\hline $\begin{array}{c}\overline{\mathrm{x}} \\
-24 \text { billion } \\
\text { barrels }\end{array}$ & 4.75 & 1200 & 310 & 77 \\
\hline $\begin{array}{c}5 \%-65 \text { billion } \\
\text { barrels }\end{array}$ & 4.5 & 2000 & 528 & 123 \\
\hline
\end{tabular}


The estimated field sizes as measured by oil in-place are shown in Table IV-5. .

Table IV-5

Disaggregated Field Sizes

(Million barrels of oil in-place)

\begin{tabular}{|c|c|c|c|c|c|c|c|c|c|}
$\begin{array}{c}\text { Percent } \\
\text { Probability }\end{array}$ & $\begin{array}{r}\text { No. of } \\
\text {-fields }\end{array}$ & $\begin{array}{r}0- \\
300\end{array}$ & $\begin{array}{r}300- \\
600\end{array}$ & $\begin{array}{r}600- \\
900\end{array}$ & $\begin{array}{r}900- \\
1200\end{array}$ & $\begin{array}{r}1200- \\
1500\end{array}$ & $\begin{array}{r}1500- \\
1800\end{array}$ & $\begin{array}{r}1800- \\
2100\end{array}$ & 1200 \\
\hline 95 & 20 & 16 & 2 & 1 & 1 & 0 & 0 & 0 & 0 \\
$\overline{\mathrm{x}}$ & 77 & 62 & 7 & 2 & 2 & 2 & 1 & 1 & 0 \\
5 & 123 & 86 & 16 & 9 & 4 & 2 & 2 & 2 & 2 \\
\hline
\end{tabular}

The estimated number of fields awaiting discovery by size of less than 300 million barrels of oil in-place Is $\equiv$ shown in Table IV-6.

Table IV-6

Estimated Number of Small and Intermediate Size Fields (Million barrels of oil in-place)

\begin{tabular}{|c|c|c|c|c|c|c|}
$\begin{array}{c}\text { Percent } \\
\text { Probability }\end{array}$ & $0-50$ & $\begin{array}{r}50- \\
100\end{array}$ & $\begin{array}{r}100- \\
150\end{array}$ & $\begin{array}{r}150- \\
200\end{array}$ & $\begin{array}{r}200- \\
250\end{array}$ & $\begin{array}{r}250- \\
300\end{array}$ \\
\hline 95 & 9 & 3 & 2 & 1 & 1 & 0 \\
$\overline{\mathrm{x}}$ & 32 & 11 & 8 & 4 & 4 & 3 \\
5 & 47 & 15 & 8 & 7 & 5 & 4 \\
\hline
\end{tabular}


The estimated number of fields to be discovered which have more than 300 million barrels of oil in-place is shown in Table IV-7.

Table IV-7

Estimated Number of Large Fields

(Milion barrels of oil in-place)

\begin{tabular}{|c|c|c|c|}
$\begin{array}{c}\text { Percent } \\
\text { Probability }\end{array}$ & $300-400$ & $400-500$ & $500-600$ \\
\hline 95 & 1 & 1 & 0 \\
$\overline{\mathrm{x}}$ & 3 & 2 & 2 \\
5 & 10 & 4 & 2 \\
\hline
\end{tabular}




\section{APPENDICES}

\section{APPENDIX A}

A. 1

Analysis Report: Nigeria An Assessment of Crude Oil Potential

$\underline{\text { APPENDIX B }}$

B. 1

Petroleum Geology of the Niger Delta

\section{$\underline{\text { APPENDIX C }}$ \\ Geologic Time Scale \\ Definitions \\ References}

C. 1

\section{APPENDIX D}

D. 1

Statistical Data: Historical Resume of oil Field production 
APPENDIX A

ANALYSIS REPORT

NIGERIA - AN ASSESSMENT OF CRUDE OIL POTENTIAL

Prepared by

William D. Dietzman

John H. Wood

Dallas Field office

Henry S. Weigel

Office of Integrative Analysis

Assistant Administrator for Applied Analysis Energy Information Administration

$$
\text { July } 31,1979
$$

This report was prepared in the DOE Energy Information Administration, Assistant Administrator for Applied Analysis, Office of Integrative Analysis, for the DOE Foreign Energy Supply Assessment Program. 


\section{ABSTRACT}

This paper presents estimates of the future oil supply capability of the country of Nigeria, the second largest exporter of crude oil to the United STates. Presented here are estimates of (1) original oil in place in known fields; (2) ultimate recovery from known fields; (3) remaining reserves in known fields; (4) U.S. Geological Survey estimates of total undiscovered oil resource potential for Nigeria; (5) undiscovered recoverable oil; and (6) projected supply patterns for the production of Nigerian oil over time.

As of January 1, 1976, there were 169 known fields that originally contained 44.2 billion barrels of $0 i 1$ and had an estimated remaining proved reserve of 12.3 billion barrels. However, by 1978, proved reserves were reported to be 12.6 billion barrels with the addition of new discoveries and development drilling during the two-year period. Cumulative production to January 1, 1978, was 6.1 billion barrels for a total ultimate oil recovery of 18.7 billion barrels from known fields.

The USGS estimated that undiscovered original oil in place at the 5 and 95 percent probability levels were 65 and 5 billion barrels, respectively, with a mean value of 24 billion barrels at the 38 percent probability level. It is estimated that 35 percent of this undiscovered oil could be recovered.

Using the mean value of 8.4 billion barrels of undiscovered recoverable oil results in an estimated total ultimate recovery of 27.7 billion barrels. From this resource base it is estimated that Nigeria could produce at a rate as high as 3.3 million barrels of oil per day which might occur as early as 1984 , providing there are no political or oil market restraints and there is a continuing successful exploration and development program in the country. Also, Nigeria could sustain 2 million barrels of oil per day (MM bpod) production to 1996, 2.4 MM bopd to. 1991, or 3 MM bopd to 1987 under the stated conditions.

other estimates of the ultimate recoveries at different probability levels and production of Nigerian oil over time at different probability levels are presented in the text.

A detailed discussion of the methodology used is also presented. In this study oil supply is limited to conventional production recoverable by drilling and secondary recovery but excludes enhanced oil recovery as well as other occurrences such as shale oil, etc. The analysis of production profiles is limited to a simple time series approach and is not subjected to explicit economic considerations. 


\section{CONTENTS}

Page

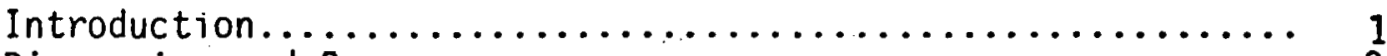

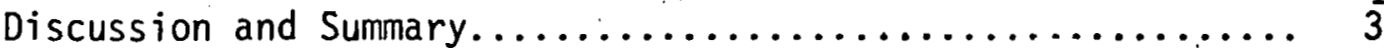

$0 i 1$ reserves and original oil in place................ 3

Resource appraisal........................... 3

Undiscovered recoverable resources................. 4

U7timate recovery........................... 4

Maximum oil production capability................. 5

Alternate production schedules.................... 7

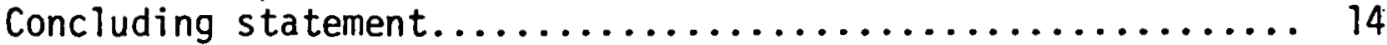

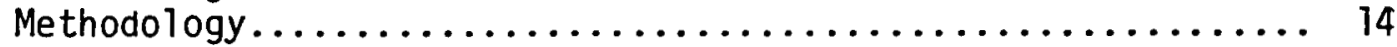

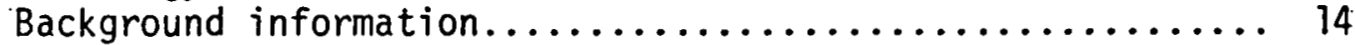

$0 i 1$ recovery estimating procedures for Nigeria.......... 15

$0 i 1$ reserves and original oil in place................ 16

Potential oil reserves from secondary recovery........... 16

Data sources and reserves comparison.............. 17

Range of possible production capability profiles......... 18

Production capability schedule - standard

logistic equation......................... 21

Production capability schedule - modified

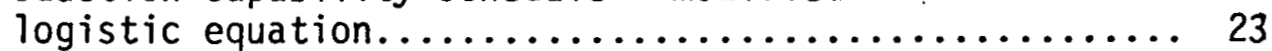

ATternate production schedules.................. 26

\section{ILLUSTRATIONS}

Fig.

1. Sensitivity of maximum production capability profiles.. 6

2. Historical and projected production profiles based upon the mean ultimate recovery................ 9

3. Historical and projected crude oil production for five ultimate recoveries (case 1 - 2 MM bopd)....... 10

4. Historical and projected crude oil production for five ultimate recoveries (case $2-2.5 \mathrm{MM}$ bopd).... 11

5. Historical and projected crude oil production for five ultimate recoveries (case 3 - 3 MM bopd)...... 12

6. Maximum production capability profiles using mean ultimate recovery $\left(27.1 \times 10^{9} \mathrm{bbl}\right)$ for Nigeria..... 22

\section{TABLES}

1. Alternate production schedules for Nigeria.......... 13 
INTRODUCTION

It is the general concensus that the United States will be strongly dependent in the future on foreign energy sources. In 1978, the Foreign Energy Supply Assessment Program (FESAP); was initiated within the Department of Energy (DOE), to assess the future supply capabilities of several oil exporting countries. FESAP is conducted under the supervision of the Foreign Energy Supply Assessment Committee (FESAC), consisting of representatives from the Energy Information Administration (EIA), the Office of International Affairs, the Office of Policy and Evaluation, and the Office of Resource Applications, DOE, and the United States Geological Survey (USGS), Department of the Interior (DOI).

The specific objectives of FESAP are to:

1. Develop projections of foreign oil and gas production capacities for key producing countries based on the analys is of current geological and engineering data.

2. Forecast long-term availability of oil and gas supplies from key producing countries, based on analysis of the petroleum resource base, reserves, and depletion rates.

3. Apply the skills and techniques developed in achieving the objectives of (1) and (2) above, to other foreign energy resources.

Within the past two decades, Nigeria's Niger Delta has become a major oil producing province and the country has become the second largest exporter of crude oil to the United States. In late 1978, a working group from EIA and the USGS was formed to assess Nigeria's future crude oil supply capability on a pilot basis. This study is the first systematic assessment of this type conducted by the U.S. Government of a foreign country and will serve as a prototype for other nations.

The assessment of Nigeria's future oil supply capability requires several interdependent analytical procedures. First, the original oil in place (0OIP) and reserves in known fields are determined. These data are used to assess the undiscovered resources as 00IP and that portion of the 00IP that may be recoverable. These data are used to estimate the total ultimate oil recovery for the country from which projected production capability schedules are determined.

It was the EIA's responsibility to estimate the proved reserves, ultimate recovery and resource base (00IP) for known fields and develop the maximum production capability methodology and long-term supply capability. The USGS's task was to estimate the undiscovered oil and gas resource base. It is the purpose of this report to present the EIA's findings for Nigeria. 
In this report oil supply is limited to conventional production recoverable by drilling and secondary recovery, but excludes enhanced oil recovery as well as other occurrences such as shale oil and tar sands. Future discoveries and the production from those new fields are considered in this analysis as well as that from currently known fields. The resource appraisal methods and results that were input to this study were limited to the following considerations. These methods:

(1) are to be applied directly only to semi-mature or maturely drilled producing areas,

(2) are to be applied to an area of fairly fixed boundaries (sample size must not change radically), and

(3) do not allow for any radical "surprises" in petroleum exploration or significant "improvements" in exploration technology or economics.

In this study an analysis of production profiles is presented. The modeling employed is limited to a simple time series approach and is not subjected to explicit economic considerations. The timing of future discoveries, ultimate recovery estimates, and time profiles of production all depend on the relative economics of drilling and related markets as well as the effects of indigenous and foreign demand. Future, institutional, infrastructure and behavioral factors were subjectively evaluated but are not explicitly represented in the model. 


\section{DISCUSSION AND SUMMARY}

The assessment of Nigeria's crude oil reserves, ultimate recovery and OOIP in known fields and maximum production capability was begun in October, 1978. Results obtained are discussed here in chronological order as each task was accomplished and a detailed explanation of the methodology is presented in succeeding sections of the report. Also presented are alternate production profiles developed for the country as well as the sensitivity of the maximum oil production capability model to ultimate recovery.

\section{0il Reserves and Original 0 il in Place}

The remaining crude oil reserves by field were estimated by EIA in order to estimate oil recovery factors and verify the estimates of remaining reserves reported in the literature. The remaining crude $0 i 1$ reserves of known fields in Nigeria are estimated to be $12.3 \times 10^{9}$ barrels as of January 1, 1976. This compares favorably to the 13.0 $\times 10^{9}$ barrels as of January 1., 1976, reported in the 1 iterature. The OOIP is calculated to be $44.2 \times 10^{9}$ barrels for known fields as of January 1, 1976. The OOIP data by field were submitted to the USGS's Resource Appraisal Group (RAG), to be used as data input in their resource appraisal methods for undiscovered oil in place.

\section{Resource Appraisal}

RAG estimated the undiscovered oil resource (OOIP) for Nigeria by geologic analysis and basin evaluation techniques (1). These resource estimates are reported as continuous probability distribution curves from less than a 5 percent probability. to 100 percent probability level. These probability levels mean that there will be at least the associated volume of undiscovered 00IP occurring. The remaining undiscovered oil resources as of January 1, 1978, for five probability levels read from the curves are:

(1) A full explanation of the techniques used to estimate the undiscovered resources and the results obtained will be published by USGS. 


\begin{tabular}{lccccc}
\hline & \multicolumn{9}{c}{ Probability Levels } & & \\
\hline & 95 pct & 75 pct & 25 pct & 5 pct & Statistical \\
Remaining & at least & at least & at least & at least & at least \\
undiscovered & $5 \times 10^{9}$ & $11 \times 10^{9}$ & $31 \times 10^{9}$ & $65 \times 10^{9}$ & $24 \times 10^{9}$ \\
O0IP & bbl & bbl & bbl & bbl & bbl \\
\hline
\end{tabular}

*0ccurs at 38 percent probability level.

It should be noted that the above undiscovered resource estimates are for the Niger Delta basin and the offshore continental shelf only.

\section{Undiscovered Recoverable Resources}

The recovery factor determined by EIA on a field-by-field basis under current operating practice as of January 1, 1976, for known fields (excluding potential secondary reserves) averages 34.9 percent. Therefore; it is assumed that a recovery factor of 35 percent is applicable to the undiscovered oil resources, thereby giving the following undiscovered recoverable oil, providing, of course, all of the undiscovered resources at the different probability levels are found,

\begin{tabular}{|c|c|c|c|c|c|}
\hline \multirow{3}{*}{$\begin{array}{l}\text { Remaining } \\
\text { undiscovered } \\
\text { recoverabie } \\
\text { oil }\end{array}$} & \multicolumn{4}{|c|}{ Probability Levels } & \multirow[b]{2}{*}{$\begin{array}{c}\text { Statistical } \\
\text { mean* }\end{array}$} \\
\hline & $95 \mathrm{pct}$ & 75 pct & $25 \mathrm{pct}$ & $5 \mathrm{pct}$ & \\
\hline & $\begin{array}{c}\text { at least } \\
1.8 \times 10^{9} \\
\mathrm{bbl}\end{array}$ & $\begin{array}{c}\text { at least } \\
3.9 \times 10^{9} \\
\text { bbl }\end{array}$ & $\begin{array}{c}\text { at least } \\
10.9 \times 109 \\
\text { bbl }\end{array}$ & $\begin{array}{c}\text { at least } \\
22.8 \times 10^{9} \\
\text { bbl }\end{array}$ & $\begin{array}{l}\text { at least } \\
8.4 \times 10^{9} \\
\text { bb }\end{array}$ \\
\hline
\end{tabular}

*0ccurs at 38 percent probability level.

\section{Ultimate Recovery}

The ultimate recovery from known fields each year since production began in Nigeria in 1958 were required data for the methodologies employed in this study. These data were purchased by DOE and USGS to obtain a consistent series of data from a single source and were found to be reasonably accurate by making a point estimate as of January 1, 1976. The ultimate recovery volume from known fields as of January 1, 1978, was used (to correspond with RAG's appraisal completed as of January 1; 1978), to calculate total ul timate recovery. Ult imate recovery from known fields as of January 1,1978 , is $18.7 \times 10^{9}$ barrels, of which $6.1 \times 10^{9}$ barrels has been produced. Adding the estimated undiscovered recoverable oil at the different probability levels to that estimate for known fields results in the following estimated total ultimate oil recoveries for Nigeria. 


\begin{tabular}{lcccccc}
\hline & \multicolumn{7}{c}{ Probability Levels } \\
\hline & 95 pct & 75 pct & 25 pct & 5 pct & $\begin{array}{c}\text { Statistical } \\
\text { mean* }\end{array}$ \\
\cline { 2 - 7 } Ultimate & at least & at least & at least & at least & at least \\
oil & $20.5 \times 10^{9}$ & $22.6 \times 10^{9}$ & $29.6 \times 109$ & $41.5 \times 10^{9}$ & $27.1 \times 10^{9}$ \\
recovery & & bbl & bbl & bbl & bbl \\
\hline
\end{tabular}

*0ccurs at 38 percent probability level.

Maximum 0il Production Capability

The maximum oil production capability at any time is the maximum deliverability rate assuming that there are no political or oil market restraints. Actual production may be far less than the possible maximum. Nigerian production declined in 1975, increased in 1976 and 1977 to nearly 2.1 MM bopd and decreased to $1.9 \mathrm{MM}$ bopd in 1978. These average production rates resulted from specific government actions interacting with the world oil market. It is highly probable that Nigeria could have produced more oil than it did during these years. However, in January and February of 1979; the Government permitted an all-time high production rate of over $2.4 \mathrm{MM}$ bopd. The average daily production rates from 1960 through 1978 are plotted in figure 1.

The maximum production capability is projected by a mathematical model which utilizes a modified logistic function. This production capability is predicted to increase rapidly at first, slow with time, peak, and then begin declining until a limiting exponential decline rate is reached. This model will predict both the peak maximum production capability and the time of peak production, using an assumed ultimate recovery and a limiting exponential decline rate. For this assessment, the limiting exponential decline rate is assumed to be 10 percent per year, based on the assumption that after production decline begins, there will be sufficient exploration success and development activity to maintain an oil production decline rate that gradually approximates 10 percent per year. Considering the wide range of possible values for ul timate recovery, attention is focused on the statistical mean value of the estimated ultimate recovery to. illustrate the maximum production capability model.

Figure 1 shows the estimated maximum production capability profile (solid curve) for Nigeria with the ultimate recovery $\left(27.1 \times 10^{9}\right.$ barrels) calculated using the statistical mean value of undiscovered recoverable oil $\left(8.4 \times 10^{9}\right.$ barrels $)$. The curve peaks in 1984 with suggested maximum production capability of 3.3 MM bopd. 


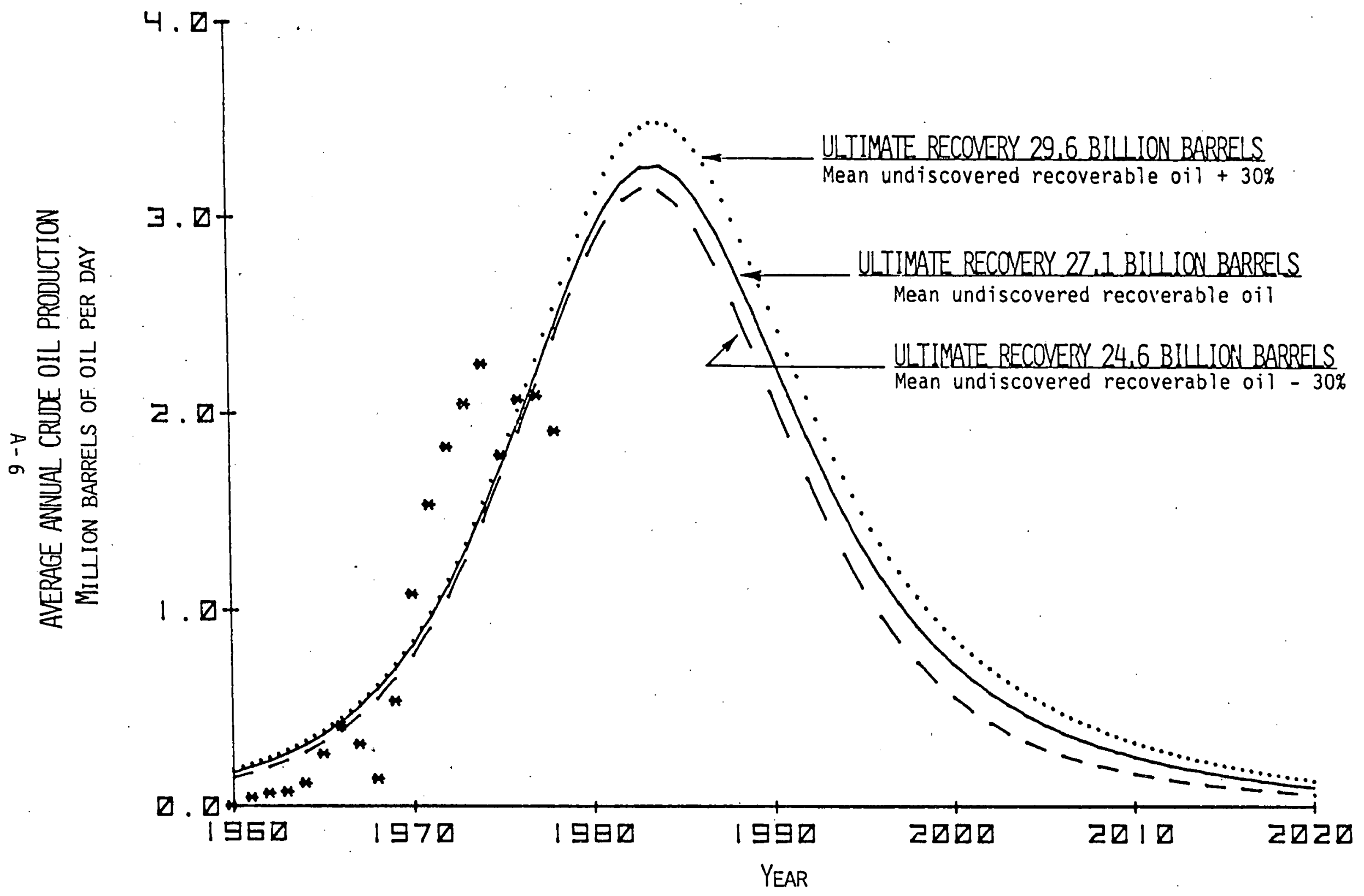

FIGURE 1. - Sensitivity of maximum production capability profiles. 
The behavior of the model with changes in ultimate recovery is tested by varying the mean undiscovered recoverable oil by plus and minus thirty percent of its value. The resulting higher and lower ultimate recoveries are 29.6 and $24.6 \times 10^{9}$ barrels compared to the estimated mean value of $27.1 \times 10^{9}$ barreis. These changes of five billion barrels of oil did not result in major changes for the estimated maximum production capability profile. The general result is that, if ultimate recoveries are lower or higher than the mean, production peaks earlier or later in time and at a lower or higher production rate.

The variation of plus or minus 30 percent of the undiscovered recoverable oil is used because it is a large enough quantity to adequately test the sensitivity of the maximum production capability model and brackets the 50 percentile probability level (median value) being 54 percent probability on the high side and 25 percent probability on the low side.

For u7timate recoveries of $24.6,27.1$ and $29.6 \times 10^{9}$ barrels, the estimated maximum production capabilities are $3.1,3.3$ and $3.5 \mathrm{MM}$ bopd respectively. The corresponding peak production years are 1983, 1984 and 1985 (the actual peak days of the three curves are separated by less than a year). Changing the mean value of the undiscovered recoverable oil by plus or minus 30 percent changes the estimated maximum production capability by plus or minus 6 percent. Therefore, the maximum production capability profiles are not highly sensitive to relacively large percentage changes in the mean value for undiscovered recoverable oil.

\section{Alternate Production Schedules}

Nigeria can control its level of oil production within limits determined by its ultimately recoverable oil through continuing exploration, state of development and the world oil market. One of the objectives of FESAP is to estimate Nigeria's long-term supply capability under various conditions, i.e., how long Nigeria can supply oil at a given level of production. For the purpose of illustrating long-range crude oil availability, three alternate production schedules are analyzed. These are:

Case 1 - Annual oil production increasing from the 1978 level of 1.9 MM bopd to 2.0 MM bopd in 1979 , constant production of $2.0 \mathrm{MM}$ bopd to the year oil production begins declining exponentially at 10 percent per year.

Case 2 - Annual oil production increasing from the 1978 level of $1.9 \mathrm{MM}$ bopd to 2.5 MM bopd in 1979, constant production of $2.5 \mathrm{MM}$ bopd to the year oil production begins declining exponentially at 10 percent per year; and 
Case 3 - Annual production increasing from the 1978 level of $1.9 \mathrm{MM}$ bopd to $3.0 \mathrm{MM}$ bopd in 1981 , constant production of $3.0 \mathrm{MM}$ bopd to the year oil production begins declining exponentially at 10 percent per year.

The oil production for all three cases are illustrated in figure 2 for the ultimate recovery of 27.1 billion barrels based upon the mean value for undiscovered recoverable oil. In the case of higher production rates, decline begins earlier and depletion occurs quicker. For constant production rates of 2, 2.5 and 3 MM bopd, production decline begins in 1996, 1991 and 1987, respectively. This represents a range of about 9 years (past 1987) for which some nearly constant rate of production between 2 and 3 MM bopd could be maintained. The above cases are only three of an infinite number of ways to schedule possible oil production up to the limit of $3.3 \mathrm{MM}$ bopd, given a mean ultimate recovery of 27.1 billion barrels.

Other values of ultimate recovery would change the predicted length of time that any given constant production rate might be maintained. The calculated production schedules for the five predicted ultimate recoveries are shown in figures 3,4 and 5 for the case 1,2 and 3 conditions, respectively ( $2,2.5$ and 3 MM bopd and 10 percent decline). For case 1 , shown in figure 3 , the years in which production decline begins are 1987, 1991, 1996, 2000 and 2016. The increases in constant production times are simply proportional to the predicted ultimate recovery for a given constant production rate. The 29-year range in time to nroduction decline reflects the large differences in estimated ultimate recovery associated with the probability levels of 5 and 95 percent. The range in time to production decline drops to 23 and 19 years for the higher constant production rates of 2.5 and $3 \mathrm{MM}$ bopd as shown in figures 4 and 5 . This results from producing a given amount of oil at a faster rate. Note in figure 5, if Nigeria should have only 20.5 billion barrels of ultimate recovery, a production rate of 3 MM bopd could not be maintained for a full year.

Each of the curves in figures 3,4 and 5 result from assuming a particular ultimate recovery which corresponds to a given probability level for the assessment of remaining undiscovered oil in place. For example, in figure 3, curve 1 corresponds to a 95 percent probability that there will be at least 5 billion barrels of undiscovered oil in place, 1.8 billion barrels of undiscovered recoverable oil (assuming a 35 percent recovery factor) for a total of 20.5 billion barrels of ultimate recovery. From these estimates it is highiy probable that a constant production rate of 2 MM bopd could be maintained at least until 1987 under the assumed conditions. Similarly, it is unlikely that a constant production rate of 2 MM bopd could be maintained past the year 2016, since there is only 1 chance in 20 that the ultimate oil recovery will exceed the 41.5 billion barrels predicted at the 5 percent probability level (curve 5). 
6. $-\forall$

AVERAGE ANNUAL CRUIUE OIL PRODUCTION

MILION BARRELS OF OIL PER DAY

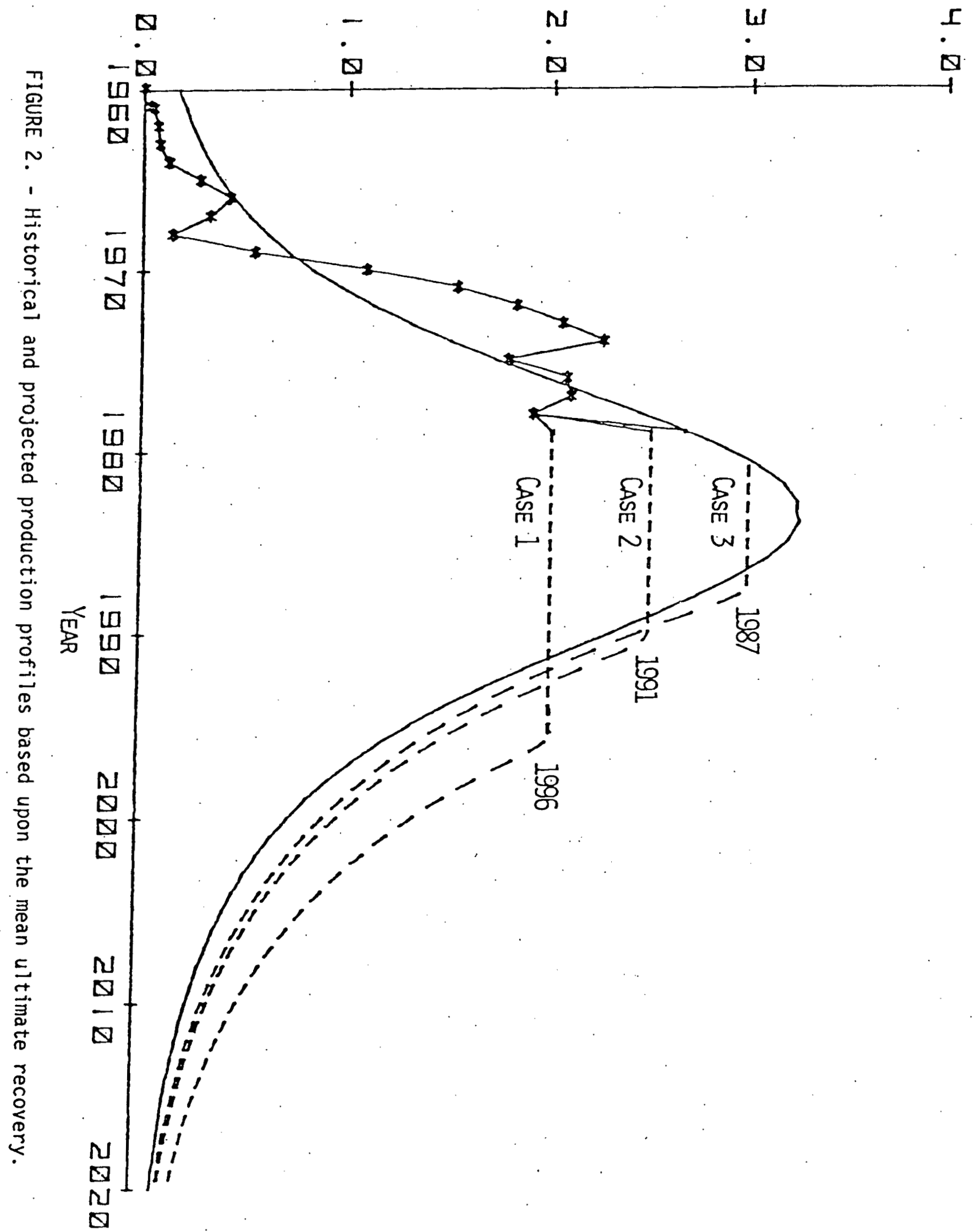




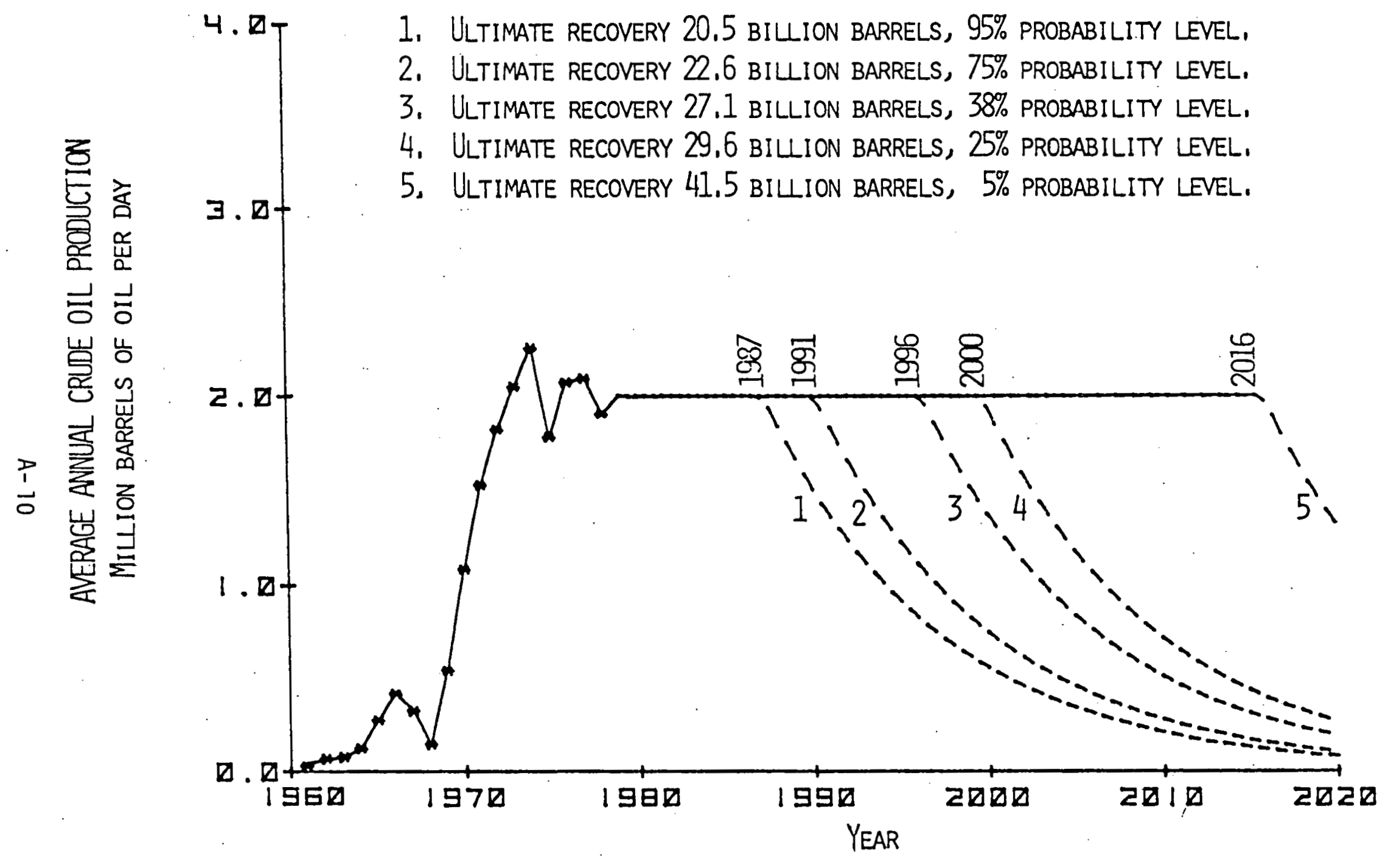

FIGURE 3. - Historical and projected crude oil production for five ultimate recoveries (Case $1-2$ MM bopd). 


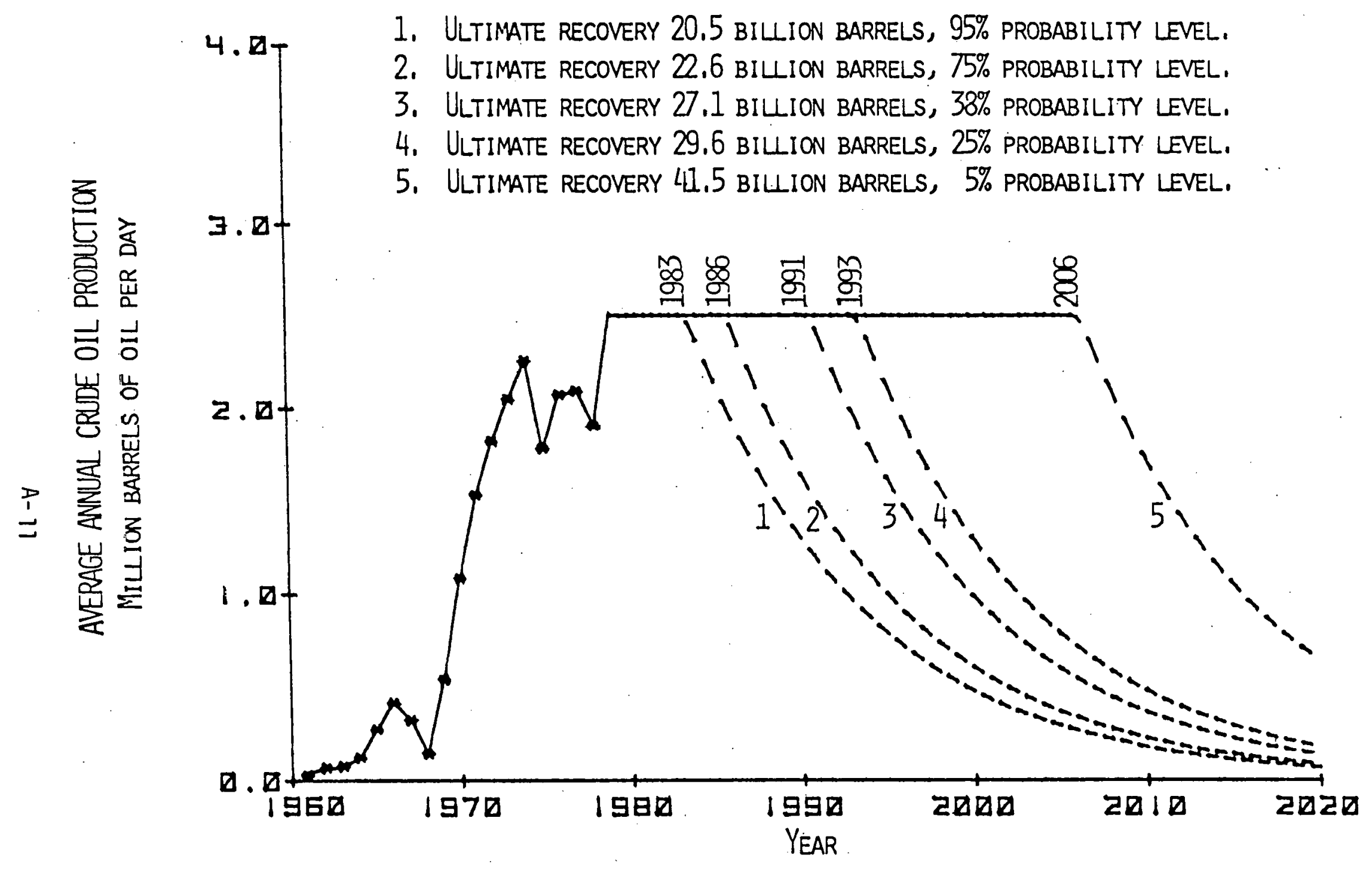

FIGURE 4. - Historical and projected crude oil production for five ultimate recoveries (Case $2-2.5$ MM bopd). 
1. ULTIMATE RECOVERY 20,5 BILION BARRELS, $95 \%$ PROBABILITY LEVEL,

2. ULTIMATE RECOVERY 22,6 BILLION BARRELS, $75 \%$ PROBABILITY LEVEL.

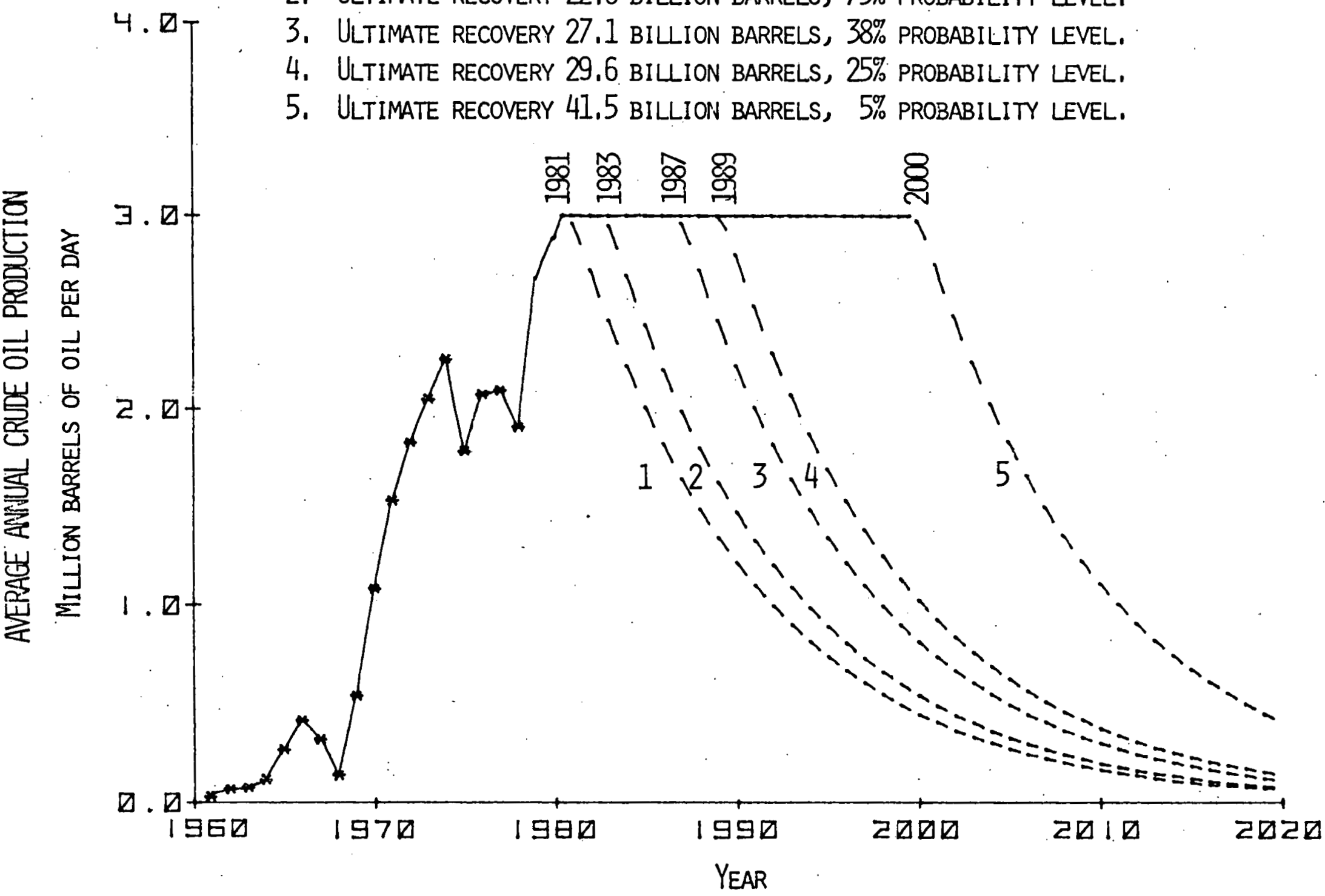

FIGURE 5. - Historical and projected crude oil production for five ultimate recoveries (Case $3-3$ MM bopd). 
This study presents a broad spectrum of possible alternate production schedules. For example, Nigeria may be able to produce $2.5 \mathrm{MM}$ bopd into the early 1980's, with a 5 percent probability of producing that amount beyond the year 2000, as depicted in figure 4 . It would be reasonable to assume that the actual time of constant production at the $2.5 \mathrm{MM}$ bopd level might be bracketed by the curves corresponding to the 75 and 25 percent probability values for Nigeria in curves 2 and 4 in figure 4 . The range in time to production decline for curves 2 and 4 is 7 years compared to 23 years for curves 1 and 5, corresponding to the 95 and 5 percent probability levels.

The estimated oil production by five-year intervals, the year oil production decline begins, and the year that the cumulative oil production equals. 95 percent of predicted ultimate recovery under the three production schedules for the five probability values of estimated ultimate recovery are shown in table 1.

TABLE 1. - Alternate Production Schedules for Nigeria

CASE 1 (2 MM bopd)

(Figure 3)

\begin{tabular}{|c|c|c|c|c|c|c|c|}
\hline \multirow{2}{*}{$\begin{array}{c}\text { Probability } \\
\text { levels, } \\
\text { percent }\end{array}$} & \multicolumn{5}{|c|}{ Million Barrels of 0 il Per Day } & \multirow{2}{*}{$\begin{array}{l}\text { Year } \\
\text { decl ine } \\
\text { begins }\end{array}$} & \multirow{2}{*}{$\begin{array}{c}\text { Year } \\
95 \text { pct } \\
\text { depleted }\end{array}$} \\
\hline & 1980 & 7985 & $\begin{array}{l}\text { YEAR } \\
1990\end{array}$ & 1995 & 2000 & & \\
\hline $\begin{array}{l}95 \\
75 \\
38 \text { (Mean) } \\
25 \\
5\end{array}$ & $\begin{array}{l}2.00 \\
2.00 \\
2.00 \\
2.00 \\
2.00 \\
\end{array}$ & $\begin{array}{l}2.00 \\
2.00 \\
2.00 \\
2.00 \\
2.00 \\
\end{array}$ & $\begin{array}{l}1.51 \\
1.84 \\
2.00 \\
2.00 \\
2.00 \\
\end{array}$ & $\begin{array}{l}0.92 \\
1.23 \\
2.00 \\
2.00 \\
2.00\end{array}$ & $\begin{array}{l}0.56 \\
0.75 \\
1.38 \\
1.86 \\
2.00\end{array}$ & $\begin{array}{l}1987 \\
1991 \\
1996 \\
2000 \\
2016 \\
\end{array}$ & $\begin{array}{l}2007 \\
2009 \\
2013 \\
2016 \\
2029 \\
\end{array}$ \\
\hline
\end{tabular}

CASE II (2.5 MM bopd)

(Figure 4)

\begin{tabular}{llllllll}
95 & 2.50 & 2.14 & 1.30 & 0.79 & 0.48 & 1983 & 2005 \\
75 & 2.50 & 2.50 & 1.65 & 1.00 & 0.61 & 1986 & 2007 \\
38 (Mean) & 2.50 & 2.50 & 2.50 & 1.63 & 0.99 & 1991 & 2010 \\
25 & 2.50 & 2.50 & 2.50 & 2.15 & 1.31 & 1993 & 2012 \\
5 & 2.50 & 2.50 & 2.50 & 2.50 & 2.50 & 2006 & 2021 \\
\hline
\end{tabular}

CASE III (3.0 MM bopd)

(Figure 5)

\begin{tabular}{llllllll}
\hline 95 & 2.90 & 2.10 & 1.28 & 0.77 & 0.47 & 1981 & 2005 \\
75 & 2.90 & 2.44 & 1.48 & 0.90 & 0.54 & 1983 & 2006 \\
38 (Mean) & 2.90 & 3.00 & 2.23 & 1.35 & 0.82 & 1987 & 2008 \\
25 & 2.90 & 3.00 & 2.81 & 1.70 & 1.03 & 1989 & 2009 \\
5 & 2.90 & 3.00 & 3.00 & 3.00 & 2.98 & 2000 & 2017 \\
\hline
\end{tabular}


It is concluded that enough basic technological information is available to assess the supply capability of many of the oil exporting nations. Therefore, it is recommended that the Foreign Energy Supply Assessment Program be continued in order to assess the world oil resource base and production capability. Because of the energy situation in the United States, it is extremely important to know the potential sources of crude oil and its future availability in the world market.

\section{METHODOLOGY}

The EIA's responsibility is to estimate the ultimate recovery, remaining reserves, and resource base for known fields. It is also EIA's responsibility to formulate methods for predicting maximum productive capability and for estimating the long-term supply capability of the country. Background information on methods used in estimating reserves, ultimate recovery, and 00IP is presented, as well as the procedures used in estimating these quantities for Nigeria. Also, a detailed discussion of the methods for predicting production capability are presented in the remainder of the report.

\section{Background Information}

Normally, 00IP, the ultimate recoverable production, and the reserv: $s$ as of a specific date for a known field or reservoir are determined by orie of the four following methods:

- Volumetric,

- material balance,

- performance, and

- nominal.

The volumetric estimate is commonly used during the early life of the reservoir. The material balance procedure requires considerable time, effort, and expense on the part of the engineers involved. The performance estimate generally consists of the extrapolation of a production rate versus time or cumulative production plot. A nominal estimate is generally a judgmental estimate used when data essential for more reliable estimates are unavailable. In addition to these four types of estimating procedures, such methods as reservoir modeling to duplicate past history and predict future reservoir behavior are often undertaken. 
The volumetric method of calculating resources and reserves is used in a newly discovered reservoir, and/or where little is known about the reservoir's production capabilities, and when the reservoir is not yet declining in its production rate. The volumetric method can also be used on a field basis where there are numerous reservoirs in the field, and the reservoir data have been volumetrically weighted or averaged.

The material balance and reservoir modeling methods of estimating resources and reserves are preferred by petroleum reservoir engineers. However, both methods require extensive knowledge of well production and pressure histories, and these are rarely available outside of individual company files.

The performance method or decline curve analysis works best on individual reservoirs where production is declining and the reservoirs are not prorated. In other words, all wells completed in the reservoirs should be producing at full potential or maximum efficient rate and the production is declining. If all wells are not producing at unrestricted rates, then the method is used for individual wells that are producing at unrestricted rates and declining in production. One further condition to the use of this method is that the reservoir should not be under the influence of an active water drive.

The nominal method is largely a best guess based on a judgmental factor or, more appropriately, should be called a cursory estimate. If a field's recovery is known and nearby fields have similar characteristics, then the known recovery per well can be applied to these fields. Another type of nominal estimate uses production-to-reserve ratios.

\section{0i1 Recovery Estimating Procedures for Nigeria}

The estimates of crude $0 i 1$ recovery from the 169 known fields in Nigeria were made by a volumetric or nominal method. In some cases, volumetric calculations were made using published or estimated parameters in an attempt to verify the ultimate recovery reported in the literature for specific fields. Also, oil recovery for some fields that were not reported in the literature were calculated by the volumetric method when an acceptable amount of data were available. The volumetric calculations give the 00IP which, in turn, is multiplied by an estimated recovery factor to get ultimate recovery These calculations resulted in acceptable estimates of oil recovery for 62 fields. These fields contain the bulk of the oil recovery estimated for known fields in Nigeria. However, the recovery estimates for these 62 fields should be considered cursory estimates based on engineering judgment rather than precise engineering calculations because much of the data utilized was estimated from limited information.

For the remaining 107 fields, oil recovery was estimated by nominal methods. The first of these methods utilized analogous known fields. The known reservoir and fluid characteristics of the remaining fields were compared to those of the 62 fields mentioned above. The oil recovery per well in 34 matching fields was used as an analogue for estimating the oil recovery per well. This analogue for oil recovery per well was applied to the set of 34 fields to estimate the oil recovery per field. 
A second nominal method consisted of averaging the oil recovery per well from the known 62 fields and applying that oil recovery per well to wells in the remaining 73 fields.

\section{0i.l Reserves and Original 0 il in Place}

The procedures for estimating total oil recovery per well provided the necessary data for determining the remaining oil reserves and 00IP for each field. Remaining reserves were calculated by subtracting cumulative oil production from ultimate oil recovery under current operating practice. Remaining reserves were estimated for a total of 169 fields. This is more than are reported to be productive for the country because some field discoveries are shut-in, pending pipeline connection and further development. However, these unreported fields have existing reserves for known wells as long as the wells are not plugged and abandoned. The total remaining crude oil reserves for existing wells in Nigeria as of January 1, 1976, is estimated to be 11.3 billion barrels under the current operating practices.

Original oil in place is calculated to be 44.2 billion barrels by dividing ultimate oil recovery by a recovery factor for those fields where a volumetric estimate was not made. A recovery factor is estimated by EIA engineers on an individual field basis and averages 34.9 percent.

\section{Potential 0il Reserves From Secondary Recovery}

Secondary recovery does not appear to be a major contributing factor to the potential recovery in this country. Most of the published data indicate that the fields are under very active water drives (encroaching edge or bottom water), and therefore are not likely candidates for secondary recovery. A cursory estimate of conventional secondary recovery potential indicates about 1 billion barrels of eventual secondary oil production. There ive, the total proved and potential oil reserves from known fields are estimated to be 12.3 billion barrels.

The secondary recovery potential-estimating procedure consisted of identiiying those fields that were under gas expansion drive or when the drive :sechanism was not known. Utilizing a rule of thumb, that the volume of secindary oil recovery will equal the volume of primary oil recovery in successful projects results in an estimated 1.97 billion barrels of potential secondary recovery oil. However, as stated, the drive mechanism in some of the fields was not known and not all projects would necessarily be successful. Therefore, the subjective estimate was reduced by approximately one-half, resulting in a total of 1 billion barrels for potential secondary oil recovery. 
The reader may question the logic of the foregoing when consideration is given to the reinjection of solution gas, which is currently being flared, back into the large, associated gas caps. However, reinjection of gas into very active water drive fields is more of a gas conservation effort than it is a secondary recovery effort unless one is trying to hold the oil-water contact constant. This practice can also be a highiy efficient oil recovery method (providing two sweeps through the reservoir are made, one being displacement with gas and the other being displacement with water) but could result in a loss of a large portion of the gas in the blowdown stage. Therefore, the reinjection of solution gas is not considered in the estimating procedure even though the practice could result in an increase in oil recovery. If reinjection were considered, detailed digital or numeric modeling would be required to make estima tes of the best method of recovery and quantify the potential secondary oil, and the data needed are not available. Current plans in Nigeria are for the liquifaction of the gas being flared and its sale as LNG.

\section{Data Sources and Reserves Comparison}

The data in this study came from various sources such as the AAPG Bulletins, International Petroleum Encyclopedia, World $0 i 1,0 i 1$ and Gas Journal, Journal of Petroleum Technology, Twentieth Century Petroleum Statistics, Petroconsultants Giant Field Files and others. These data are limited for Nigeria, and some are suspect. Discussion with certain staff of private concerns resulted in a further effort by them to obtain additional data needed.

There is very close agreement in published figures regarding Nigeria's proved reserves. It is believed, however, that this may be largely a matter of snurces quoting from each other rather than independent estimates. Some of the higher estimates (in the range of 18-20 billion barrels as of January 1,1978 ) are believed to be estimates of ultimate recovery. If one subtracts Nigeria's cumulative production of 6.11 billion barrels to January 1, 1978, from the lower limit of these estimates, it would leave 12.0 billion barrels of remaining reserves which is in close agreement to the range of 12.0 to 13.0 billion barrels reported by other sources. Also, EIA's estimated 12.3 billion barrels agrees with these estimates.

Current industry estimates cited in the literature with respect to natural gas reserves are in the range of $43(2)$ to 52 (3) trililion cubic feet. At the onset of this study, it was anticipated that the reserves of natural gas could also be estimated by EIA, as well as the oil reserves. However, thie data necessary for such estimates were more limited than those for oil. Therefore, natural gas reserves were not estimated by EIA.

(2) International Petroleum Encyclopedia, The Petroleum Publishing Co., 1978 , p. 270.

(3) Twentieth Century Petroleum Statistics, DeGolyer and MacNaughton, 1978 , p. 16. 
Nevertheless, it is believed that large quantities of natural gas liquids and liquified natural gas as well as condensate could be produced in the country for export or internal consumption when and if natural gas liquifaction plants are installed.

\section{Range of Possible Production Capability Profiles}

The method used to develop possible supply patterns of Nigerian crude oil is based on the works of Dr. M. King Hubbert (4), and relies heavily on logistic curves, cumulative proved discovery data, and cumulative production data. The two data series used in this analysis were purchased from Petroconsultants SA, Geneva, Switzerland. (Note: Mention of the data source does not in any way imply endorsement of that firm by the EIA nor does it guarantee the accuracy of said data.) The data are also protected by contract with the U.S. Government and by copyright laws for the company. From annual production $\left(\Delta Q_{p}\right)$, the cumulative production $\left(Q_{p}\right)$, can be
calculated and used in the following equation:

$$
Q_{p}=Q_{D}-Q_{P}
$$

where $Q_{D}=$ cumilative discoveries, and

$$
Q_{r}=\text { remaining reserves at the end of any given year. }
$$

Therefore : transposing:

$$
Q_{D}-Q_{r}+Q_{p}
$$

That is, irie cumulative proved discovery of oil as of any given year is equal to the remaining proved reserves at the end of that year plus the cumulative production at the end of that year. Delta $Q_{D}\left(\Delta Q_{D}\right)$, is the amount of $c: 1$ discovered in a given year (rate of change of cumulative discovery) and $\Delta Q_{p}$ (rate of change of cumulative production), is the amount of $0 i l$ production in any given year when $\Delta Q_{D}$ and $\Delta Q_{p}$ are calculatedon an annual basis. Delta $Q_{r}\left(\Delta Q_{r}\right)$, is the rate of change in the remaining reserves per year. When ${ }^{r} Q_{p}$ réaches a maximum, $d Q_{r} / d t$ (the instantaneous rate of change in remaining reserves) is equal to zero. At this time, $d Q_{D} d d t$ (the instantaneous rate of change in proved discovery) is equal to $d Q_{p} / d t$ (the instantaneous rate of change in cumulative production). Thus, the derivatives can be written as:

when $d Q_{p^{\prime}} / d t=0$, then $d Q_{p} / d t=d Q_{D} / d t$.

(4) Hubbert, M. K. U.S. Energy Resources, A Review as of 1972, Serial No. 93-40 (92-75), Part I, 1974, 267 pp. U.S. Government Printing Office, Washington, D.C. 
Hubbert was very careful in his report prepared for the Committee on Interior and Insular Affairs (4), to specifically state that "the curve of annual production for any given fossil fuel, whether for a local geographical region or for the whole world, must have the following characteristics: Such a curve must begin at zero. It must then rise until it reaches one or more maxima. Then, inevitably, as the quantity of the resource in the specified region either approaches exhaustion or becomes prohibitively difficult to discover and extract from the earth, the curve of annual production must eventually decline to zero." He also indicates that for larger regions, such as the United States, that the local fluctuations would tend to cancel each. other and the combined production statistics are far more likely to. give a single cycle having but one principal maximum. The functional form he selected to describe the cumulative discovery curve for the United States is the logistic equation. Using this functional form, Hubbert writes:

$$
Q_{D}=Q_{\text {max }}\left(1+\alpha e^{-\beta\left(t-t_{0}\right)}\right),
$$

where $Q_{D}=$ cumulative proved discoveries,

$$
\begin{aligned}
& Q_{\text {max }}=\text { ultimate recovery, } \\
& \alpha=a \text { constant, } \\
& \beta=a \text { constant, } \\
&(t\left.-t_{0}\right) \text { denotes the time after some reference period } t_{0} \text {, and } \\
& e \text { denotes the base of the Naperian logarithms. }
\end{aligned}
$$

The choice of this function for $Q_{0}$ implies that the growth and decay of the discovery rate is symmetrical about a given point in time.

Hubbert assumes that the cumulative production curve, $Q_{p}$, roughly takes the same path as the cumulative discovery curve, $Q_{D}$, lagged by an approximate time interval, $\Delta t$.

Hubbert's method of estimating the parameters used in the logistic equation was never published by him using formal statistical methods.

(4) Work cited on pg. 18. 
However, Noel D. Uri, of EIA, in a recent publication, (5), has suggested a procedure for estimating these parameters. The same type of procedure as used in Uri's publication was employed to estimate the parameters for the logistic curves developed and presented herein. The procedure used by Uri is known as the full information maximum likelihood (FIML) method of TSP version 3.1 (6), and is obtainable on the EIA computer. However, the production capability schedule herein was determined by an important modification in this method in that $Q_{\max }$ in the logistic equation was estimated independently by EIA from an estimate of the undiscovered 00IP prepared under the International Resource Appraisal Program of the USGS.

Viewing $Q_{\max }$ (ultimate recovery) as an externally determined parameter has several effects as follows: The parameters calculated to fit the logistic curves to result in the externally estimated $Q_{\max }$ are different than what they would be by letting $Q_{\max }$ be a variable. This results in the logistic curves being forced upward or downward (whichever the case may be; in this case, upward), to reach the constant $Q_{\max }$. This is essentially what Hubbert did when he set $Q_{\max }$ at $170 \times 10^{9}$ barrels for the United States (4). The cumulative production curve is also forced in the same direction as the cumulative discovery curve resulting in higher or lower production scheduling. Delta $t$, the time lag between cumulative production and cumulative discoveries is either shortened or lengthened, depending upon how much larger or smaller $Q_{\max }$ is set above or below the value of $Q_{\max }$ one would normalily calculate, keeping $Q_{\max }$ as a parameter to be determined.

As previously stated, considering the extreme range of values, the mean ultimate oil recovery was selected for illustrative purposes to estimate the maximum production capability profile and illustrate the techniques used. In these techniques, the parameters $\alpha$ and $\beta$ described earlier were calculated with $Q_{\max }$ set as a constant $27.1 \times 109$ barrels. Thus, the cumulative discovery curve, $Q_{D}$, and cumulative production curve, $Q_{p}$, were calculated using the logistic equation and also with a modified version of the logistic equation.

(4) Work cited on pg. 18.

(5) Uri, Noel D. A Re-Examination of Undiscovered 0 il Resources in the United States. December, 1978, 16 pp., U.S. Department of Energy, Energy Information Administration, Washington, D.C.

(6) Hall, Bronwyn H. TSP, Time Series Processor (Version 3.1), Energy Laboratory, No. MIT-EL 76-002 P, Report submitted to the Federal Energy Administration under FEA Contract No. CO-03-60411-00, January, 1976. 
A. Fortran program was written that computes the path of the logistic curves. With that program the delta cumulative production, $\Delta Q_{p}$, (defined herein as the annual capability to produce), was calculated annually to a point in the future where $Q_{m a x}$ would be obtained. This represents the capability to produce annualty out to a 100 percent depletion level. That is, the capability to produce at annual rates equivalent to $\Delta Q_{p i}$ through $\Delta Q_{p n}$ to 100 percent depletion providing there were no political restraints and there is a market for the oil.

\section{Production Capability Schedule - Standard Logistic Equation}

When using the standard logistic function to estimate cumulative discoveries for the U.S., it is assumed that the cumulative discovery rate and the cumulative production rate will decline at some breakover point in time. Also, the derivative of the logistic curves are symmetrical about that point in time.

Figure 6 is derived from the logistic equation predicting discovery rates and cumulative production rates. The results shown suggest that Nigeria might have the capability to produce at an unrestricted rate of about 3.8 million barrels per calendar day in its peak year which occurs in 1982, and also suggests that the annual decline rate after peak capability is attained would exceed 20 percent if the oilfields were produced at this unrestricted rate. EIA engineers do not consider this case to be reasonable because an exploration and development program will most likely continue for a long time into the future, thereby reducing the rate of production decline.

IL worid seem more reasonable to shift the calculated curve shown in figure 6.50 it intercepts the last known data point in 1977. This can be done sinsply sy setting the quantity, $-\beta\left(t-t_{0}\right)$ in the equation equal to $-\beta\left[(t)-\left(t_{0}+3\right)\right]$. However, all this accomplishes is to shift the peak unrestricted daily rate of 3.8 million barrels to the year 1985 . While the peak production rate seems to be more reasonable for this point in time, the decline rate after this peak rate again does not seem feasible. Nigeria was producing about 6 percent of its proved reserves during 1977 and slightly more than 6 percent during the highest output year of 1974 . Assuming that Nigeria could produce 10 percent of their reserves results in an unrestricted productive capability of $3.45 \mathrm{MM}$ bopd which is less than the calculated peak production rate using the standard logistic function. It is certain, however, that the country could have produced more than the average actual output of about 2.1 MM bopd during 1977 . Just how much more is conjectural and would have been limited because of surface facility restrictions. The Centrai Intelijigence Agency reports. a sustainable producing capacity of $2.4 \mathrm{MM}$ bopd which is about 90 to 95 percent of installed equipment capacity as of June 1979. 


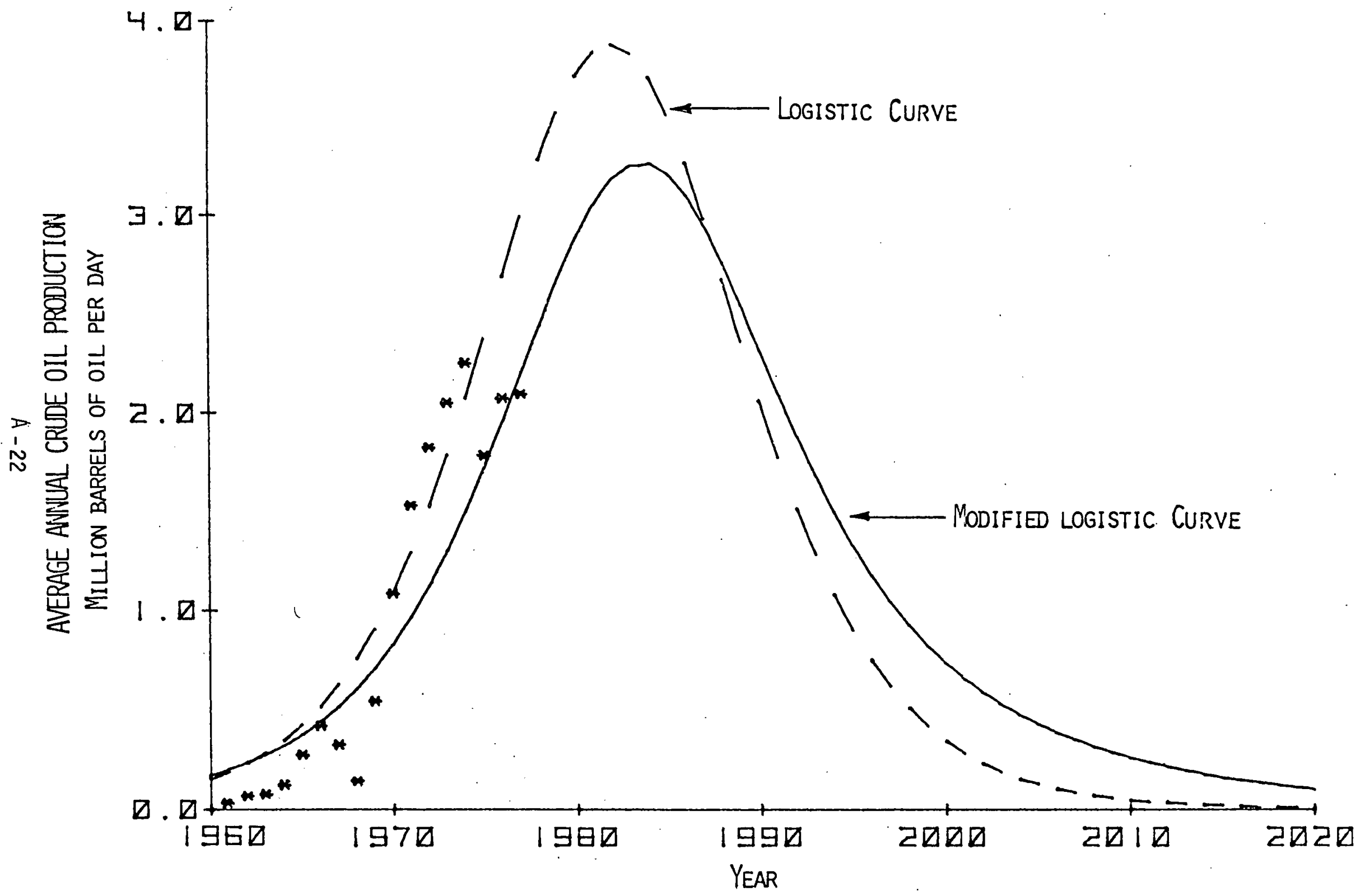

FIGURE 6. - Maximum production capability profiles using mean ultimate recovery $\left(27.1 \times 10^{9}\right.$ bbl) for. Nigeria. 
Specific government action may have slowed the growth of proved reserves in the latter half of the 1970's. Because of a lack of market, the Nigerian government curtailed production and this action may have slowed the drilling effort. However, by early 1979, the government. permitted production slightly above 2.4 MM bopd which is Nigeria's alltime high. Whether or not this action will result in higher exploratory activity by industry is not certain.

It is believed that most of the undiscovered $0 i 1$ resources of the country will probabiy be found in the near offshore province of the Niger Delta. These resources probably will not be developed as fast as those in the onshore prolific belt. This is due to definite long-term time lags involved from discovery to production. Platforms have to be ordered, built and placed on location before developmental drilling can begin. Pipelines have to be built also before production commences. Furthermore, the undiscovered commercial oilfields offshore may not be as numerous as those discovered onshore. As one progresses south of the prolific belt to the coast, the geologic structures seem to become more "gas prone." However, there may be as many structures offshore as onshore and the second largest oilfield in Nigeria (Nembe Creek) is south of the prolific belt.

Because the method employed by Hubbert for the United States assumes that the production and reserves are discovered at the same rate in the future as that of the past results in what is believed to be too rapid a decline in production for Nigeria, some adjustments must be made. This is because it is believed that while the country's Niger Delta is in the mature stage of exploration and development and the discovery rate will slow down as it has in other mature areas, it nevertheless will be enough to reduce the rate of production decline. Therefore, EIA engineers believe based on their knowledge of the geology of the offshore area and the foregoing discussion, that the rate of discovery offshore will be much slower than it was onshore in the past but it will be enough to reduce the rate of production decline. Hence, a method was devised to decelerate the logistic curves after peak production capability is attained.

Production Capability Schedule - Modified Logistic Equation

As previously noted, M. King Hubbert's method of prediction for the United. States is based on a symmetrical mathematical function which is the derivative of the s-curve (logistic curve) thought to be representative of the cumulative discovery function in a closed system. However, one must consider the fact that Hubbert's representation was proposed for the U.S. industry experience which was developed over a period of approximately 100 years and covers many provinces, whereas Nigeria is only one province. Also, one must consider when applying such an analytical approach to other producing nations, the time frame in which these nations were developed. Technology and the state of the art of optimum exploration and development were being formulated during U.S. history. 
Technology, for all practical purposes, had been developed and existed as a reality as far as nations with recent oil development are concerned. Therefore, it does not seem unreasonable that the method could describe the United States very well but would fall short in description of other nations that have been developed in recent years. This is especially relevant when one considers the speed with which these countries are developed and the fact that the best structures are identified using modern technology and tested in a very short time after exploration begins. The question, therefore, is "are there better ways to mathematically describe the s-curve discovery and production functions for younger developing nations?"

It is believed that the time rate of change of Nigerian cumulative discovery and of cumulative production are not symmetrical functions, i.e., reserves found in any year will be discovered very rapidly at first and then begin to diminish on a per-well-or-footage basis, as well as slow down with time. In Nigeria, the net effect of this assumption is that annual production will increase rapidly during the first decade plus, rise to a peak, and then decline with time more slowly than it rose.

It is assumed that there will be sufficient exploration success arid development activity to maintain an oil production decline rate that gradually approximates 10 percent per year. Of course, the exponential decline rate can be varied, but setting it at about 10 percent seems reasonable. Therefore, for this analysis, the EIA has made the following assumptions:

1. The annual discovery function is not symmetrical with time;

2. The largest decline rate that will be experienced is fixed after peak production capability is attained and equal to $B_{2}$; and

3. $Q_{\max }$ is an externally determined constant.

The modified form of the logistic function chosen to incorporate these assumptions is:

$$
Q_{D}=\frac{\alpha_{3}}{1+\alpha_{1} e^{-\beta_{1}\left(t-t_{0}\right)}}+\frac{\left(Q_{\max }-\alpha_{3}\right)}{1+\alpha_{2} e^{-\beta_{2}\left(t-t_{0}\right)}}
$$

where $Q_{\max }=$ ultimate recovery, 


$$
\begin{aligned}
& \alpha_{1}=\text { a constant, } \\
& \alpha_{2}=\text { a constant, } \\
& \alpha_{3}=\text { a constant, } \\
& \beta_{1}=\text { a constant, } \\
& \beta_{2}=\text { a constant (20 percent), } \\
& \left(t-t_{0}\right) \text { denotes the time after some reference period, } \\
& t_{0}, \text { and e denotes the base of the Naperian logarithms. }
\end{aligned}
$$

This function is a sum of two logistic functions. The derivative of the first function increases rapidily, peaks sharply, and declines rapidiy. The second function increases more slowly, peaks later, begins declining more gently, and eventually declines at a rate of 10 percent per year. The derivative of the sum of the two curves increases rapidly, peaks at a lower rate than the rate obtained from the derivative of the standard logistic function and declines exponentially at a rate approximating 10 percent.

Delta $t(\Delta t)$, is the time between the last year's cumulative production and its corresponding cumulative discovery point on the discovery curve. The annual production capability curve, $d Q_{p} / d t$, for projection purposes is an exact replica of the cumulative discovery rate curve, $d Q_{D} / d t$, but it lags by $\Delta t$. It is understood that the production capability curve will not be identical in shape to the cumulative discovery rate curve but it should roughly approximate it, nor would it be expected that $\Delta t$ would remain constant in the future. The results obtained using the foregoing function are shown in figure 6 and labeled the modified logistic curve.

Figure 6 suggests that the maximum rate of production that could be obtained is 3.3 MM bopd, which would occur in the year 1984 if all production constraints are removed. However, it is pointed out that there are current equipment constraints as well as other infrastructure constraints on the production rates in Nigeria. It is speculative as to what level the Nigerian government will allow production to climb as is the rate at which industry can increase production. 


\section{Alternate Production Schedules}

The purpose of this section is to ascertain what Nigeria's long and short term supply capability is, i.e., how long Nigeria can supply oil at a given level. In order to make this determination, certain assumptions are necessary. Possible annual production levels can be assumed at any point up to an approximate peak level of $3.3 \mathrm{MM}$ bopd from the modified logistic curve shown in figure 6 . The basic problem is to determine when, at a constant oil production rate, decline will begin. This depends upon cumulative production, the selected production rate in ensuing years, the decline rate that would occur when production decline starts, and ultimate recovery. The only value that is known with reasonable certainty is the cumulative production. The ultimate recovery is estimated by multiplying the recovery factor by the mean value of the undiscovered OOIP, as estimated by the U.S. Geological Survey, and adding that value to total estimated ultimate recovery as of January 1, 1978, for known fields. For example, the resultant value is. 27.1 billion barrels for the mean ultimate recovery. The decline rate of 10 percent is also estimated as previously discussed.

To determine when oil production decline will begin at any given production level is a simple mathematical exercise, considering the assumptions made as three of the four required variables are known or estimated. These are: (1) the cumulative oil production of $6.11 \times 10^{9}$ barrels as of January 1, 1978; (2) the annual oil production decline rate of 10 percent; and (3) the mean ultimate oil recovery of $27.1 \times 10^{9}$ barrels as of January 1, 1978. One need only assume a constant annual production level equal to or below the peak level of 3.3 MM bopd as shown in figure 6 , calculate the production during decline to nearzero production level, add the cumulative production to the production during decline, subtract this sum from ultimate recovery, and divide the remaining ultimate recovery by the assumed constant production to obtain the number of years the constant annual production might be maintained. This procedure assumes that exploration and development would continue at a reasonable rate. The results obtained using the method described above are illustrated in the summary in figure 2. Also, the results obtained using the five different ultimate recoveries are shown in table 1 in the summary. 
UNITED STATES DEPARTMENT OF THE INTERIOR

\section{APPENDIX B}

\section{Petroleum Geology of the Niger Delta \\ by}

O. W: Girard, Jr.

U.S. Geological Survey

Reston, Virginia 220.92 


\title{
PETROLEUM GEOLOGY OF THE NIGER DELTA
}

\author{
by \\ 0. W. Girard, Jr. \\ U. S. Geological Survey \\ Reston, Virginia 22092
}

\section{Introduction}

Cretaceous-age and younger sedimentary rocks make up about half the surface area of Nigeria. The remaining half is made up of igneous and metamorphic rocks, which are unprospective for oil and gas. The greatest thickness of sedimentary rocks is in the southern part of Nigeria in the Niger Delta. The area of the Niger Delta is approximately the same size as the area of the Mississippi River Delta; however the oil and gas productive area of the Miocene, Pliocene, and Pleistocene trends of the Mississippi River Delta is considerably larger than the productive trends of the Niger Delta. Three major hydrocarbon trends are found in southern Nigeria, and these are from oldest to youngest: (1) lower Turonian and Senonian to lower Maestrichtian sandstones; (2) Maestrichtian bituminous sands; and (3) Eocene to Pleistocene sands (Fig. 1). Initial oil and gas exploration was concentrated in the Cretaceous trend north of the present Niger Delta; however, all current production is from Tertiary deltaic sands on which this paper will focus.

\section{Evolution of the Niger Delta Basin}

Evolution of the Niger Delta sedimentary basin began in Early Cretaceous time (Aptian and Albian) when the Benue-Abakoliki Trough originated as an arm of the triple-junction rift-ridge system that initiated the separation of South America from Africa (Fig. 2). The Benue-Abakoliki Trough was flanked by the Anambra Platform on the northwest and the Ikpe Platform/Oban Massif on the east-southeast. The trough was filled by more than 10,000 feet of sediments of Albian to Coniacian Age (Weber and Daukoru, 1975). During the Santonian, the Benue-Abakoliki Trough was uplifted to form the Abakoliki High/Benue folded belt, and the Anambra Platform was downwarped to form the Anambra Basin (Murat, 1970). Existing from the Campanian to the Paleocene were the large Anambra Basin and two smaller basins--the ofikpo Syncline and the Ikang Trough. Within the Anambra Basin was the Onitsha High, possibly formed by block faulting and tilting (Weber and Daukoru, 1975)--a tectonic style common to rifted continental margins. The formation of protodeltas, which started in the Cretaceous, was terminated by a major marine transgression in the Paleocene. The formation of the present Niger Delta began with a major regression in middle Eocene time. The great thickness of sediments that produce oil and gas in the Niger Delta Basin was deposited between Eocene and Holocene time (Fig. 3) (Weber and Daukoru, 1975). 


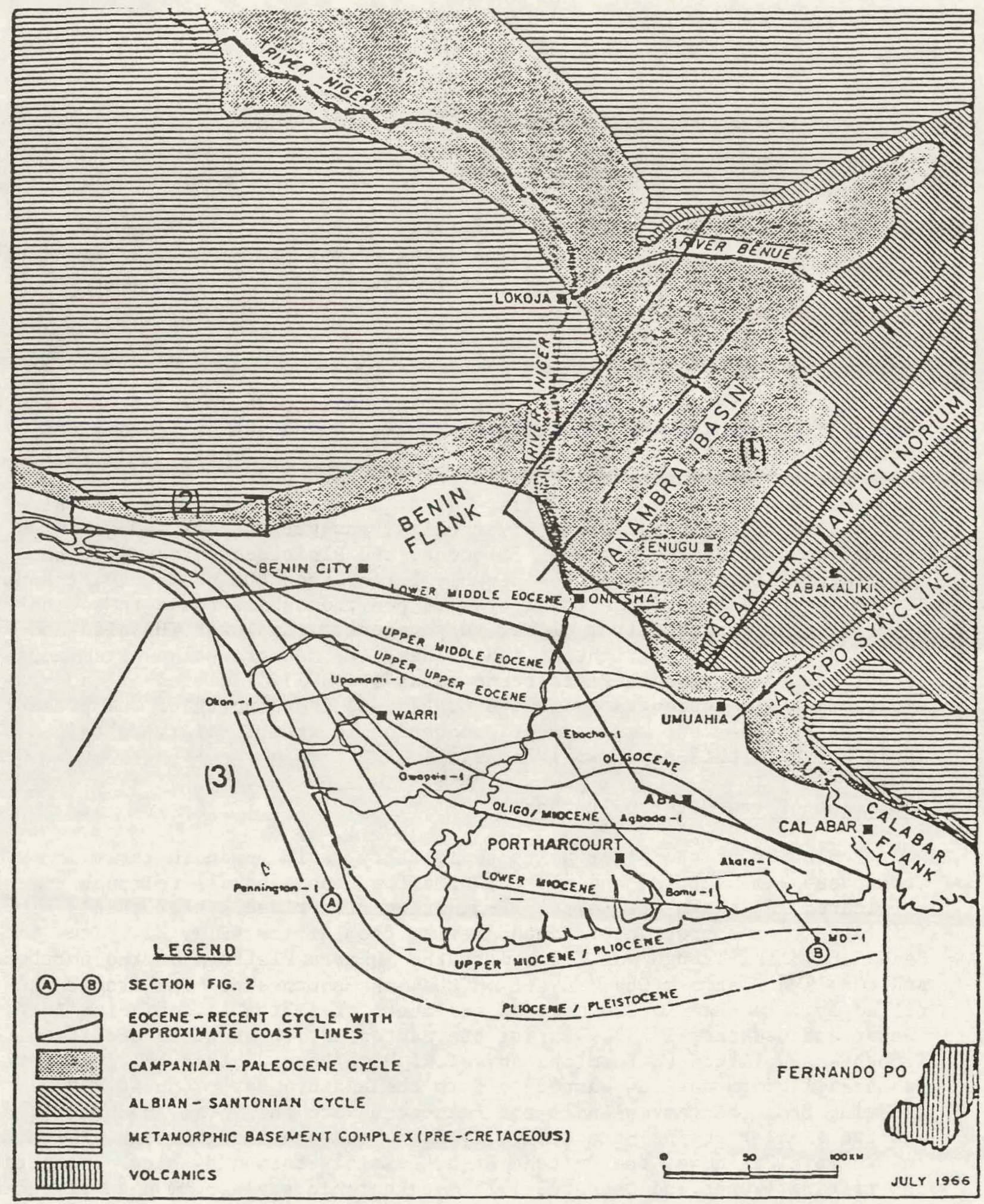

\section{(1) CRETACEOUS TREND}

\section{(2) CRETACEOUS BITUMINOUS-SAND TREND}

(3) TERTIARY TREND

Figure 1. General geclogical map and major producing, trends of the Niger Delta and environs (Modified from Avbovbo and Ogbe, 1978, and Fränkl and Cordry, 1967). 

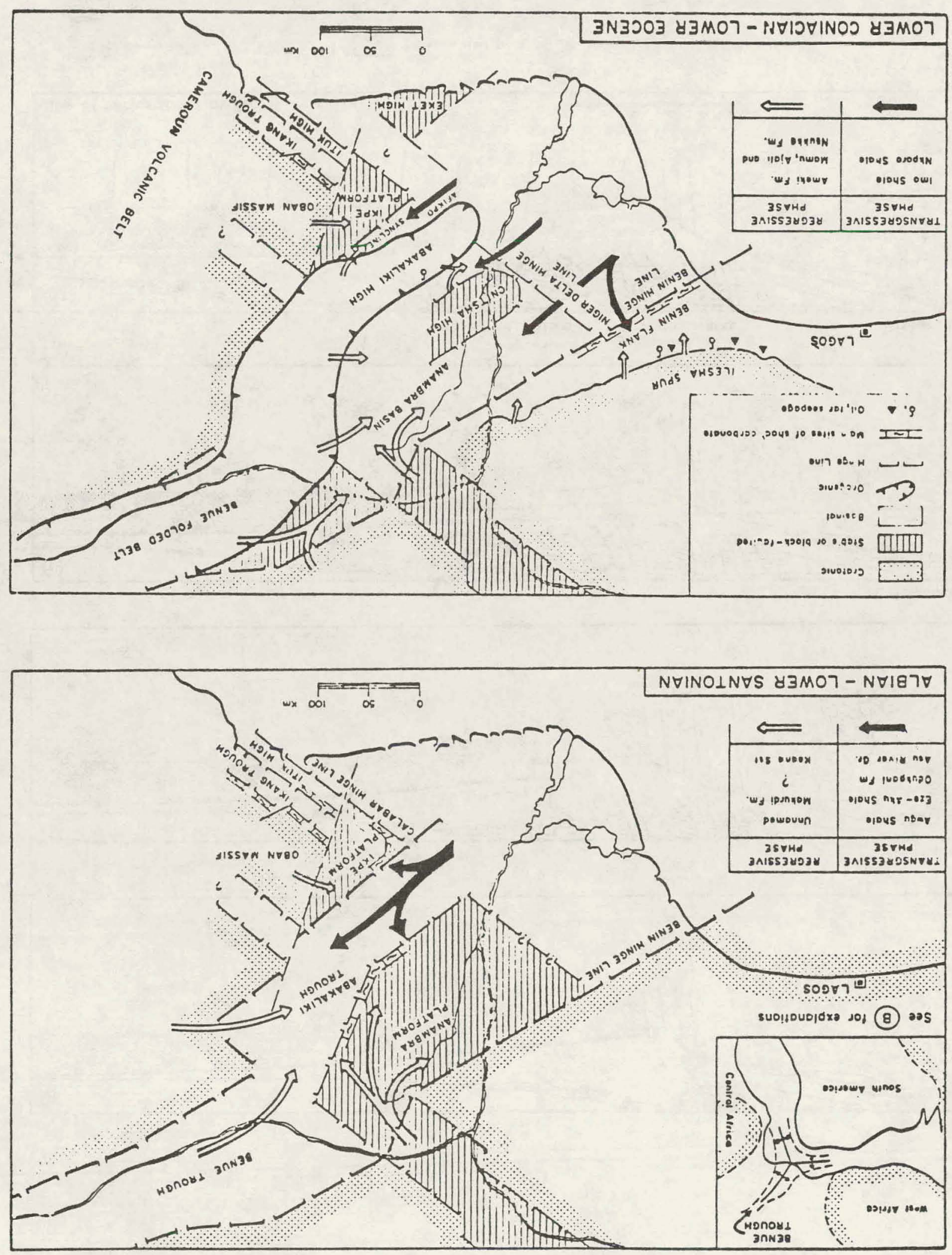


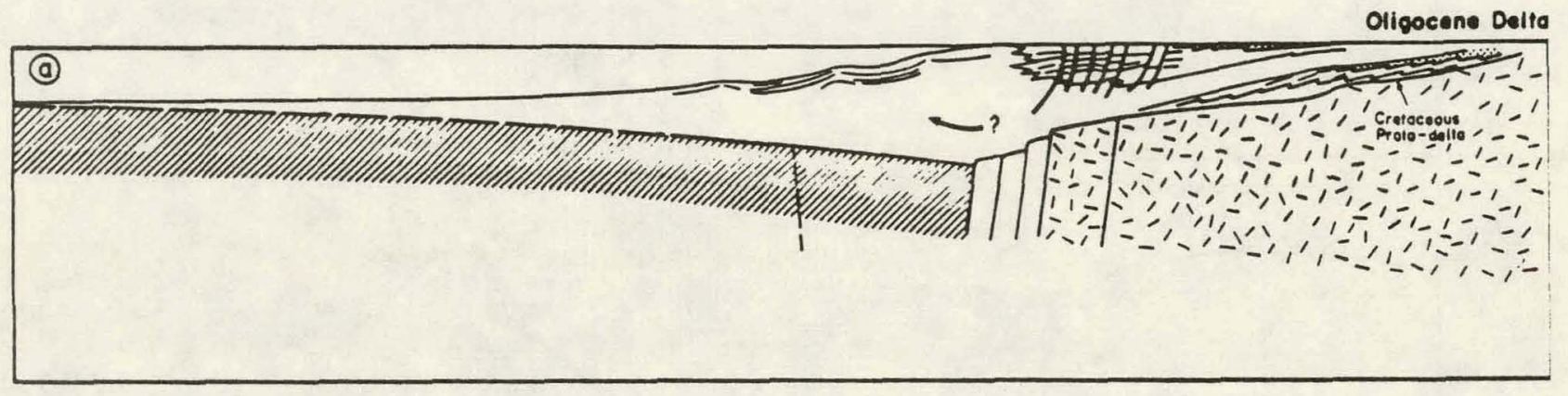

Mid-Miosene Delte
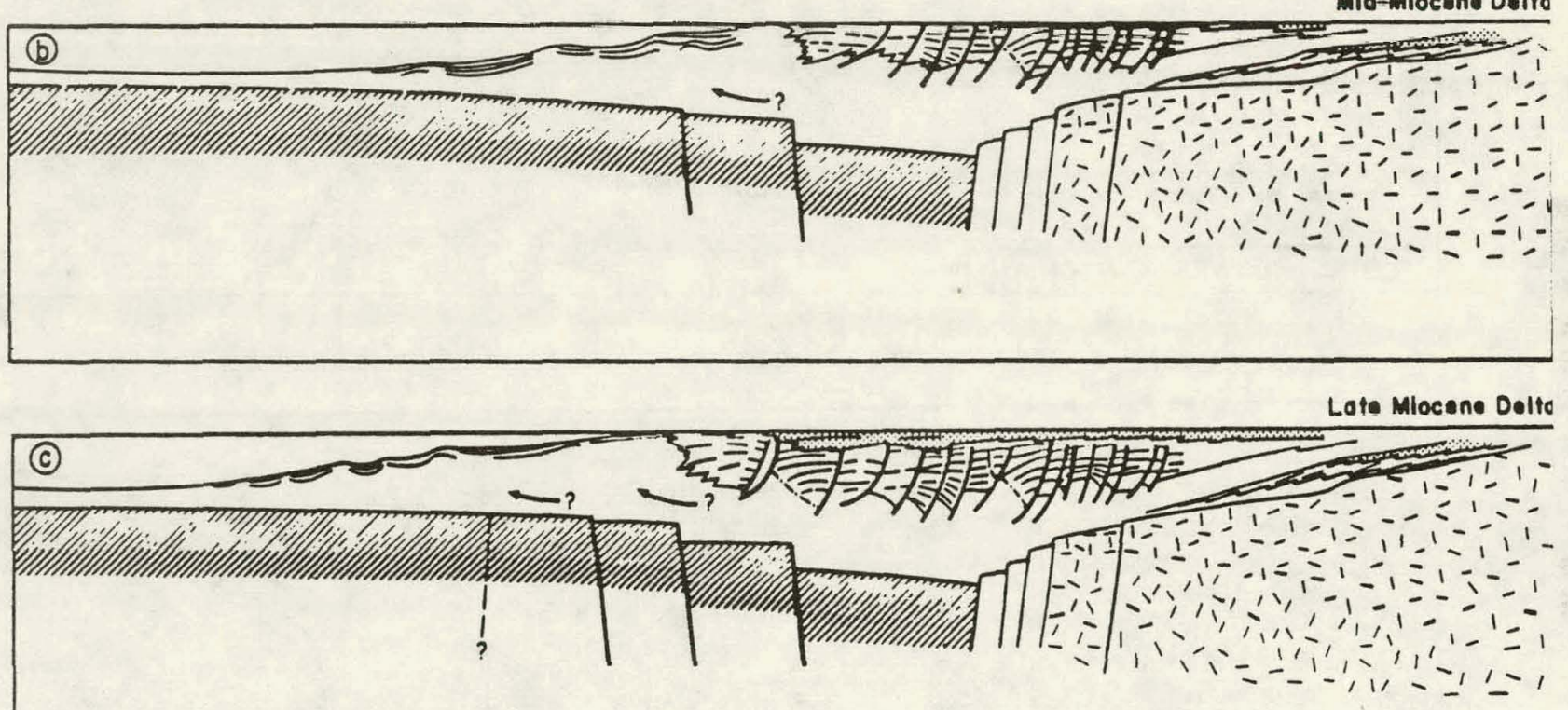

ssw

EA Cooot Line TAMEO KOKONI AERAKA

Present-doy

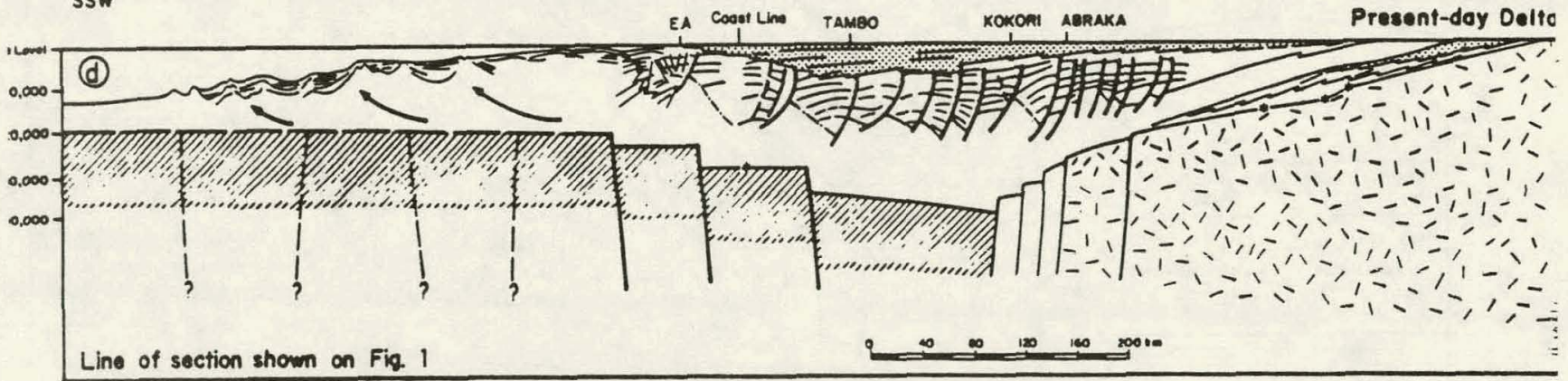

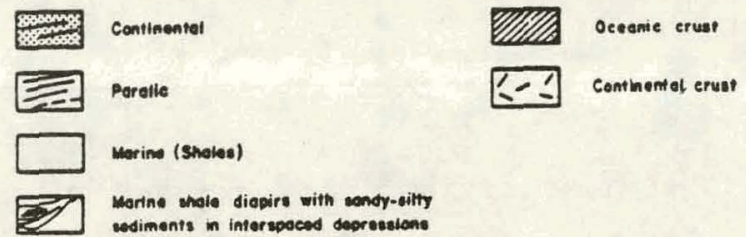

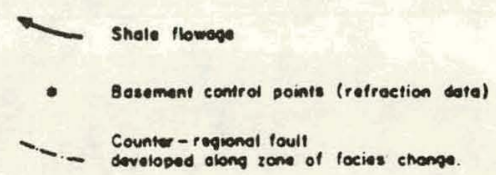

Figure 3. Tertiary evolution of Niger Delta (Evamy and others, 1978). 
$\underline{\text { Regional Stratigraphy and Reservoir Rocks }}$

The following discussion on stratigraphy, taken mainly from Short and Stäuble (1967) and Fränkel and Cordry (1967), is limited to the present (Eocene to Holocene) Niger Delta Basin. Beginning in the Tertiary, the sea transgressed the whole of southern Nigeria, terminating the development of Cretaceous protodeltas. As a result of this major transgression, the Imo Shale was deposited in an embayment with an axis roughly coinciding with the modern lower Niger River. The Imo Shale, deposited in neritic to bathyal environments, ranges in age from Paleocene to middle Eocene and is composed of shales with local interbeds of limestones, sandstones, and marls. Lateral arenaceous equivalents of the Imo are known in Eastern Nigeria.

After deposition of the transgressive Imo Shale, the bulk of Eocene to Holocene sediments that make up the thick wedge of sediments from which oil and gas are produced in the modern Niger Delta Basin (Fig. 4) were deposited during a major regression. Avbovbo and Ogbe (1978) estimated that approximately 28,000 feet of Tertiary sediments was deposited in the Niger Delta Basin. The thick wedge of Tertiary sediments has been divided into three diachronous (time transgressive) rock-stratigraphic formations: Akata Formation, Agbada Formation, and Benin Formation (Fig. 5).

The basal unit, the Akata Formation, is composed primarily of marine shales laid down in front of the advancing delta, and ranges in age from Eocene to Holocene. The benthonic foraminiferal assemblages indicate deposition of the prodelta shales on a shallow-marine shelf. The Akata Formation is characterized by uniform shale development with some sand and silt beds that were deposited in a deeper water environment (Weber and Daukoru, 1975). Little is known about the distribution and frequency of occurrence of these deep-water sands, because thick sections of shale, generally abnormally pressured, have to be drilled before the sands are found. These relatively unexplored sands could be important hydrocarbon reservoirs in the future. The Akata Formation underlies the whole Niger Delta and seems to be continuous but diachronous with the outcropping Imo Shale. The Akata Formation is penetrated in most of the onshore fields between 12,000 and 18,000 feet and in most of the offshore fields between 5,000 and 10,000 feet. For all practical purposes, the top of the Akata Formation (Fig. 6a) represents economic basement, with the possible exception of isolated deep-water sands mentioned above.

The Akata Formation is overlain by the Agbada Formation, which contains the primary exploratory objective/reservoir rocks of the Niger Delta. The Agbada Formation is more than 12,000 feet thick in the central part of the delta and ranges in age from Eocene far inland to Plio-Pleistocene offshore (Fig. 6b). The Agbada Formation, built from 


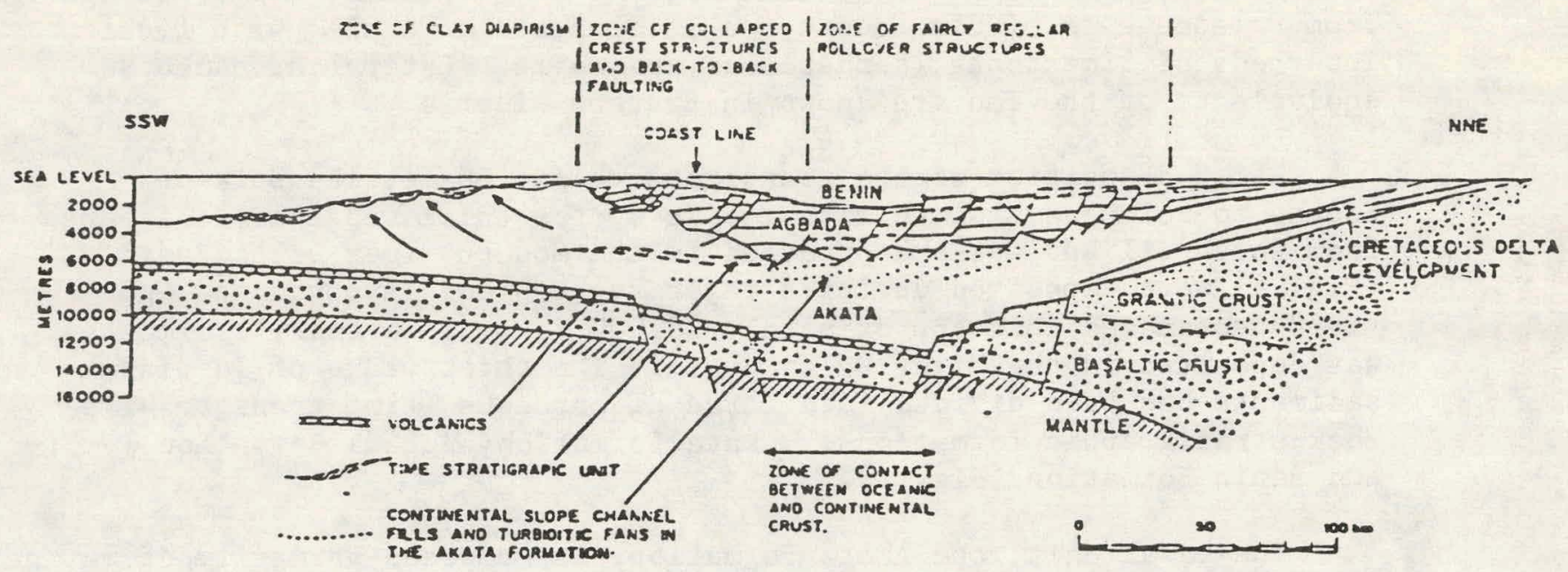

Figure 4. Schematic dip section of the Niger Delta (Fränkle and Cordry, 1967). 


\begin{tabular}{|c|c|c|}
\hline CAONOSTAATIO & ourenom & \\
\hline 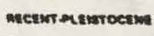 & \multirow{5}{*}{ 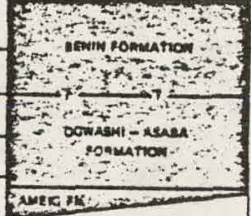 } & \\
\hline moceme & & DELTA SUBSURFACE \\
\hline mocene & & \\
\hline oucocent & & \\
\hline toceme & & \\
\hline DaLeocent & Mo Smace & \multirow{5}{*}{ TOUIVALENTE UNK NONW } \\
\hline Une atrominam & 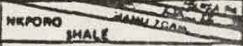 & \\
\hline 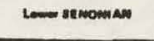 & \multirow[t]{2}{*}{ A WOU EMale } & \\
\hline TUMOAna: & & \\
\hline ALWuam & New niven onous & \\
\hline
\end{tabular}

DEPOSITIONAL ENVIRONMENTS

itser continental

Thaneutiomal

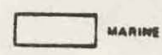

Figure 5. Type sketch of the Niger Basin stratigraphy and depositional environments (Aliu and Novelli, 1974). 


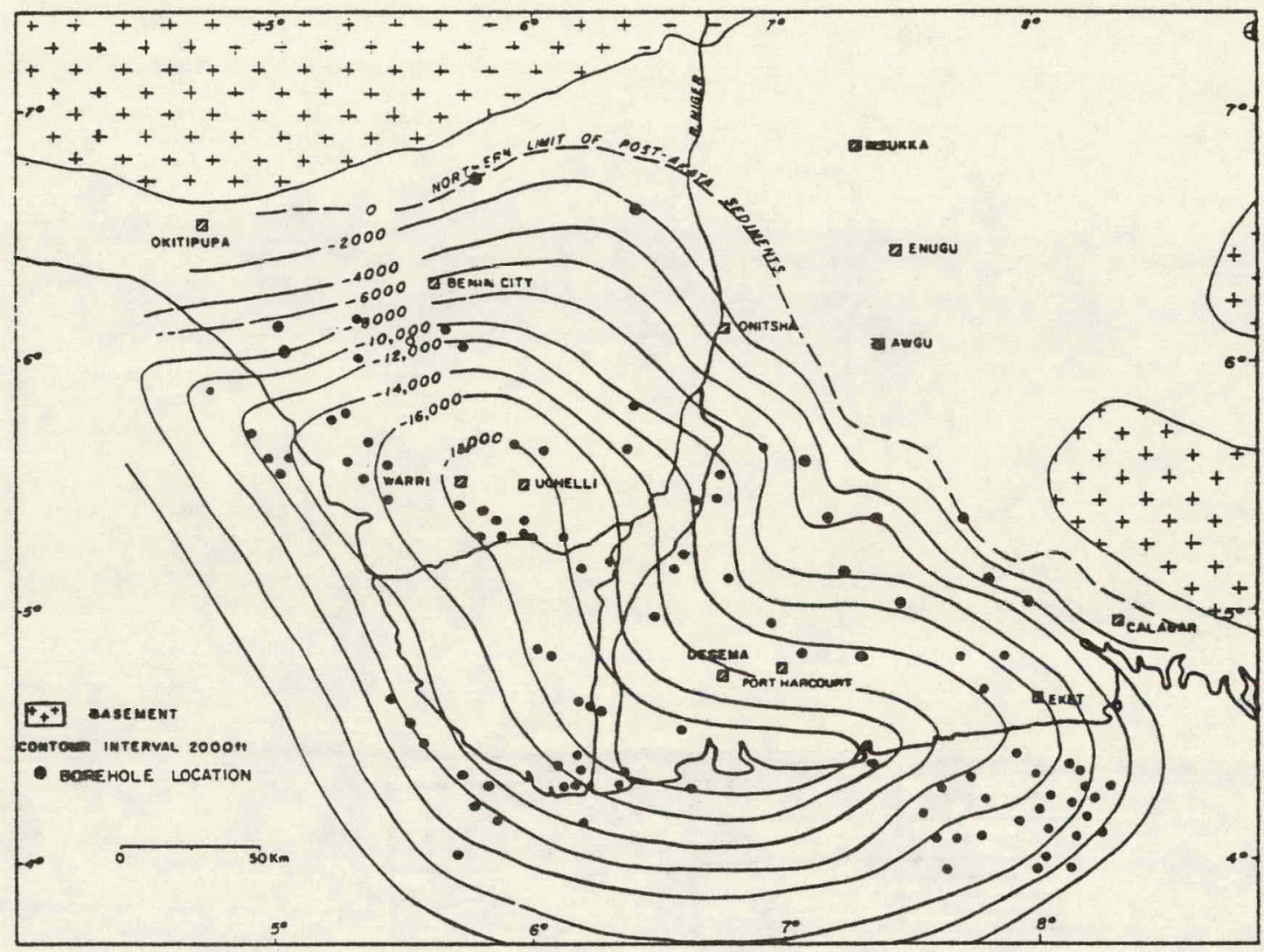

Figure 6a. Structural map of top of Akata Formation (Avbovbo, 1978).

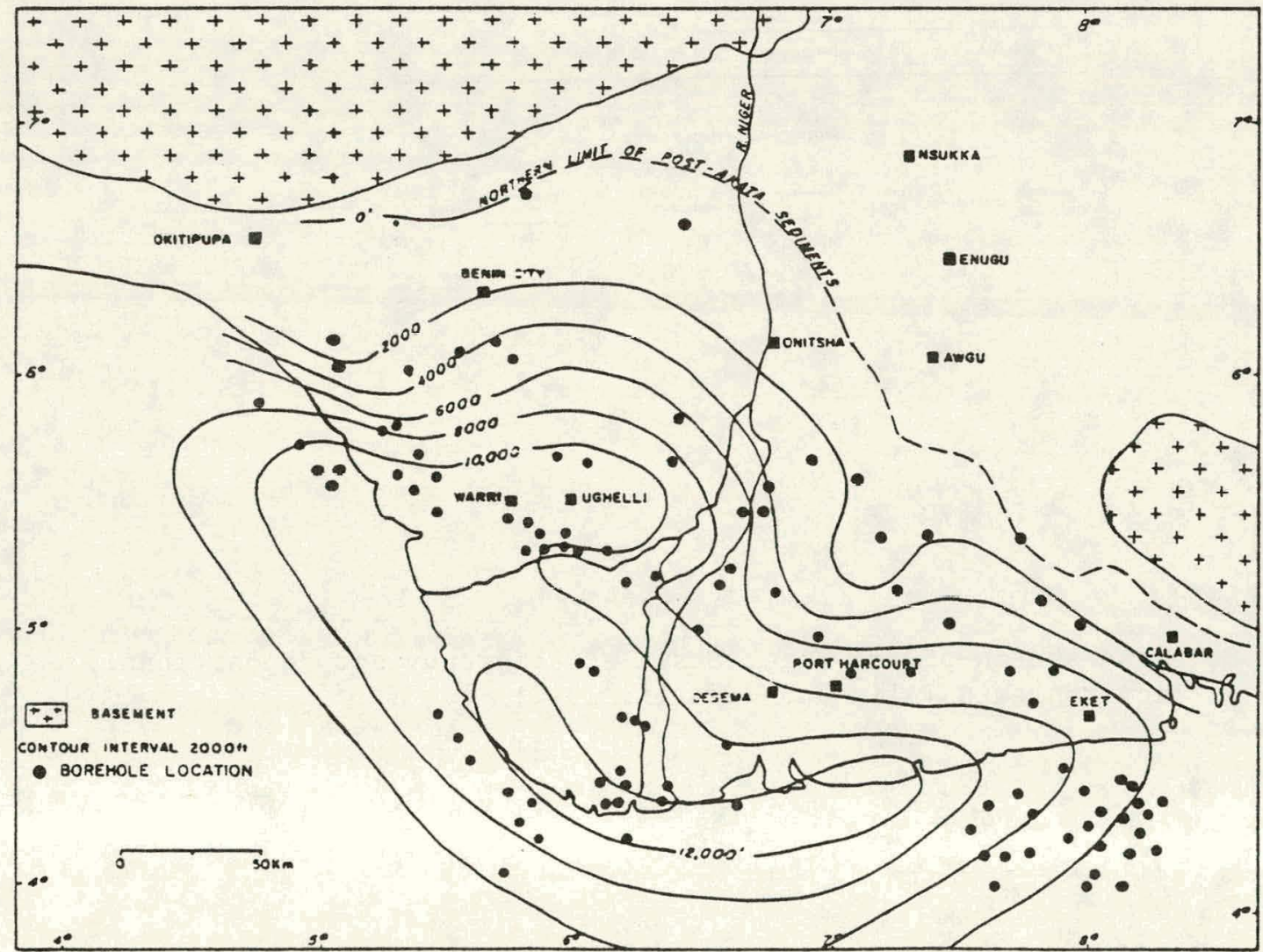

Figure 6b. Isopach map of Ågbada Formation (Avbovbo, 1978). 
numerous deltaic offlap cyclic sequences of marine and fluvial deposits, is present throughout the whole Niger Delta subsurface. Each depositional cycle ranges in thickness from 50 to 300 feet and, in ascending order, generally consists of a thin fossiliferous transgressive marine sand and an offlap sequence of marine shale and laminated fluviomarine sediments (Weber, 1971). This cyclic sequence of reservoir rock deposition explains the multireservoirs of most of the Nigerian oil and gas fields. In general, the upper part of the total Agbada section is intercalated sands (about 75 percent) and shales (about 25 percent). The lower part of the total section, which probably accounts for the bulk of the hydrocarbon reserves, is about 50 percent sand and 50 percent shale. The sandstones, which make up the reservoir rocks, are very coarse to very fine grained, slightly consolidated, feldspathic, fairly clean, and locally calcareous, glauconitic, and shelly. Sorting generally is poor. The shales are medium to dark gray, fairly hard and silty, and contain mainly kaolinite (75 percent) and small amounts of mixed layers of illite and montmorillonite (Avbovbo and Ogbe, 1978). These intercalated shales make up the vertical seals in the fields of the Niger Delta. In fact, the production takes place where it does because these transgressive shales act as vertical seals to the migration of hydrocarbons--the shalier than normal intervals are productive, and the sandier than normal intervals are nonproductive (Dailly, 1976).

Most of the reservolr rocks of the Nigerian fields are present in the Agbada Formation and are of excellent quality; porosities are between 28 and 32 percent and permeabilitites in the darcys (Habarta, 1970). The offshore Okan field has permeabilities as high as 5 darcys. The reservoir rock quality and geometry is strongly dependent on the depositional environment. For example, the pre-Miocene reservoir rocks were deposited as widespread continuous sands, point bars, and channel sands, whereas the Miocene to Holocene reservoir rocks were probably deposited as barrier bars less than 36 feet thick (Weber and Daukoru, 1975; Weber, 1971). The pre-Miocene delta was probably more lobate in shape, owing to the smaller influence of longshore currents, than the Miocene to Holocene delta, which was strongly influenced by the prevailing south-westerly winds and the regular pattern of longshore currents. This difference in current pattern could explain the difference in depositional environment. The multireservoirs in many of the fields are made up of superimposed reservoir rocks that were deposited in the same or different sedimentary environments. This adds to the complexity of the reservoir-rock system of most of the Nigerian fields.

The uppermost unit, the Benin Formation, is mainly freshwaterbearing massive continental sands and gravels deposited in an upper deltaic-plain environment with only local shale interbeddings (Fig. $7 \mathrm{a}$ ). The Benin Formation is as much as 6,000 ft thick; the area of maximum thickness is coincident with that of the Agbada Formation (Fig. 7b). 


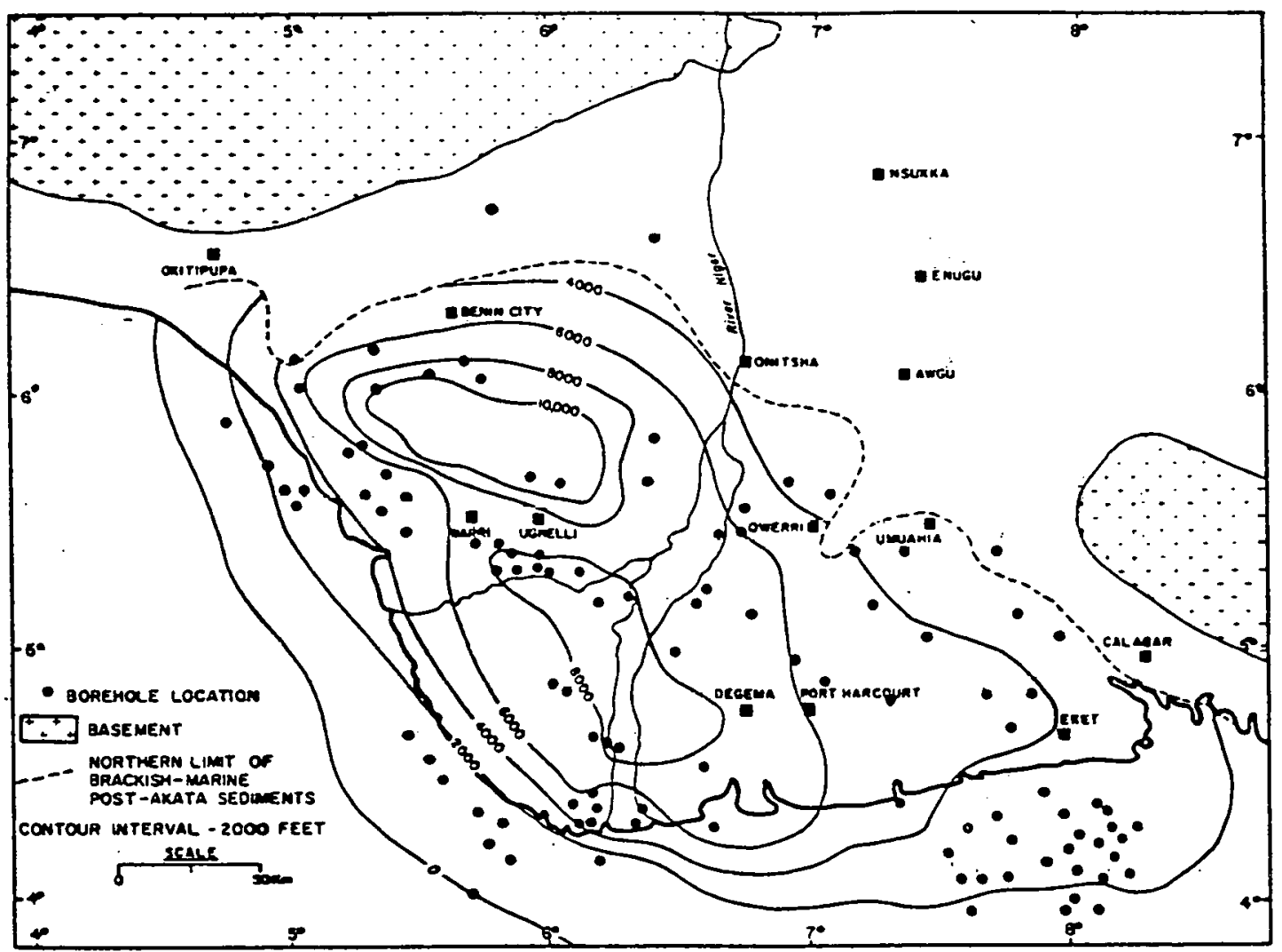

Figure 7a. Isopach map of freshwater-bearing Tertiary Formations (Avbovbo, 1978).

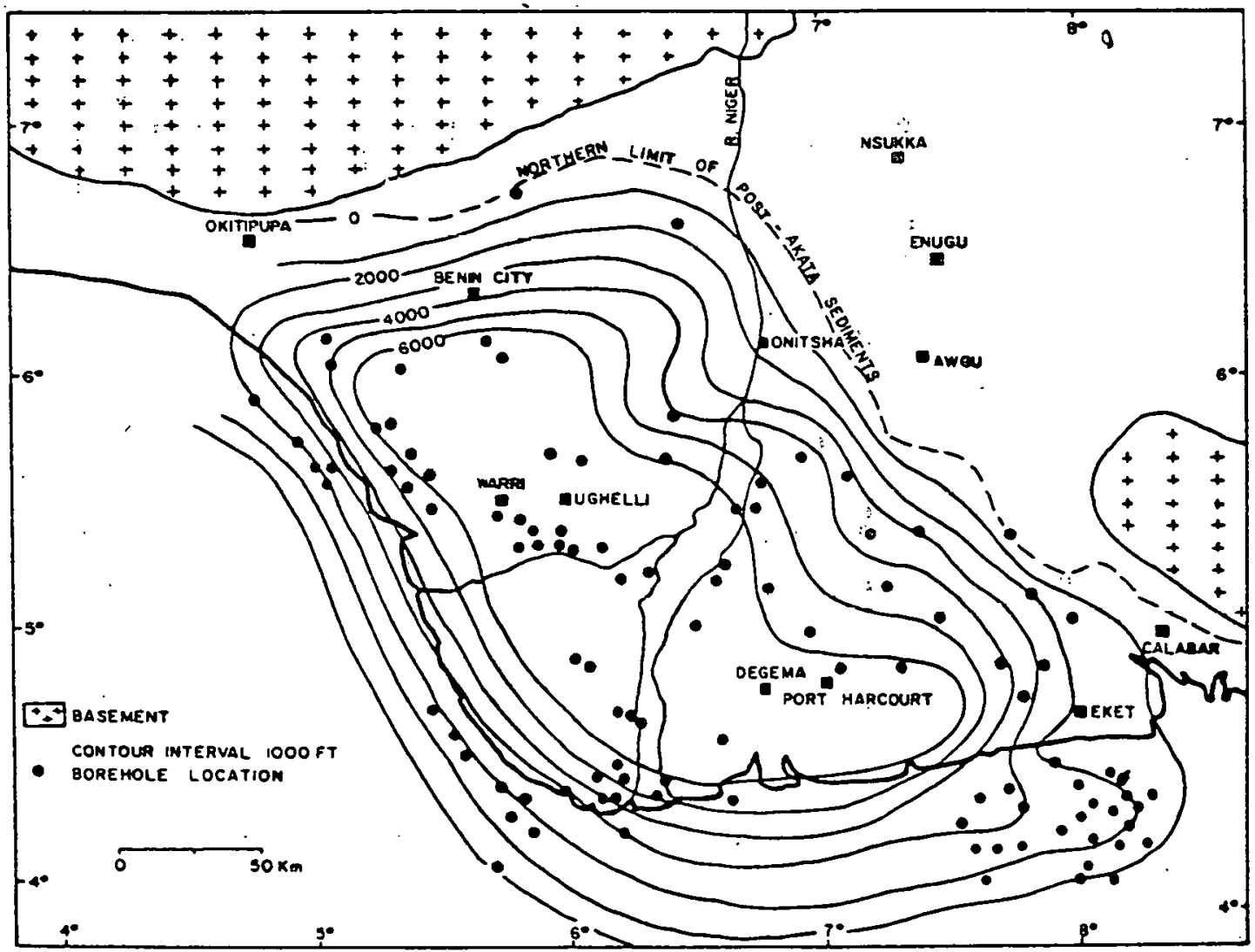

Figure 7b. Isopach map of Benin Formation (Avbovbo, 1978). 
The highest occurrence of marine foraminifera separates the Benin Formation from the underlying Agbada Formation (Short and Stauble, 1967, and Avbovbo and Ogbe, 1978). The sands and gravels of the Benin Formation may represent point-bar deposits, braided streams, channel fills, or natural levees, whereas the shales may be interpreted as backswamp deposits and oxbow fills. The sands and sandstones are coarse grained to very fine grained, very poorly sorted, subangular to well rounded, and do not show lateral continuity. The porosity of the sands is high, but the permeability is low. The few shales that are present are grayish brown, sandy to silty, and contain some plant remains and lignite. In the subsurface, the Benin Formation is 0ligocene in the north and Holocene near the coastline. Although the continental Benin Formation is generally freshwater bearing, highly porous, and has very few seals, a few fields, both onshore and offshore, produce from continental reservoirs. Figure 8 is a regional east-west stratigraphic cross section through the Niger Delta showing the Akata, Agbada and Benin Formations.

Regional Structure and Petroleum Traps

The Niger Delta has produced hydrocarbons from lower Turonian to, probably, Pleistocene-age rocks. However, virtually all the current Nigerian production comes from Tertiary-age rocks in the Niger Delta. The oil and gas production from the Niger Delta is typical of Tertiary deltaic production such as that from the U.S. Gulf Coast. Seventy-seven percent of the proven oil reserves has been discovered in a narrow arcuate trend that cuts across the depositional and structural trends of the delta from the offshore western flank of the Niger Delta to its offshore southwestern flank (Fig. 9) (Avbovbo and Ogbe, 1978). The fields north and south of this prolific arcuate productive trend account for only 8 percent and 15 percent of the reserves, respectively (Avbovbo and Ogbe, 1978). Like that of the Gulf Coast, the age of the production decreases in a seaward direction (Fig. 10). The fields located in the prolific arcuate trend produce from rocks of Miocene to Pliocene age.

These productive trends, like those of the Gulf Coast, are delineated by large regional growth faults, or a series of closely spaced en echelon growth faults (Fig. 11). The throw of these major regional growth faults is probably greater than 2,500 feet. The fault trends are parallel to the paleoshorelines and shelf edge. Because growth faults are syndepositional, their age decreases toward the present-day shoreline. The major regional growth faults that bound the productive trends updip "expand" the thickness of the downthrown time-equivalent section that produces within that trend.

Most of the traps in the Niger Delta are anticlines produced by differential compaction and rollover of strata on the downthrown block of regional growth faults. The fault generally does not provide the updip lateral seal but only the mechanism for trapping. Gentle undulations of the regional structural dip along the axis of the downthrown 


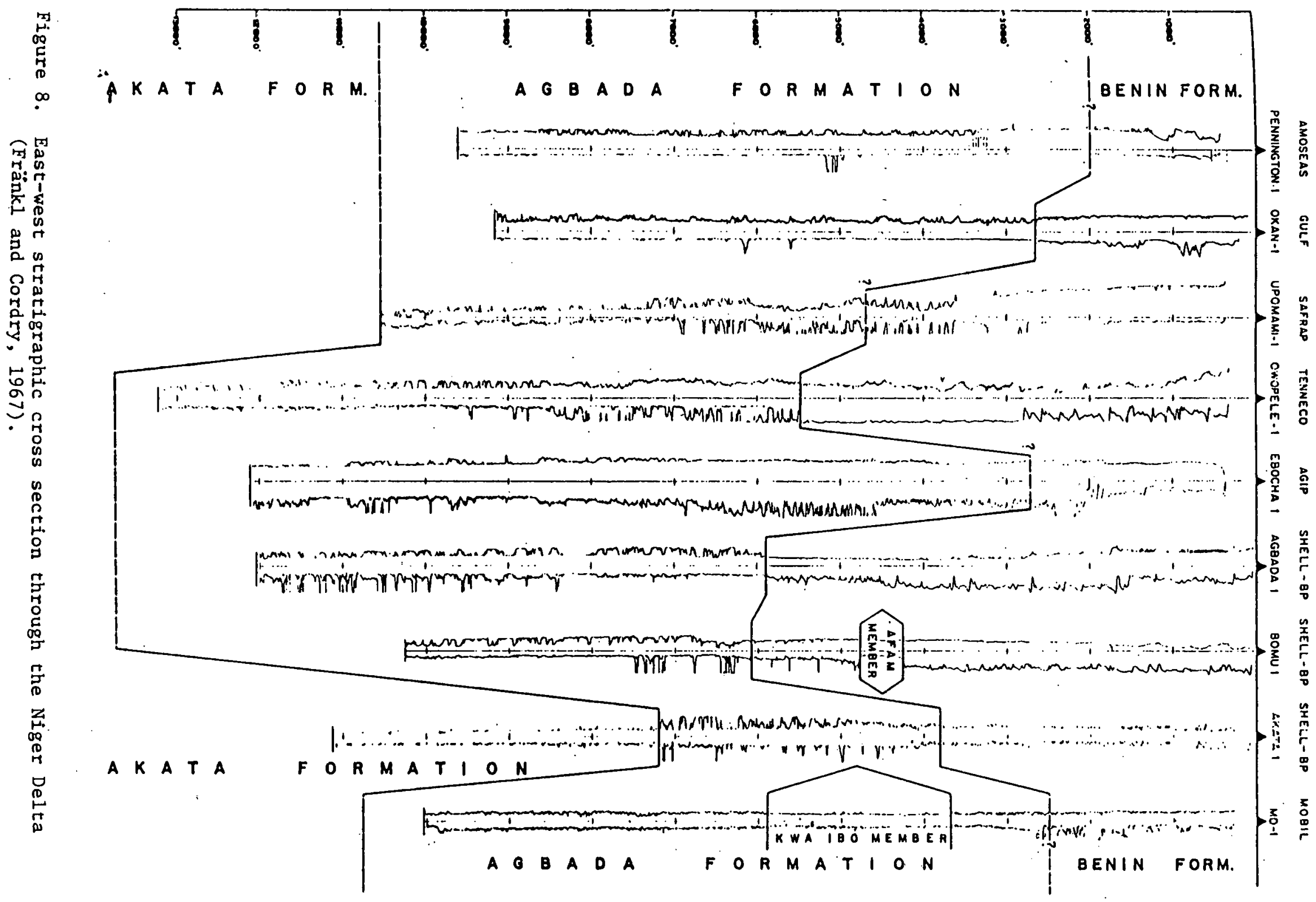




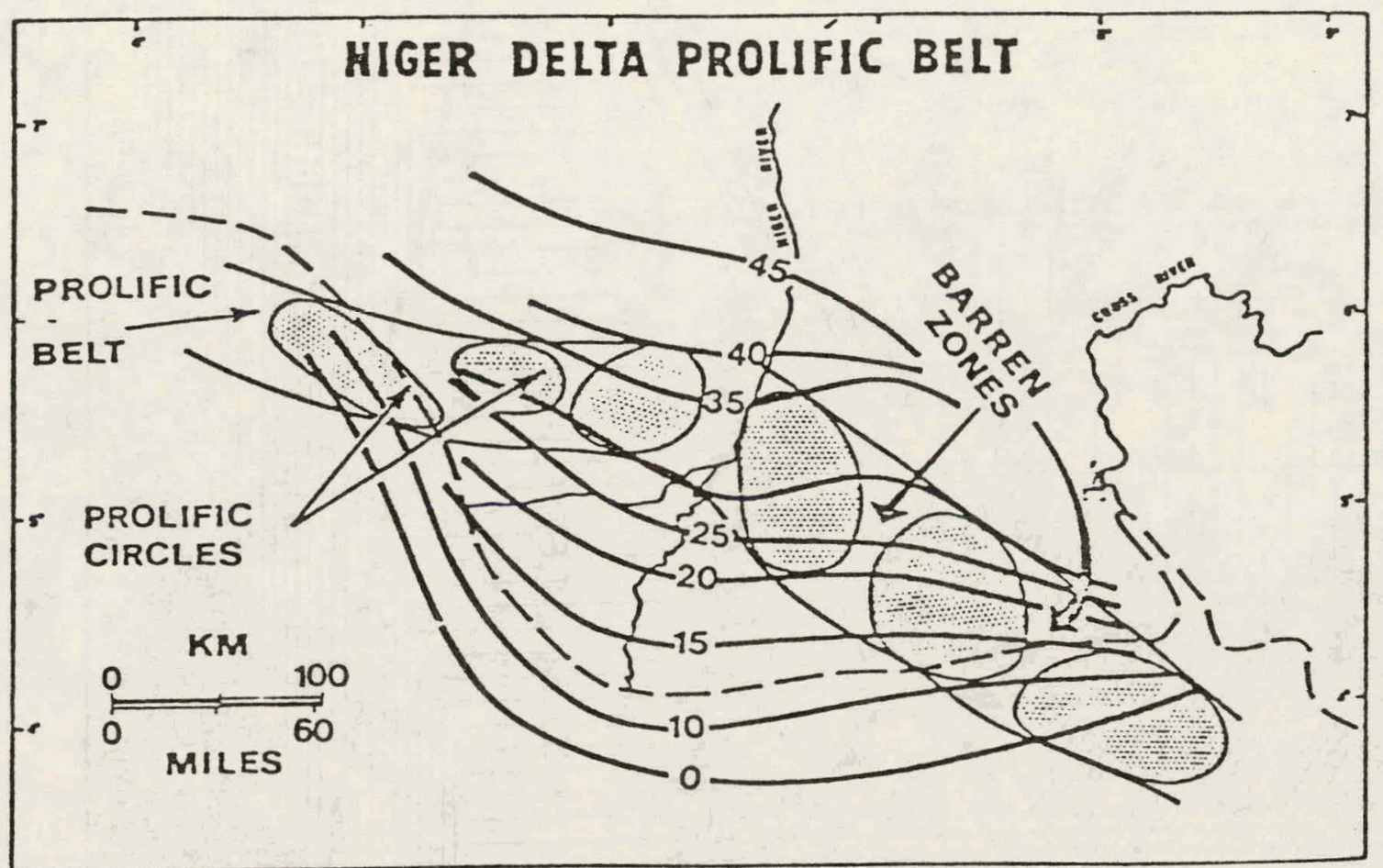

Figure 9. Successive stages of delta growth and the prolific belt. (Dailly, 1976). 


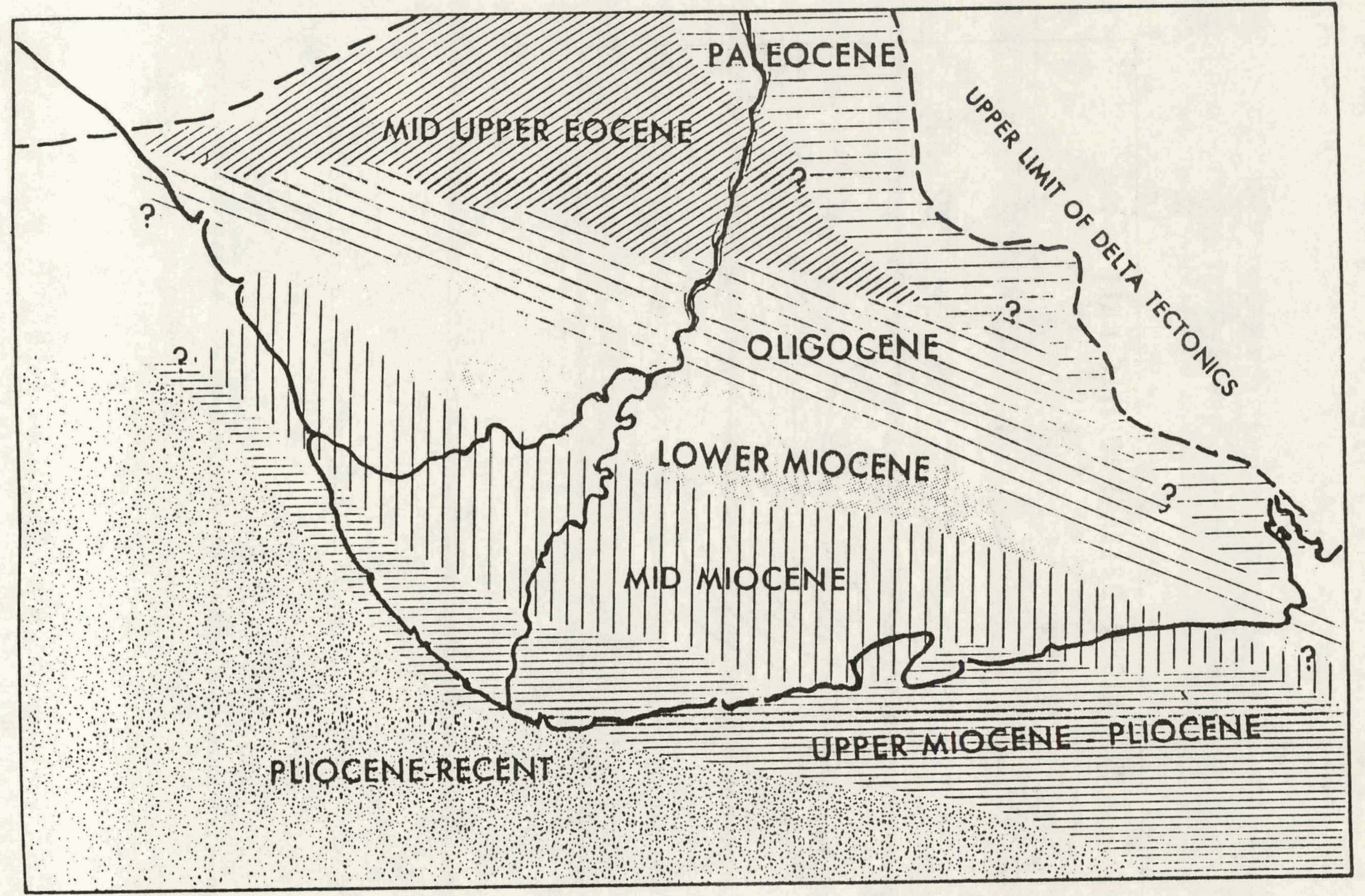




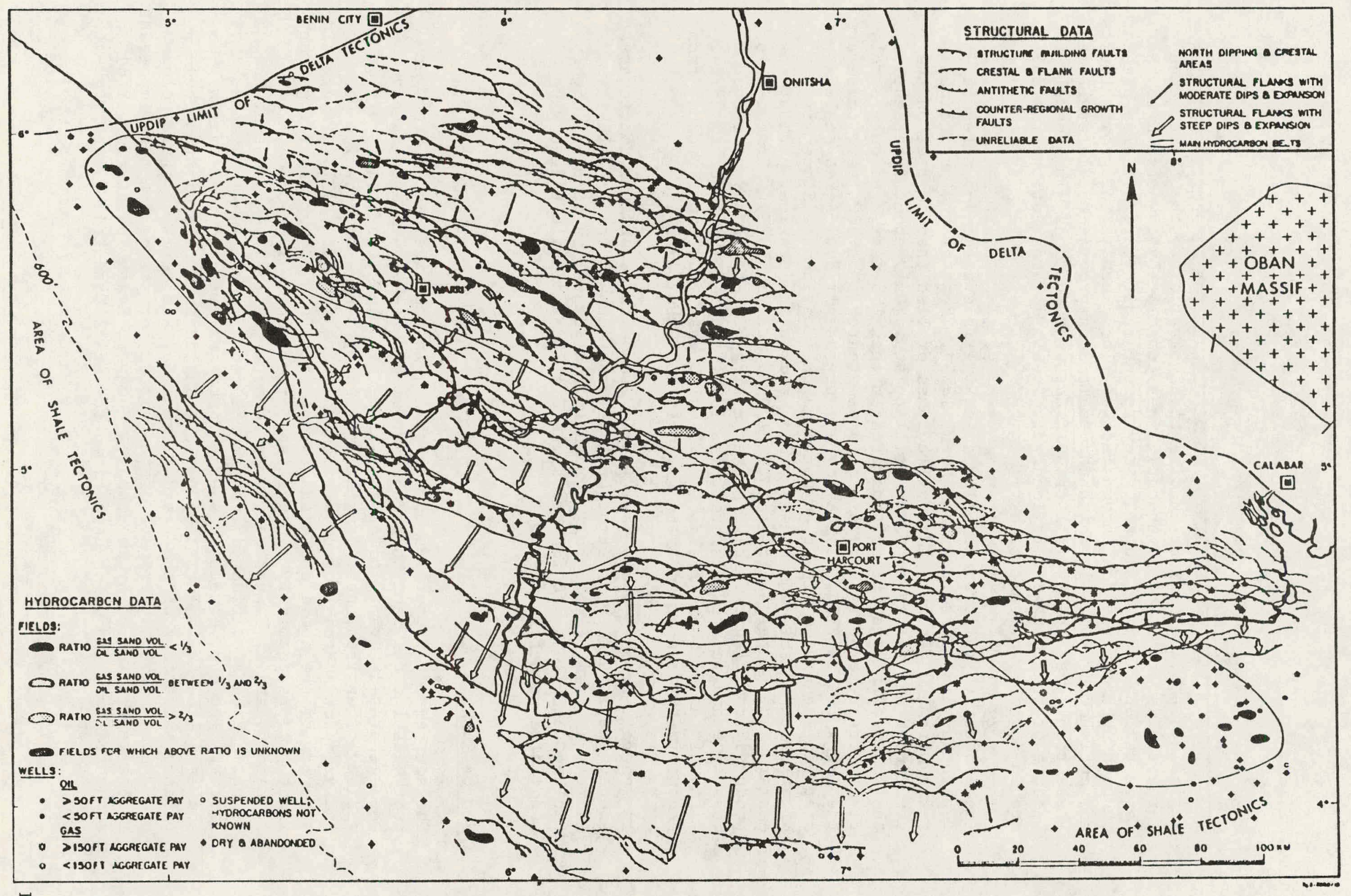
๒ా

in Figure 11. Regional fault trends and hydrocarbon distribution of the Niger Delta (Evamy and others, 1978). 
anticlines provide closure in directions parallel to the fault. The large fields are on rollover anticlines immediately downthrown to the large regional growth faults. Many "pure" fault traps are also present on both upthrown and downthrown blocks. These consist of growth faults and antithetic faults in which the fault does provide, the lateral seal. These trap types are typical of Gulf Coast production. In general, because of the southwest regional dip (seaward), most of the fields are in downthrown fault blocks.

The productive rollover anticlines in Nigeria average 4-5 miles in length and 2-3 miles in width (Owen, 1975). Most of the anticlinal reservoirs ( 70 percent) have oil columns of less than 50 feet on the structures not filled to their spill points. Only about 5 percent of the reservoirs have oil columns greater than 150 feet, and only a relatively few reservoirs have oil columns greater than 300 feet; the se are the large fields (Fig. 12) (Evamy and others, 1978). A few shale diapiric structures have been noted on the Continental slope off the Niger Delta (Mascle and others, 1973) and in the proximal part of the eastern Continental Shelf area (Evamy and others, 1978). Some oil is produced from diapiric shale or shale ridge-related traps near the coastline and in the offshore (Fig. 13) (Habarta, 1970; Merki, 1972). A few of the offshore fields (i.e., Ubit, Unam, and Utue) produce from unconformity truncation traps (Avbovbo and Ogbe, 1978).

In general, from an updip position in the delta toward the Continental Slope, the intensity of structural deformation and trap complexity increases, i.e., simple rollover anticlinal traps, to complex, highly faulted anticlines, to faulted shale diapirs and shale ridges with associated unconformities.

\section{Source Rocks}

The source-rock properties of the shales in the Niger Delta are "very poor" despite the fact that substantial amounts of oil and gas have been generated (Evamy and others, 1978). Shales deposited in a wide variety of environments, ranging from fully marine to paralic, were analyzed for source-rock properties and were found to be low in organic material of the humic and mixed types, which are precursors for gas and light oil, respectively. Unpublished research by $\mathrm{K}_{\text {. deGroot, }}$ K. Reiman, and T. T. Hartog (Evamy and others, 1978) showed that the Nigerian crudes originated from source rocks containing land-plant matter. The most effective source rocks are believed to be marine shales of the Akata Formation and the shales intercalated with the paralic sandstones of the Agbada Formation. In terms of shale volume, the Akata and the lower part of the Agbada Formations are more important in the generating of hydrocarbons. However, Evamy and others (1978) suggested that any oil generated in the Akata Formation had only a 


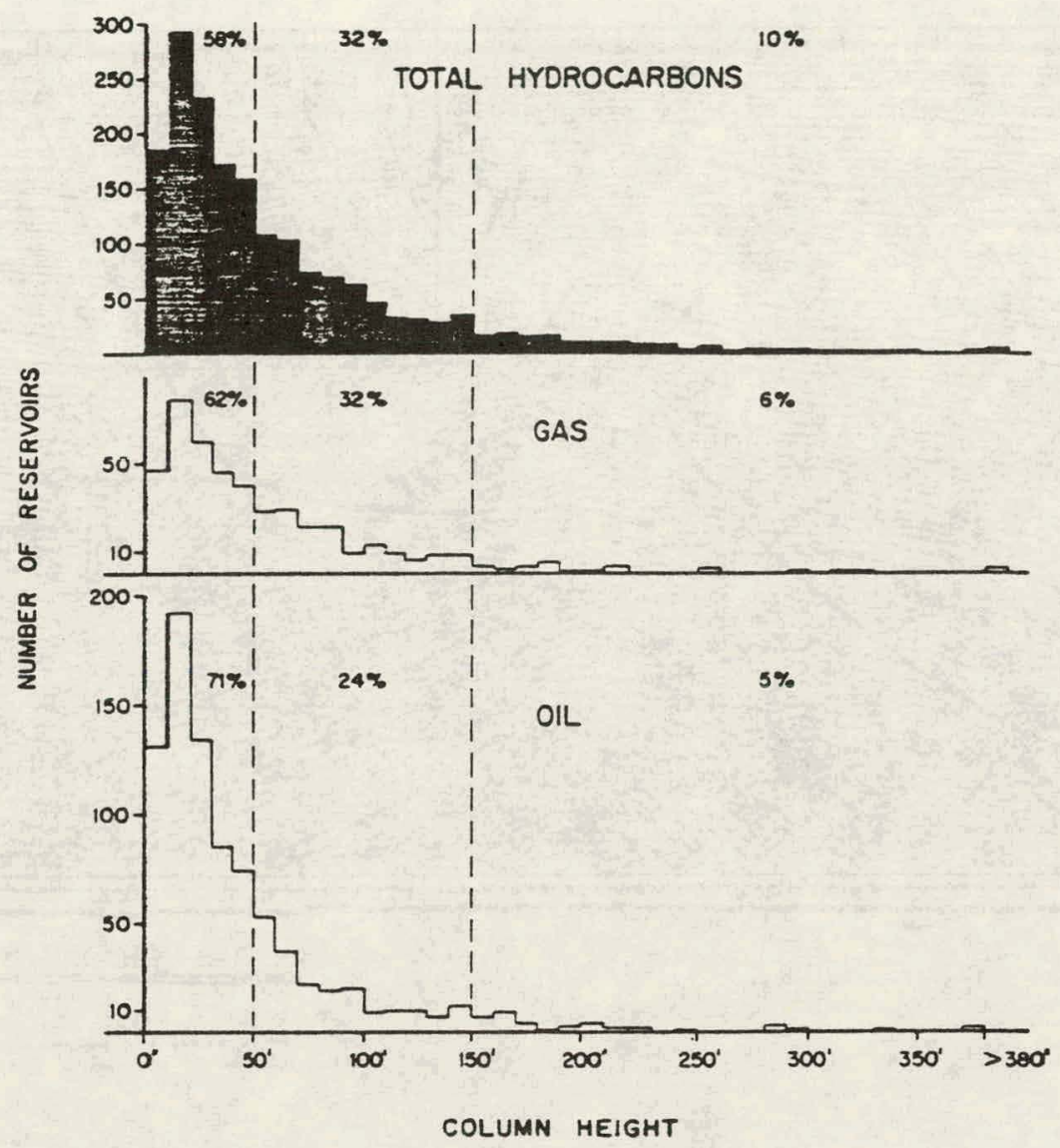

Figure 12. Hycrocarbon column heights, Niger Delta (Evamy and others, 1978). 


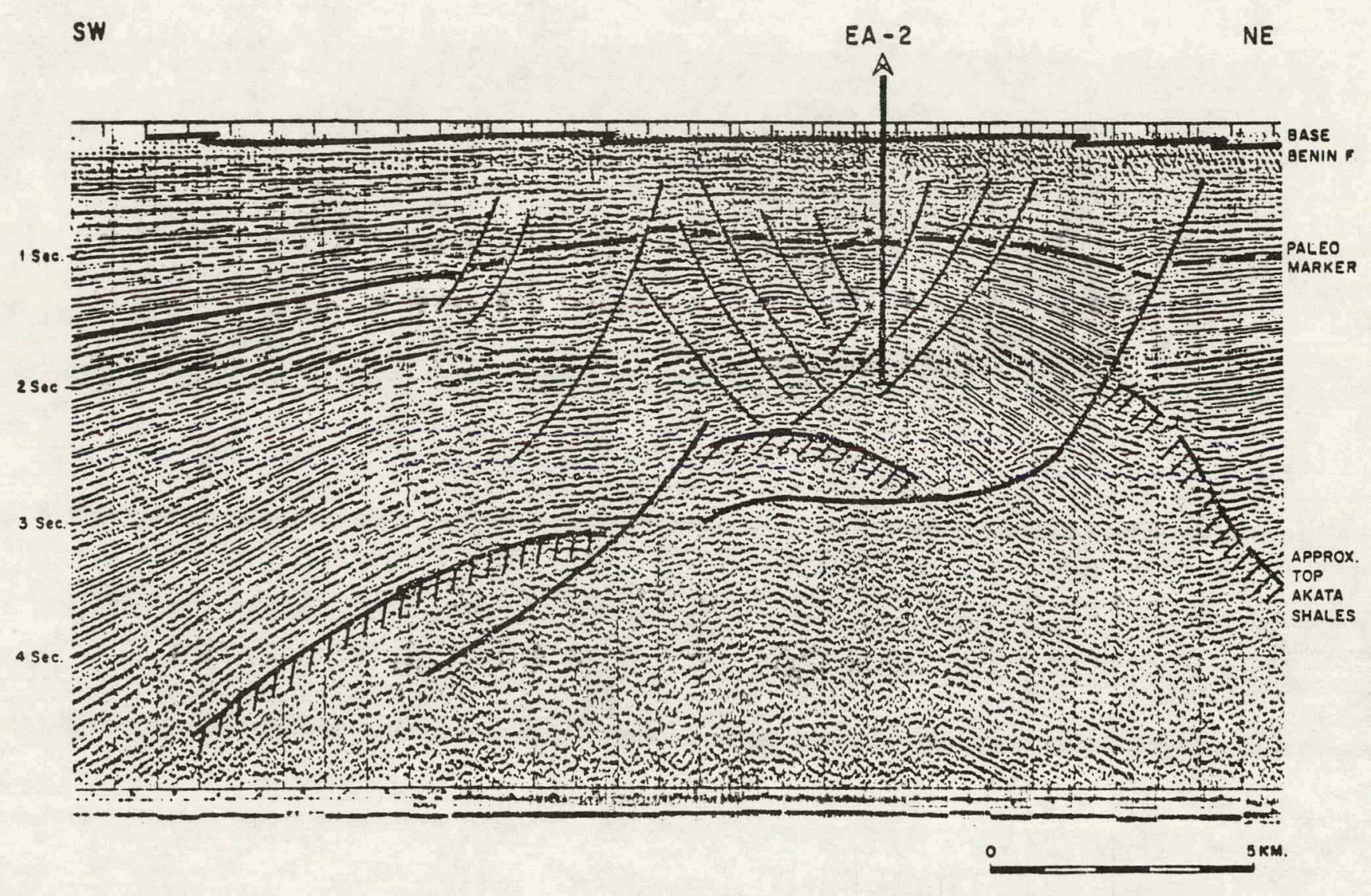

Figure 13. Seismic dip-section across shale diapir/ridge structure, offshore Nigeria (Merki, 1972). 
remote chance of finding its way into the overlying Agbada reservoirs because the faults at depth, within the Akata shales, are not effective migration paths.

Unpublished Shell research suggests that $240^{\prime} \mathrm{F}$ and $300^{\prime} \mathrm{F}$ represent the highest temperatures of the oil-generating zone and gas-generating zone, respectively, for Tertiary provinces (Evamy and others, 1978). Over a large part of the area west of the Niger and Nun Rivers, the top of the oil-generating zones lies well above the continuous shales of the Akata Formation, within the paralic and paralic-to-marine sequences of the Agbada Formation. In the east, however, the oil-generating zone generally lies entirely within the continuous marine shales of the Akata Formation. This is because the Agbada Formation is generally thinner over the eastern part of the delta. By tracing the oilgenerating zone through geologic time, Evamy and others (1978) found that the boundary between the paralic sequence and the continuous marine shales reached a level of oil maturity much later in the east than in the west. In the east, even at present, the fact that the Agbada Formation is only locally within the oil-generating zone implies that the eastern oil was derived not only late but also from source rocks mainly in the continuous marine shales. Evamy and others (1978) concluded that primary migration took place at a very late stage, certainly after most of the sedimentation and trap formation, and that the origin and migration of the oils in the west were earlier than the very late origin and migration of the east.

\section{Geothermal Gradients and Geopressuring}

The geothermal gradient varies from 1.0 ' $/ 100 \mathrm{ft}$ to $1.6^{\prime} \mathrm{F} / 100 \mathrm{ft}$ for the Tertiary of the Niger Delta to $3.0^{\prime} \mathrm{F} / 100 \mathrm{ft}$ in the Cretaceous rocks to the north (Fig. 14). In general, the geothermal gradients increase seaward and northward toward the basement areas from the center of the Niger Delta. Nwachukwu (1975) suggested that the higher thermal regime in the Cretaceous rocks of the Benue Trough is reflected in the relative scarcity of liquid hydrocarbons for the Cretaceous to the north of the delta. The value of the geothermal gradient appears to correlate inversely with sediment thickness. A low geothermal gradient occurs in the center of the delta where the thickness of sediments is maximum. Higher gradients to the northwest, north, and northeast correlate with the thinning of sediments toward the basement. The increase to the southeast may also reflect proximity to the "Cameroon hot spot" (Nwachukwu, 1975). The gradient increases offshore $\left(1.2^{\prime} \mathrm{F} / 100 \mathrm{ft}-1.6^{\prime} \mathrm{F} / 100 \mathrm{ft}\right)$ probably because of the thinning of sediments over basement highs. There is a close correlation between the 212 ' $\mathrm{F}$ isothermal contour and the depth to the top of the geopressures (Figs. 15a and 15b). This is probably due to the diagenesis of clay minerals and dewatering, causing the temperatures to rise and 


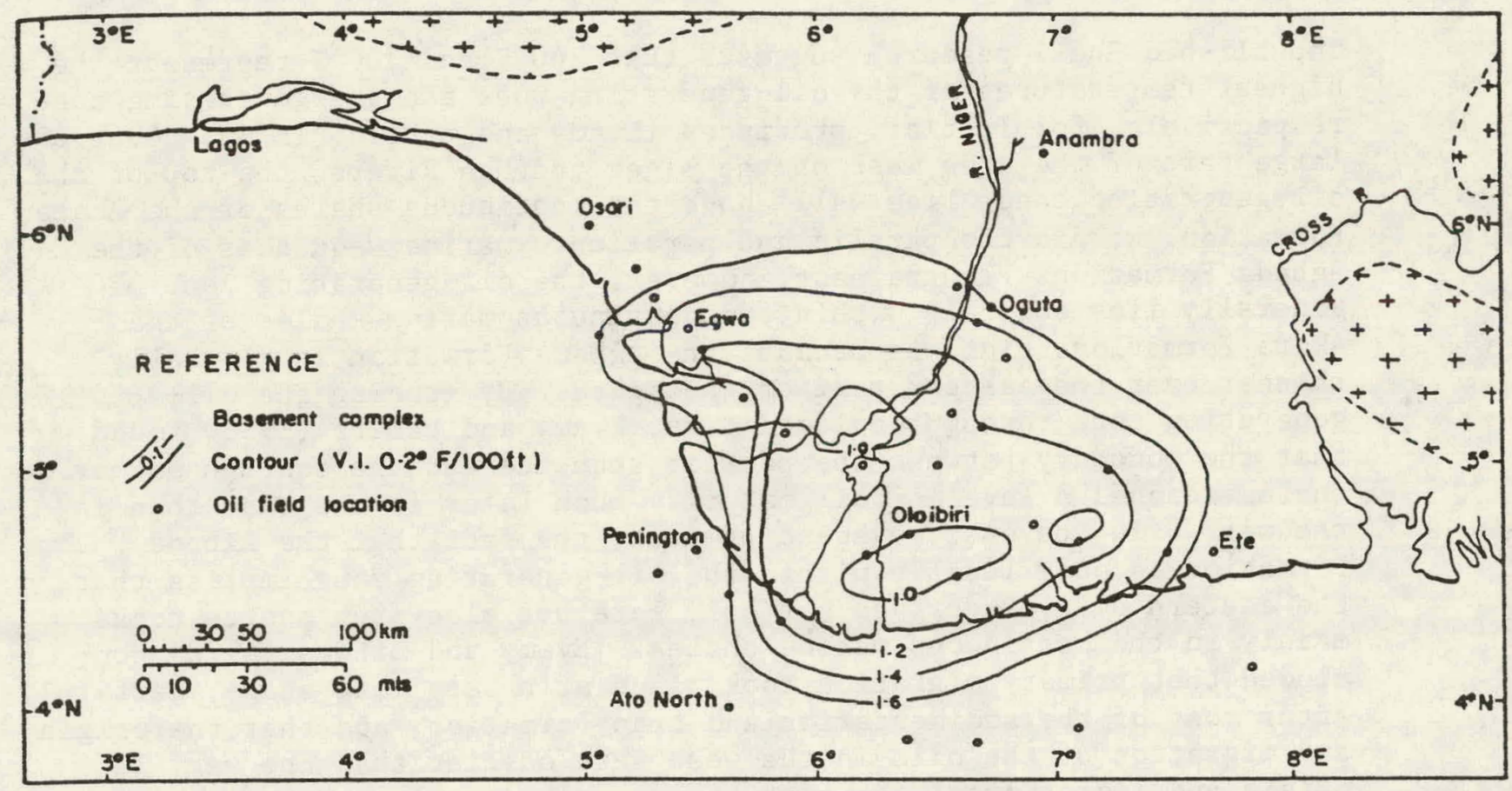

Figure 14. Corrected geothermal gradients in the Niger delta (Nwachukwu, 1975). 


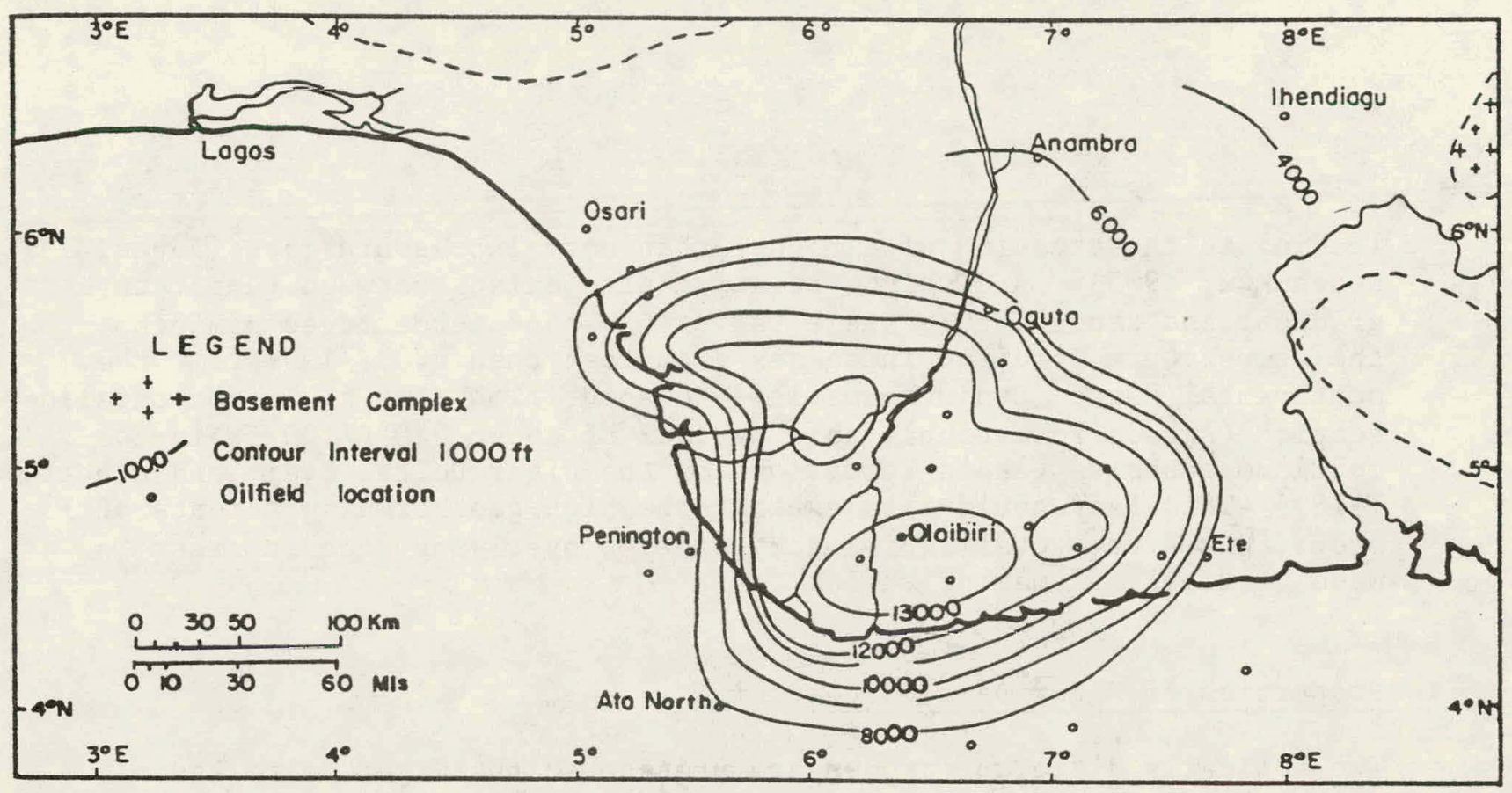

Figure 15a. Isogeothermal surface for $212^{\circ} \mathrm{F}$ (Nwachukwu, 1975).

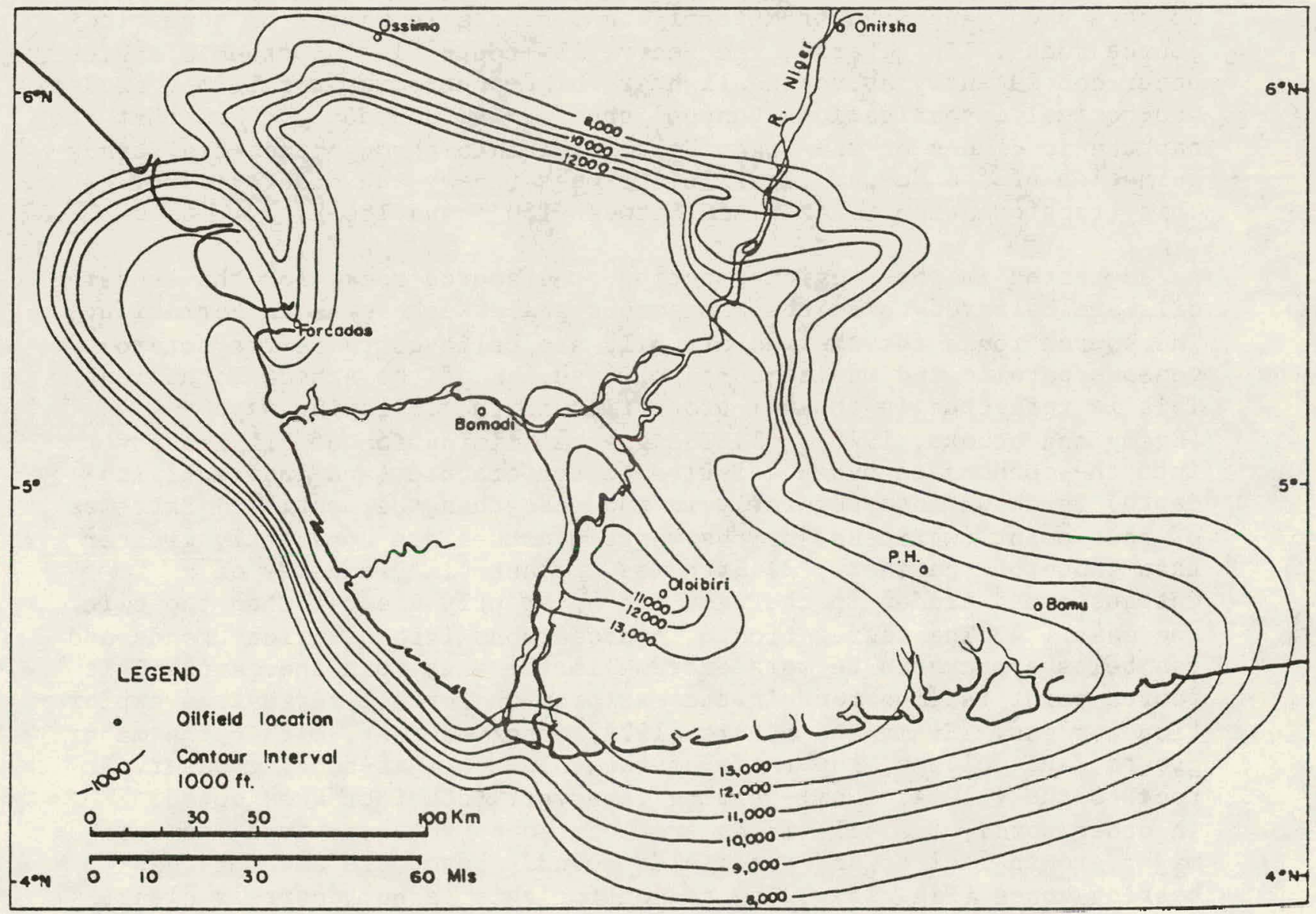

Figure 15b. Depth to the top of the overpressure zone Nwachukwu, 1975). 
leading to the creation of a higher than normal pressure zone (Jones, 1970; Nwachukwu, 1975). A distinct relation also exists between temperature gradient and sandstone to shale ratio. As sand percentages diminish, the temperature gradient increases from less than $1.0^{\circ} \mathrm{F} / 100 \mathrm{ft}$ in the continental sands (Benin Formation) to about $1.5^{\circ} \mathrm{F} / 100 \mathrm{ft}$ in the paralic section (Agbada Formation), to a maximum of about $3.0^{\circ} \mathrm{F} / 100 \mathrm{ft}$ in the continuous shales (Akata Formation) of the Niger Delta (Evamy and others,

1978). This fact could also explain the high geothermal gradients offshore, where the total sedimentary section overlying oceanic crust is made up mostly of marine shales.

\section{Properties of Niger Delta Crudes}

Two basically different crudes are present in the Niger Delta Basin, a light crude that is characteristically paraffinic and waxy with pour points in the range of about $20^{\circ} \mathrm{F}$ to $90^{\circ} \mathrm{F}$ and a medium crude that is dominantly naphthenic, nonwaxy, and has a pour point generally lower than $-13^{\circ} \mathrm{F}$ (Evamy and others, 1978). Waxy crudes are generally assumed to have been generated from terrigenous vegetable matter in nonmarine source rocks. In general, the heavy, low-pour-point naphthenic crudes occur consistently above the lighter, high-pour-point paraffinic crudes. Geochemical investigations (unpublished) by $K$. deGroot confirm that the naphthenic crudes of the Niger Delta orginiate through bacterial transformation of the deeper paraffinic crudes (Evamy and others, 1978). This transformation takes place between $150^{\circ} \mathrm{F}$ and $180^{\circ} \mathrm{F}$.

As suggested in the previous section, the source rocks for the eastern oils are believed to be the homogenous shales of the Akata Formation. The source rocks for the western oils are believed to be the heterogeneous paralic and marine-to-paralic shales of the Agbada Formation. This is reflected in the oil properties in the following ways

(Evamy and others, 1978): 1) The gradual diminution of oil gravity into the condensate range relative to temperature (and indirectly to depth) is shown more regularly in the east than the west. 2) Extremes of pour point (waxiness) of the western crudes are apparently greater than those of the east. 3) Extremes of tank-oil viscosity of untransformed crudes in the west are apparently greater than those in the east. 4) The segregation of hydrocarbons into oil-rich trends and gas belts appears to be more extreme in the west than the east. This fourth point is important in the exploration for oil versus the exploration for gas. Evamy and others (1978) observed that, within the major growth fault blocks, the ratio of the volume of gas-bearing reservoir rock to the volume of oil-bearing reservoir rock increases downdip. In other words, the oil fields are located on rollover traps on the major growth faults, and the fields downdip have more and more gasbearing zones (Fig. 16). The reason for this is not entirely clear; heterogeneity of source rocks, coupled with segregation during 


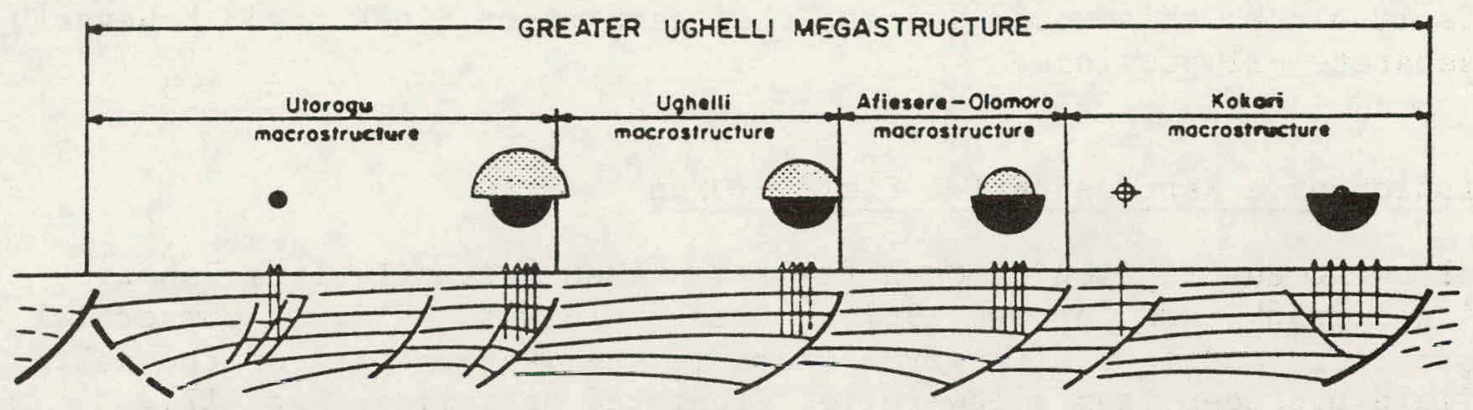

LEGEND
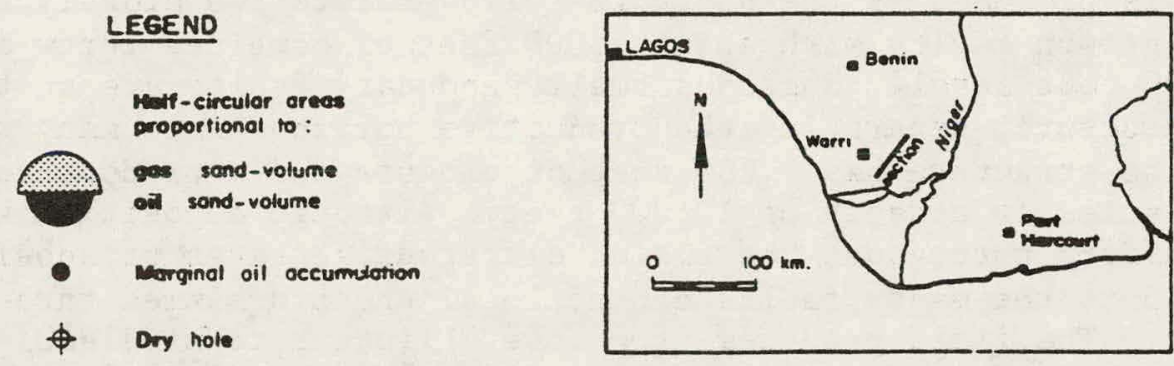

Figure 16. Distribution of oil and gas within a major fault block (Evamy and others, 1978). 
migration and remigration, is believed to be responsible for the observed hydrocarbon distribution. Because this phenomenon repeats itself for each fault block, this would suggest that each major block trend behaves as a separate oil province.

\section{Description of a Representative Field - Okan}

The following description of Okan field is taken primarily from Habarta (1970) and Fränkl and Cordry (1967). Okan field was the first commercial offshore field and is 8 miles from shore in the western part of the delta * Okan field produces from a low-relief elongated anticline (Fig. 17). The trap is produced by the northdip rollover into two closely spaced regional growth faults with about 5,000 feet of combined throw at about the 10,000 foot level. Numerous small secondary faults are on the crest of the structure, separating the productive horizons into many reservoirs. The structure has 1,200 feet of closure and a productive area of 6,000 acres at a depth of 10,000 feet. Although deposition was fairly uniform throughout the field, differential rates of subsidence downthrown to the major faults caused local unconformities throughout the field. The field produces from lower Pliocene to middle Miocene sands of the Agbada Formation. Oil columns in the larger reservoirs are greater than 200 feet. Gas caps are present in most of the oil reservoirs, although there are also nonassociated gas sands. Porosities in the oil sands average 30 percent, and the permeabilities are as high as 5 darcys. In discussing the probable origin of the hydorcarbons in Okan, Fränkl and Cordry (p. 208, 1967) wrote:

"The derivation of the hydrocarbons in the multiple reservoirs of the Okan field should probably be attributed to the shales immediately adjacent to any particular sand body. Evidence of this includes random (though not marked) variations in gravities, sharp differences in gas, oil, and water content from sand to sand in vertical vector."

This origin of hydrocarbons is probably typical for most of the fields in the western delta.

Okan crude has the following average properties:

Gravity

Viscosity, SUV

Flash, P-M

Pour point

Color

Sulphur

Salt as $\mathrm{NaCl}$

Refractive index

\author{
$34.6^{\prime}$ API \\ Sec. $100^{\prime} \mathrm{F} ; 37.8$ \\ Below $60^{\prime} \mathrm{F}$ \\ $-25^{\prime} \mathrm{F}$ \\ Greenish-brown \\ $0.15 \%$ \\ 16/1,000 bbl: 5 \\ 1.4816
}


The average hydrocarbon analysis:

$\begin{array}{lrr} & \text { \% wt. } & \% \text { vol. } \\ \text { Ethane } & 0.07 & 0.16 \\ \text { Propane } & 0.51 & 0.86 \\ \text { i - Butane } & 0.38 & 0.57 \\ \text { n - Butane } & 0.91 & 1.33 \\ \text { i - Pentane } & 0.86 & 1.17 \\ \text { n - Pentane } & 0.83 & 1.12 \\ \text { C and heavier } & 96.44 & 94.79\end{array}$

The cross section through Okan (Fig. 17) also illustrates many of the points previously discussed on the typical Niger Delta geology: 1) roll of strata into the fault on the downthrown block, 2) increase of the throw of the fault with depth, 3) expansion of the stratigraphic section on the downthrown block, 4) the shift of the structural axis in a downdip direction with depth, and 5) the expansion of the stratigraphic section (i.e., age of maximum fault movement) is progressively younger in a downdip direction.

\section{Geological Observations and Conclusions}

- The stratigraphy, age of rocks, trap type, production characteristics, reservoir rock properties, and field-size distributions of the Niger Delta Basin are very similar to those of the U.S. Gulf Coast Basin.

- The Agbada Formation that produces in Nigeria is the same facies equivalent that produces in the U.S. Gulf Coast, although in the Gulf Coast, production is designated by "age of productive trend," not by formation name.

- As in the U.S. Gulf Coast, Nigerian Miocene-age rocks contain the bulk of the reserves.

- Most of the large fields produce from rollover anticlines associated with large regional growth faults. The smaller fields are generally associated with smaller growth faults and nongrowth faults.

- A close correlation exists between the throw of a fault and reserves.

- In a downdip direction within major regional growth fault blocks, the chance of discovering gas is greater than the chance of discovering oil. The large oil fields are immediately downthrown to the major regional growth faults. 


\section{UKAN FIELD}

STRUCTURE MAP TOP H5 SAND (TOP Upper Miocene)

Contour interval: $100 \mathrm{ft}$ DP. sea level
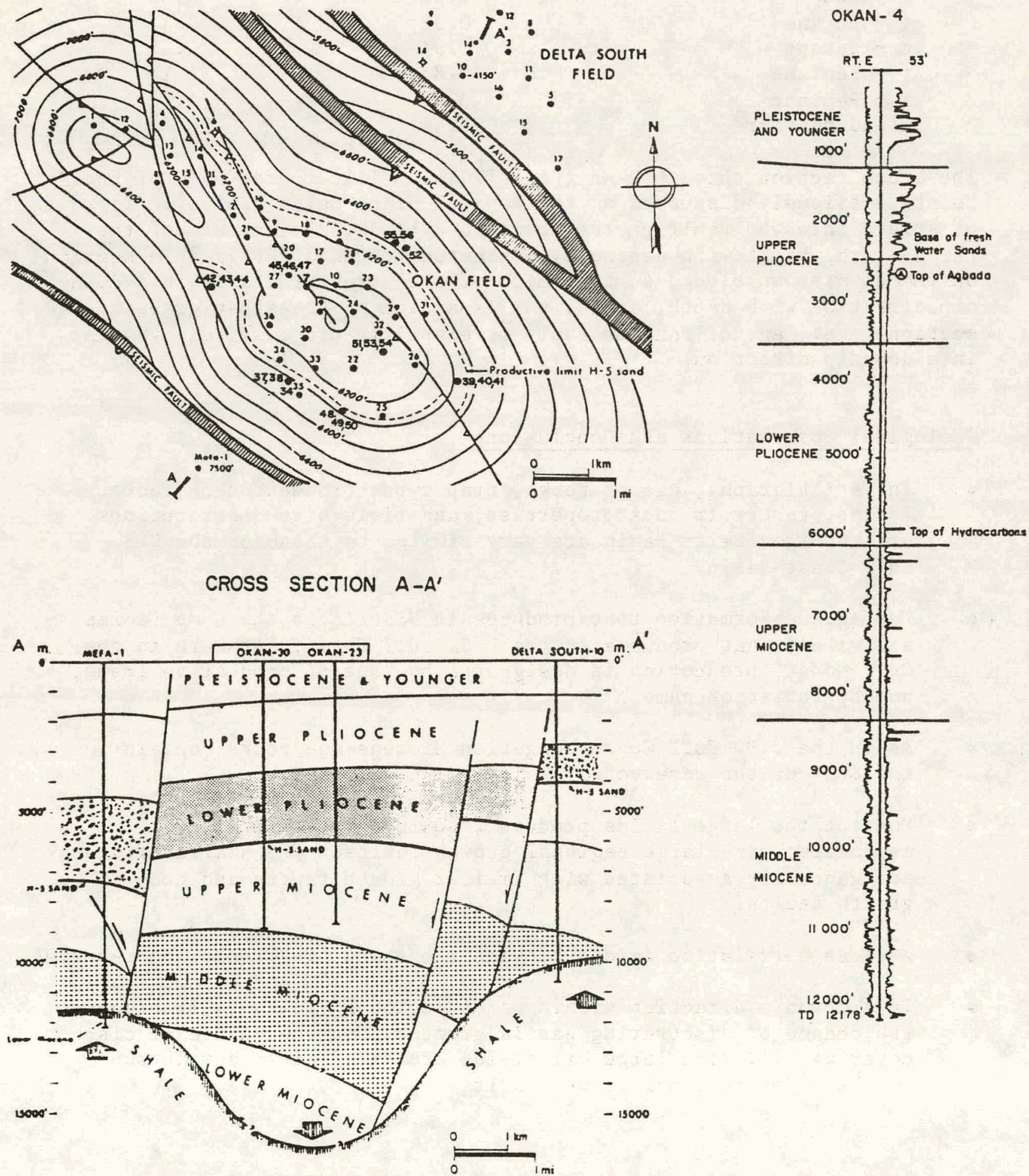

Figure 17. Structure map, cross section, and type $10 \mathrm{~g}$ from 
- A large part of the lower central delta, both onshore and offshore, contains predominantly small fields, where gas, rather than oil, is dominant. Future discoveries of large gas fields might be expected in this area.

- In general, structures become increasingly more complex in a downdip (seaward) direction. Hence, more exploratory wells would be needed downdip to evaluate traps and more development wells to produce the hydrocarbons. Greater reserves would be required for commercial use.

- From the coast to the Continental Slope, the main producing formation, the Agbada, becomes progressively thinner. The bulk of the total section offshore is shale, where we have less chance of penetrating quality reservoir rocks.

- In general, the total offshore area is probably more gas-prone than oil-prone, and most of the future discoveries, both onshore and offshore, will be gas.

- Most of the potential traps upthrown to major regional growth faults offshore will not contain reservoir rocks.

- Marginal to the main depocenter of the central delta, rollover anticlines will become less important as a trap type, and "pure" fault traps, low relief anticlines, and diapirs will become more important.

- The depth to the top of the overpressured zone is relatively shallow $(8,000 \mathrm{ft}-13,000 \mathrm{ft})$. Offshore, the depth is shallower than onshore and probably limits the total section available for large oil reserves.

- In general, the physical properties of the Niger Delta crudes are more varied in the west than in the east.

The Benin Formation and the Akata Formation have limited exploration potential.

- The future potential for methane from geopressure formation waters appears to be greater per unit volume of sediment in Nigeria than in the Gulf Coast because of the higher geothermal gradient $\left(1.4^{\circ} \mathrm{F} / 100 \mathrm{ft}-1.6^{\circ} \mathrm{F} / 100 \mathrm{ft}\right.$ ) and lower salinities (less than $40,000 \mathrm{ppm})$ in the Niger Basin. 


\section{$\underline{\text { References }}$}

Aliu, U., and Novelli, L., 1974, Outlines of Niger Delta geology, Well evaluation conference: Nigeria. Publ. Services Techniques, Schlumberger, France, P. I-1 to I-5.

Avbovbo, A. A., 1978, Tertiary 1ithostratigraphy of Niger Delta: AAPG Bul1., v. 62, no. 2, p. 295-306.

Avbovbo, A. A., and Ogbe, F.G.A., 1978, Geology and hydrocarbon productive trends of the southern Nigerian basin: $0 i 1$ and Gas Journal, Nov. 27, 1978, p. 90-93.

Burke, K. C., Dessauvagie, T.F.J., and Whiteman, A. J., 1970, African Geology, Univ. Ibadan, Niger1a, p. 187-205.

Dailly, G. C., 1976, Pendulum effect and Niger Delta prolific belt: AAPG Bull., v. 60, no. 9, Sept. 1976, p. 1543-1575.

Evamy, B. D., Haremboure, Y., Kamerling, P., Knaap, W. A., Molloy, F. A., and Rowlands, P. H., 1978, Hydrocarbon habitat of Tertiary Niger Delta: AAPG Bull., v. 62, no. 1, Jan. 1978, p. 1-39.

Fränkl, F. J., and Cordry, E. A., 1967, The Niger Delta oil province: Recent developments onshore and offshore: 7 th World Petroleum Congress Proc., v. 2, p. 195-209.

Habarta, A. W., 1970, offshore developments with special reference to Okan Field, Nigeria: in Dessauvagie, T.F.J., and Whiteman, A. J. (eds.), African Geology, University of Ibadan Publ., Nigeria, p. 291-300.

Jones, P. H., 1970, Geothermal resources of the northern Gulf of Mexico basin: United Nations Symposium on the development and utilization of geothermal resources, Pisa, v. 2, p. 14 .

Mascle, J. R., Bornhold, B. D., and Renard, V., 1973, Diapiric structures of Niger Delta: AAPG Bull., v. 57, p. 1672-1678.

Merki, J. P., 1972, Structural geology of the Cenozoic Niger Delta: in African Geology, structural geology, Ibadan, Nigeria, Dept. Geology Ibadan Univ., p. 635-646.

Murat, R. C., 1970, Stratigraphy and paleogeography of the Cretaceous and lower Tertiary in southern Nigeria: in Dessauvagie, T.F.J., and Whiteman, A. J. (eds.), African Geology, University of Ibadan Publ., Nigeria, p. 251-266. 
Nwachukwa, S.0.0., 1975, Geothermal regime of southern Nigeria: in Second United Nations symposium on the development and use of geothermal resources Proc., May 1975, p. 205-212

Owen, E. W., 1975, Central and southern Africa: in Owen, E. W. (ed.), Trek of the oil finders: a history of exploration for petroleum: AAPG Memoir 6, Chapter 22, Part VI, p. 1483-1490.

Short, K. C., and Stäuble, A. J., 1967, Outline of geology of Niger Delta: AAPG Bull., v. 51, p. 761-779.

Weber, K. J.,.1971, Sedimentological aspects of the oil fields in the Niger Delta: Geol. en Mijnb, v. 50, no. 3, p. 559-576.

Weber, K. J., and Daukoru, E., 1975, Petroleum geology of the Niger Delta: in Ninth World Petroleum Congress Panel Discussion 4, Paper 1, W. P. C. Publ., Tokyo. 
APPENDIX C

$\begin{array}{cc}\text { GEOLOGIC TIME SCALE } & \text { C. } 1 \\ \text { DEFINITIONS } & \text { C. } 2 \\ \text { REFERENCES } & \text { C. } 4\end{array}$


GEOLOGIC TIME SCALE

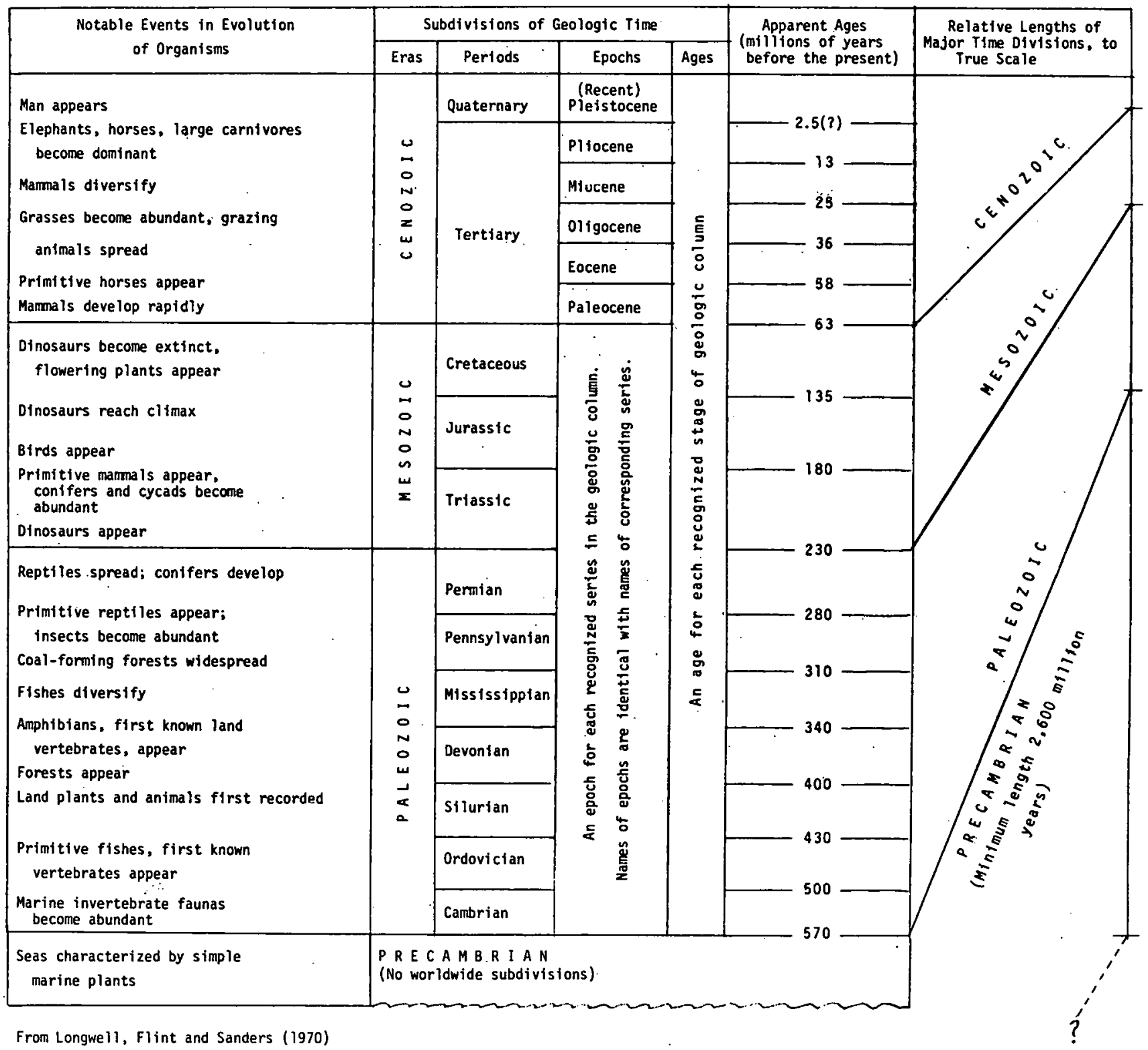


APPENDIX E

DEFINITIONS

\section{Proved Reserves:}

Estimated quantities which geological and engineering data demonstrate with reasonable certainty to be recoverable in future years from known oil and gas reservoirs under existing economic and operating conditions.

Reservoirs are considered proven if economic produci-: bility is supported by either actual production or conclusive formation tests. The area of a reservoir considered proved includes: (1) that portion delineated by drilling and defined by gas-oil, gas-water, or oil-water contacts, if any; and (2) the immediately adjoining portions not yet drilled but which can be reasonably judged as economically productive on the basis of available geological and engineering data. In the absence of information on fluid contacts, the lowest known structural occurrence of hydrocarbons controls the lower proved limit of the reservoir.

Reserves of crude oil which can be produced economically through application of improved recovery techniques are included in the "proved" classification when successful testing by a pilot project or the operation of an installed program in the reservoir provides support for the engineering analysis on which the project was based.

Reserve estimates are prepared for total recoverable natural gas, nonassociated gas and associated-dissolved gas.

Indicated reserves: those quantities believed to be recoverable under existing secondary and tertiary recovery technology and economics, but where current technology has not yet been applied. Because advanced recovery techniques have not been needed or applied in. the conventional production of gas, there are no

"indicated gas reserves" categories. 
Some oil and gas remains to be discovered in known fields through drilling to reservoirs at greater depths and beyond the proved boundaries of those fields. The portion of such resources which is believed to be recoverable once found is known as inferred reserves.

\section{Resource:}

A concentration of naturally-occurring solid, liquid or gaseous materials in or on the earth's crust. in such form that economic extraction of a commodity is currently or potentially feasible.

The recoverable resource is that portion of the resource which will, when discovered, become new reserves. Thus resource estimates, like reserves, have technological: and economic, as well as geologic, implications. A more accurate appraisal of remaining resources can only be achieved by expanded exploration of frontier areas, orderly marshalling and analysis of data generated by exploration in new and oil areas and development. of discovered fields.

The following definitions are used by most of the oil industry:

A Proved field has been drilled, has known reserves which can be produced at a profit. A Potential field, even though indicated by an exploratory well, may not yet be economically producible. A Probable field looks good enough to risk a wildcat well, but valuable: reserves are not yet found. A Possible field may hold undiscovered reserves, based on geological indications, but the information is still insufficient. A speculative field is largely unexplored, what little is known seems encouraging but actual oil and/or gas reserves after exploration may range from "enormous" through "uneconomic" to "non-existent."

\section{References :}

API Technical Report No.: 1, Second Edition, 1976

Federal Energy Administration Initial Report, June 1975

Standard Oil Co. of California, 1975 


\section{REFERENCES}

Aborbo, Akpoyovbike A. "Tertiary lithology of the Niger Delta," 1978, Am. Assoc. Petroleum Geologists Bulletin, v. 62, no. 2, pp. 295-306.

-- and Ogbe, Freedom, G.A. "Geology and hydrocarbon productive trends of southern Nigeria Basin," Oil and Gas Journal, Nov. 27, 1978, pp. 90-93.

DeGolyer and MacNaughton, Twentieth Century Petroleum Statistics, 1977, Dallas, Texas, pp. 1-16.

Evamy, B.D., Harembourc, J., Kamerling, P., Knaap, W.A., Molloy, F.A., and Rowlands, P.H. "Hydrocarbon habitat of Tertiary Niger Delta," Jan. 1978, Am. Assoc. Petroleum Geologists Bull., v. 62, no.1, pp. 1-39, 12-13, 16-17.

Frankl, E.J. and Cordry, E.A. "The Niger Delta oil province: recent developments onshore and offshore," 1967, Seventh World Petroleum Congress, Proceedings, v. 2, Origin of Oil, Geology and Geophysics, pp. 195-209.

Hospers, J. "Gravity field and structures of the Niger Delta, Nigeria, West Africa," 1965, Geological Society of America Bulletin, v. 76, pp. 407-422.

---. "The geology of the Niger Delta area," Natural Environment Research Council, Institute of Geological Sciences, Rpt. no. 70/16 in the Geology of the East Atlantic Continental Margin, 4 Africa, 1971, pp. 123-142.

Mascle, J.R., Bornhold, B.D., and Renard, V. "Diapiric structures of Niger Delta," 1973, Am. Assoc. Petroleum Geologists Bull., v. 57, pp. 1572-1678.

Miller, Betty M. "The evolution in the development of the petroleum resource appraisal procedures in the U.S. Geological Survey and a summary of current assessments for the United States," 1979, Society of Petroleum Engineers of AIME, SPE no. 7720, pp. 79-90.

Oil and Gas Journal. "World oil flow gains slightly, reserves dip," December 25, 1978, p. 103. 
Petroconsultants, S.A. World Field Files, International Energy Services, 1978, Geneva, Switzerland.

Schatzl, L.H. Petroleum in Nigeria, 1969, Oxford University Press, Idaden, pp. I-45, 198-210.

Short, K.C. and Stauble, A.J. "Outline of geology in Nigeria Delta," Am. Assoc. Petroleum Geologist Bull., v. 51, no. 5, pp. 761-779.

Weber, K.J., "Sedimentological aspects of oil fields in the Niger Delta," Geologie en Mijnbouw, 1971, v. 50(3), pp. 559-576.

--- and Daukoru, E. "Petroleum Geology of the Niger Delta," Ninth World Petroleum Congress, Proceedings, 1975, v. 2, Geology, pp. 209-221. 
APPENDIX D

FESAP-Nigeria

Statistical Data

Historical Resume of Oil Field production

through 1977 
APPEÑDix D

H1storical Resume of 011 Field Productionl

(1000 barrels)

NIGERIA :

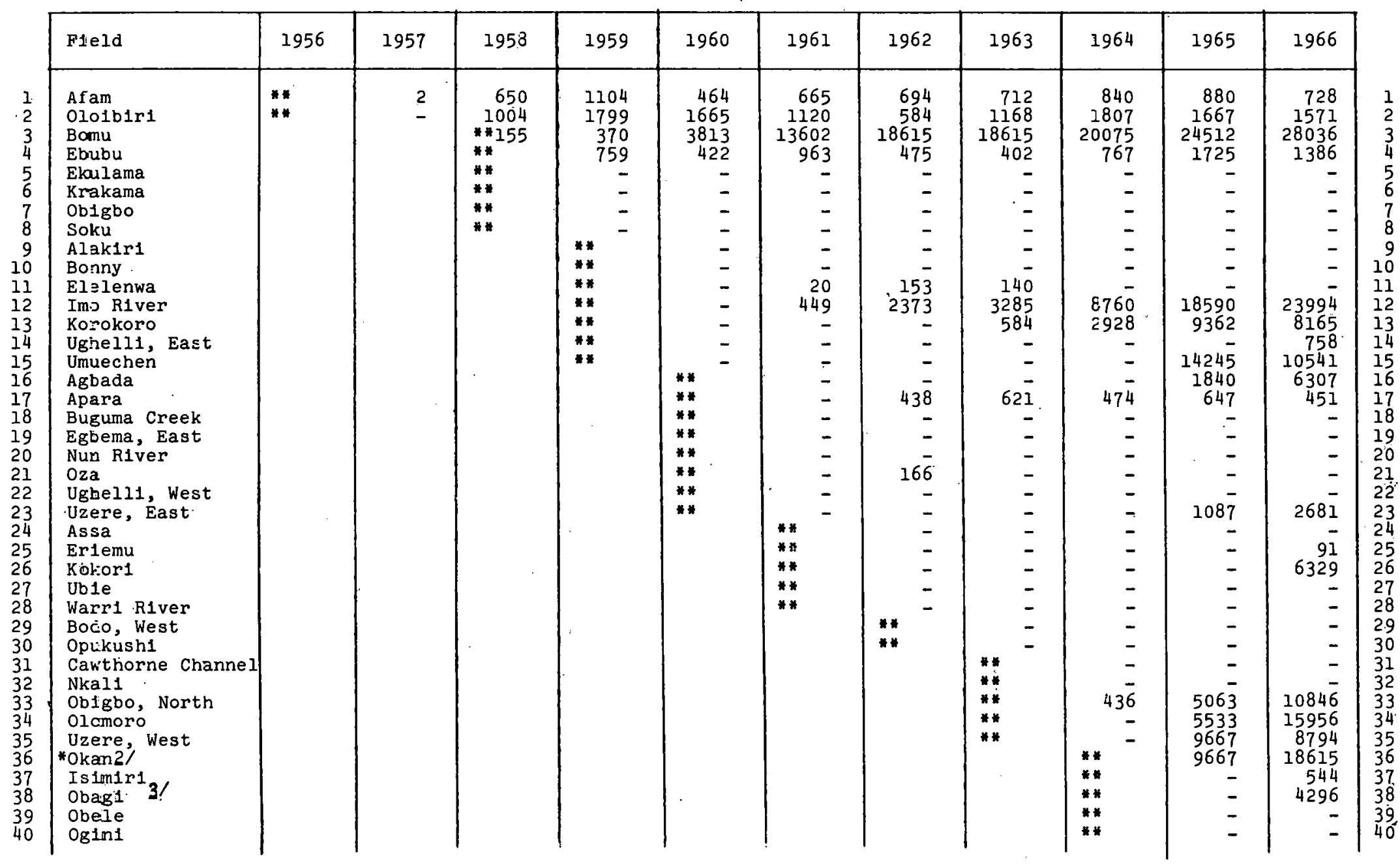

* Offshore field.

* Year of discovery. 
APPENDIX D

Historical Resume of 011 Fleld Productionl/ (1000 barrels)

NIGERIA

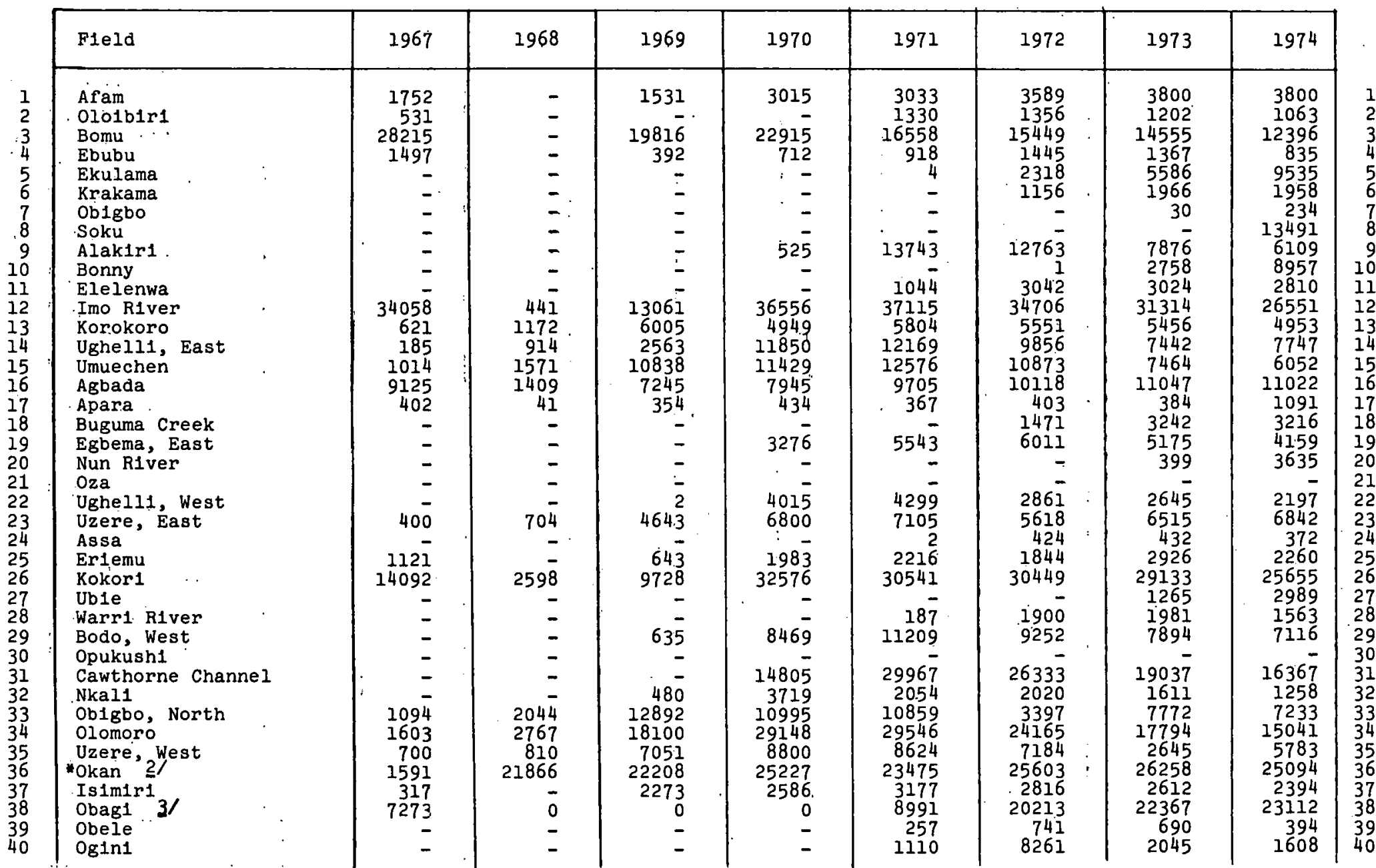

*:Offshore fleld.

* Year of discovery. 
Historical Resume of 011 Field Productionl/

NIGERTA : (1000 barrels)

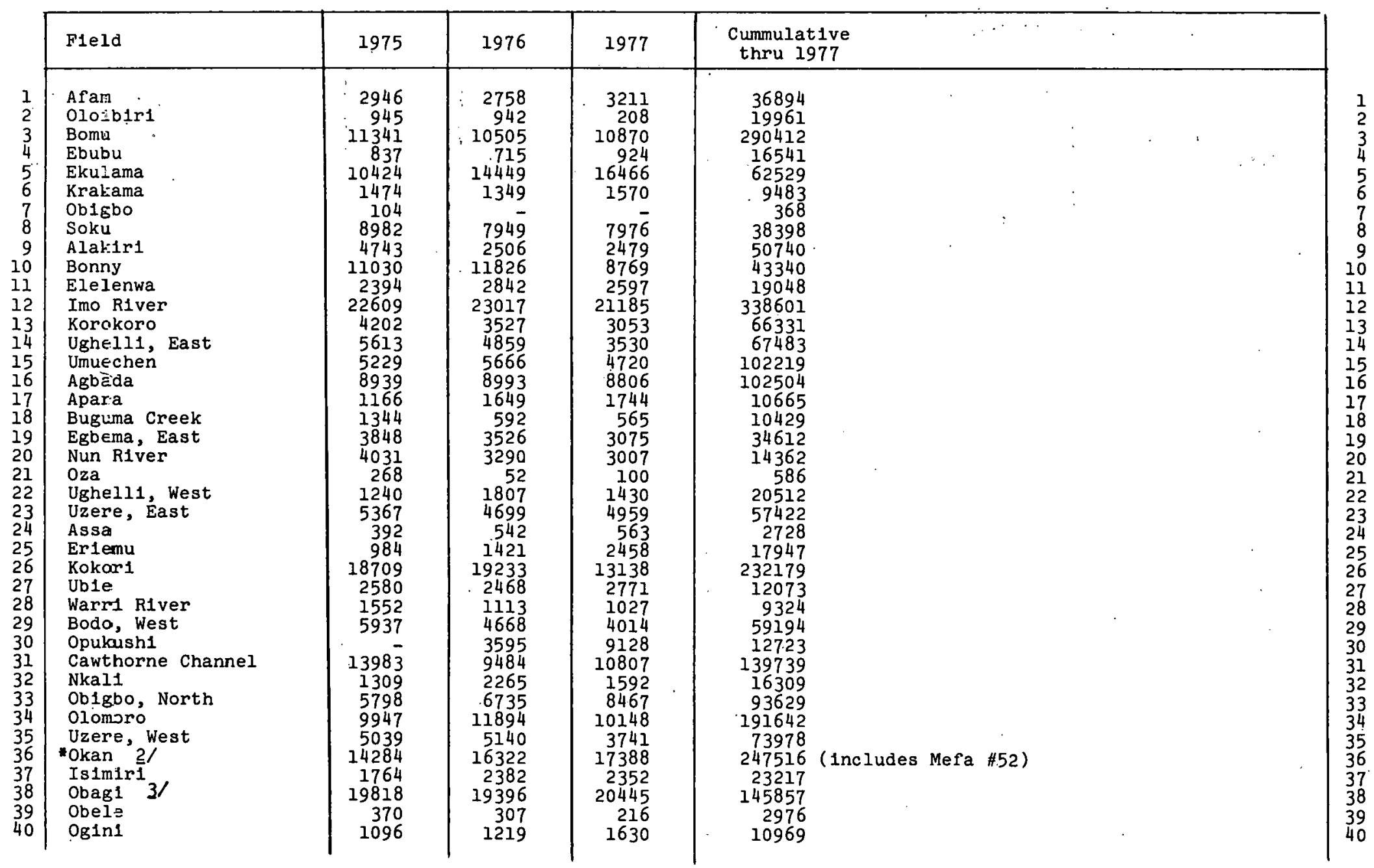

- Offshore field.

* Year of discovery. 
APPENDIX D

Historical Resume of 011 Field Froductionl/ NIGERIA :

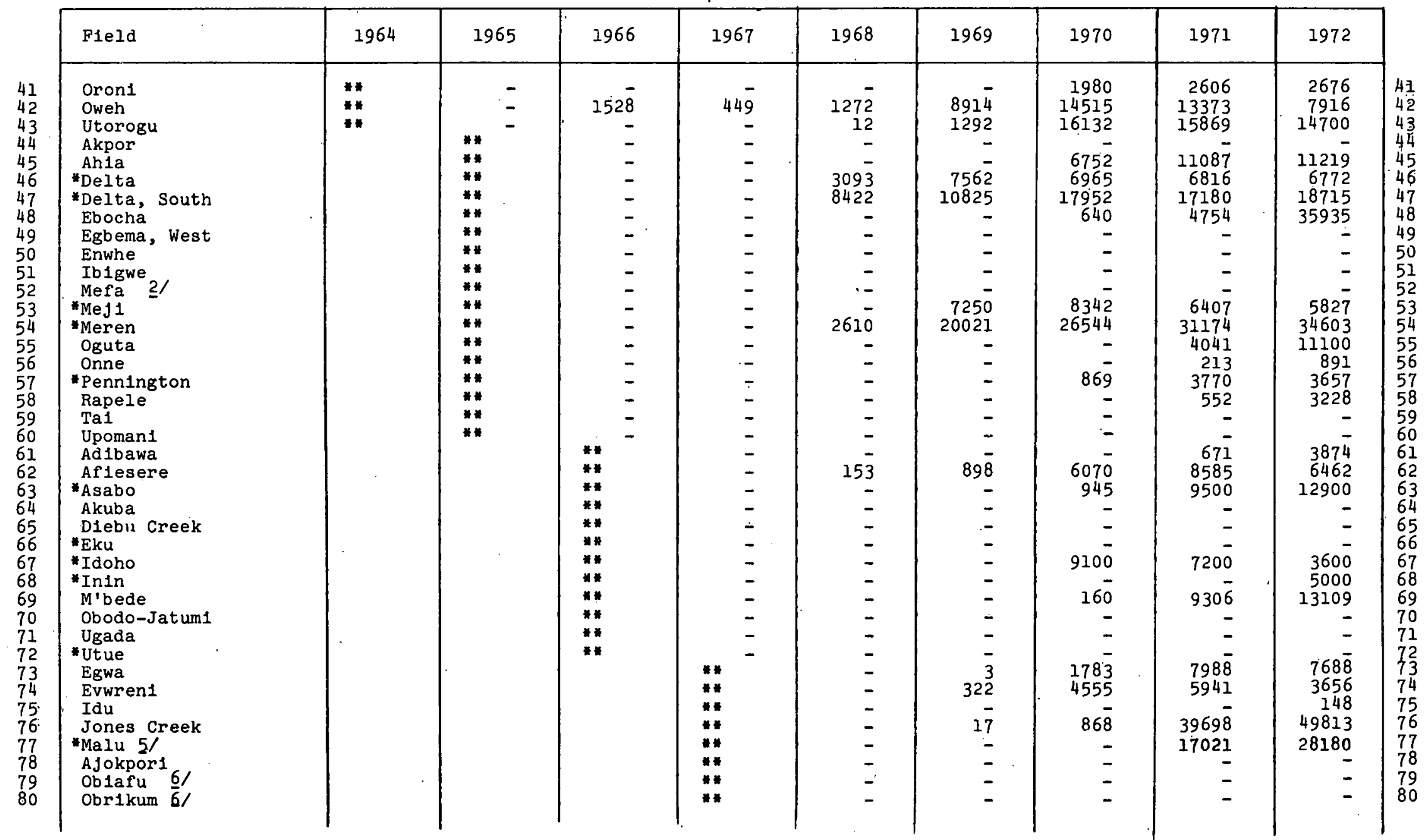

* Offshore fleld.

* Year of discovery. 
H1storical Resume of 011 'F1eld Production (1000 barrels)

NIGERTA :

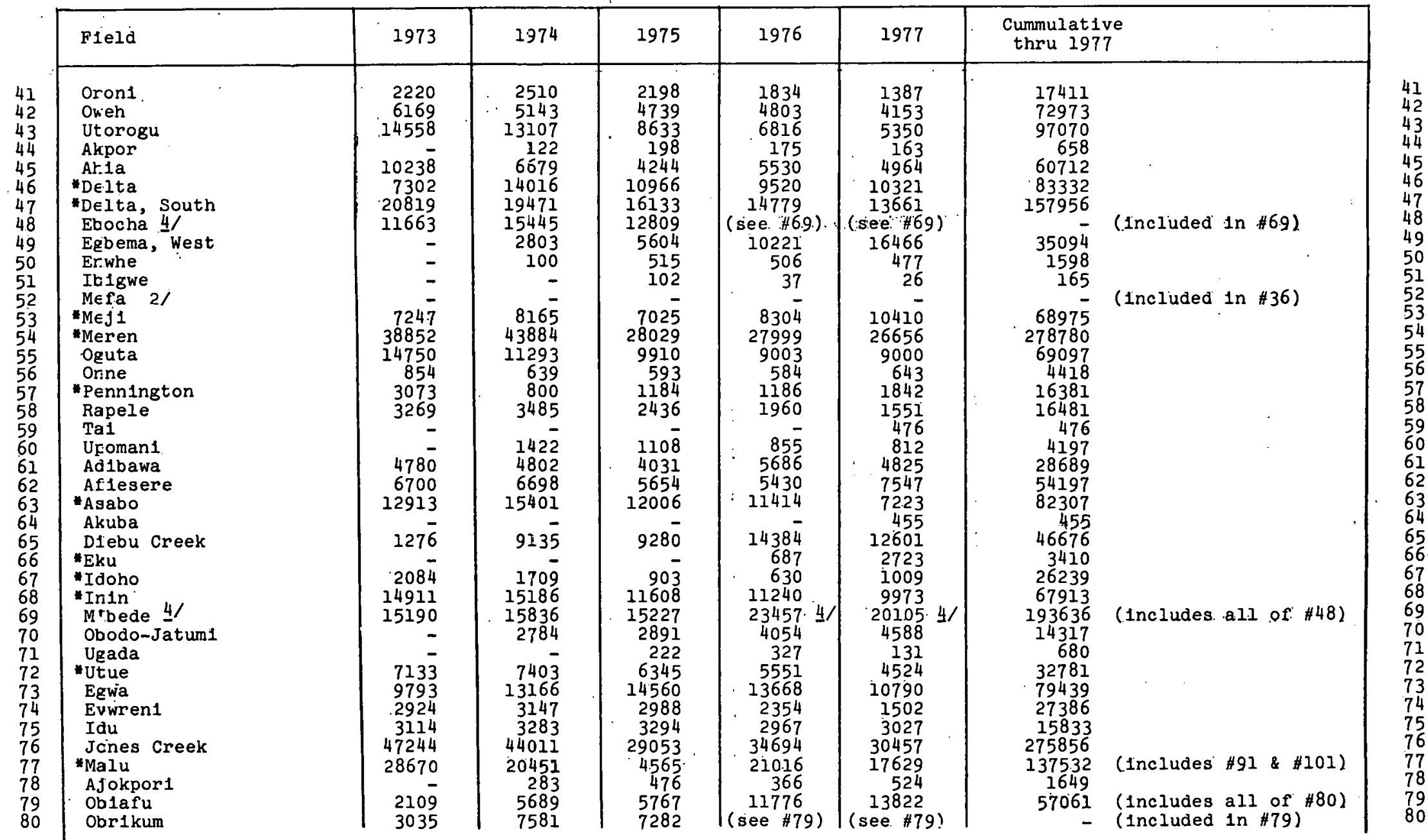

- Offshore field.

* Year of discovery. 
APPENDIX D

Historical Resume of o1l Field Production

(1000 barrels)

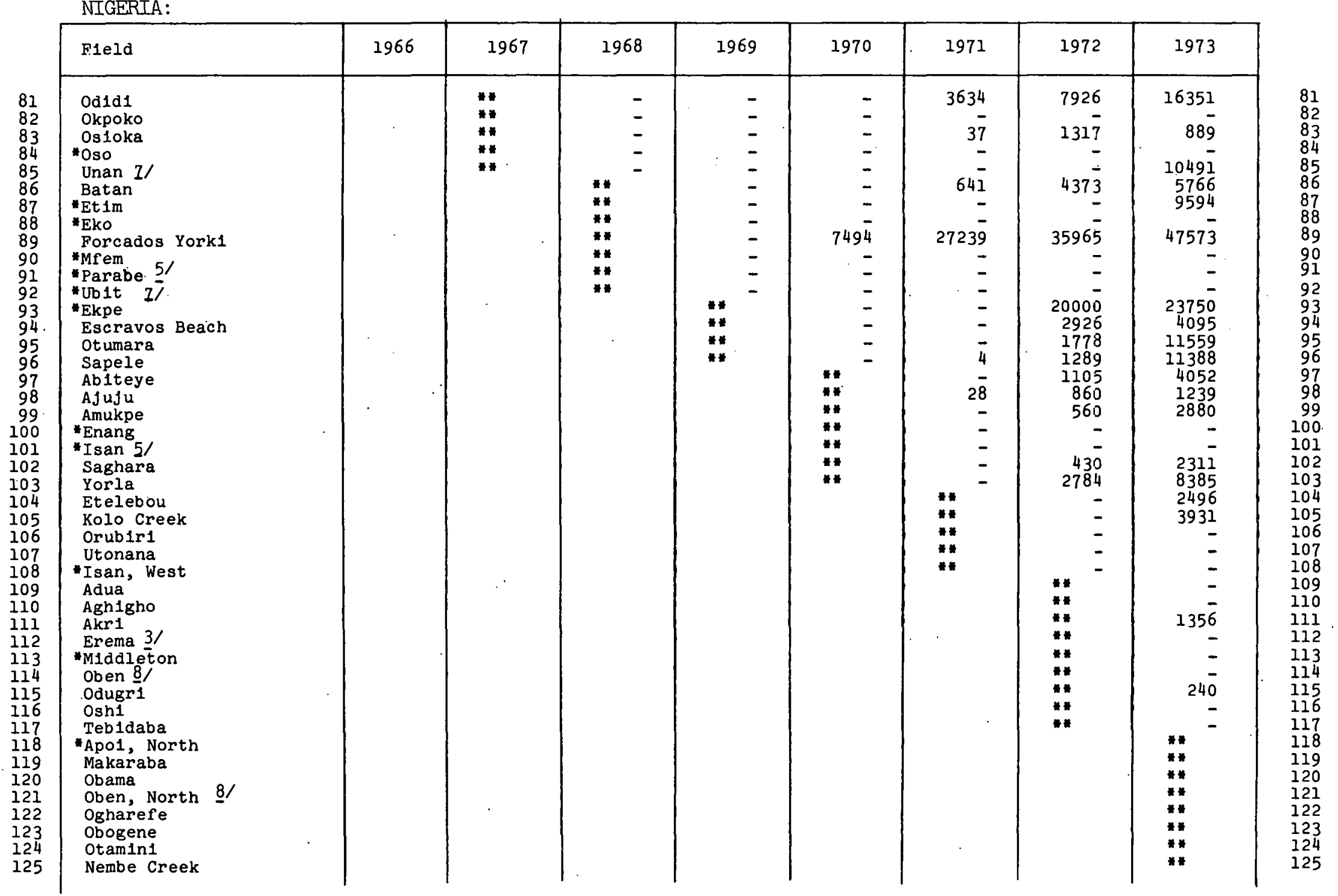


APPENDIX $\mathrm{D}$

H1storlcal Resume of 011 Fleld Production

(1000 barrels)

NIGERTA :

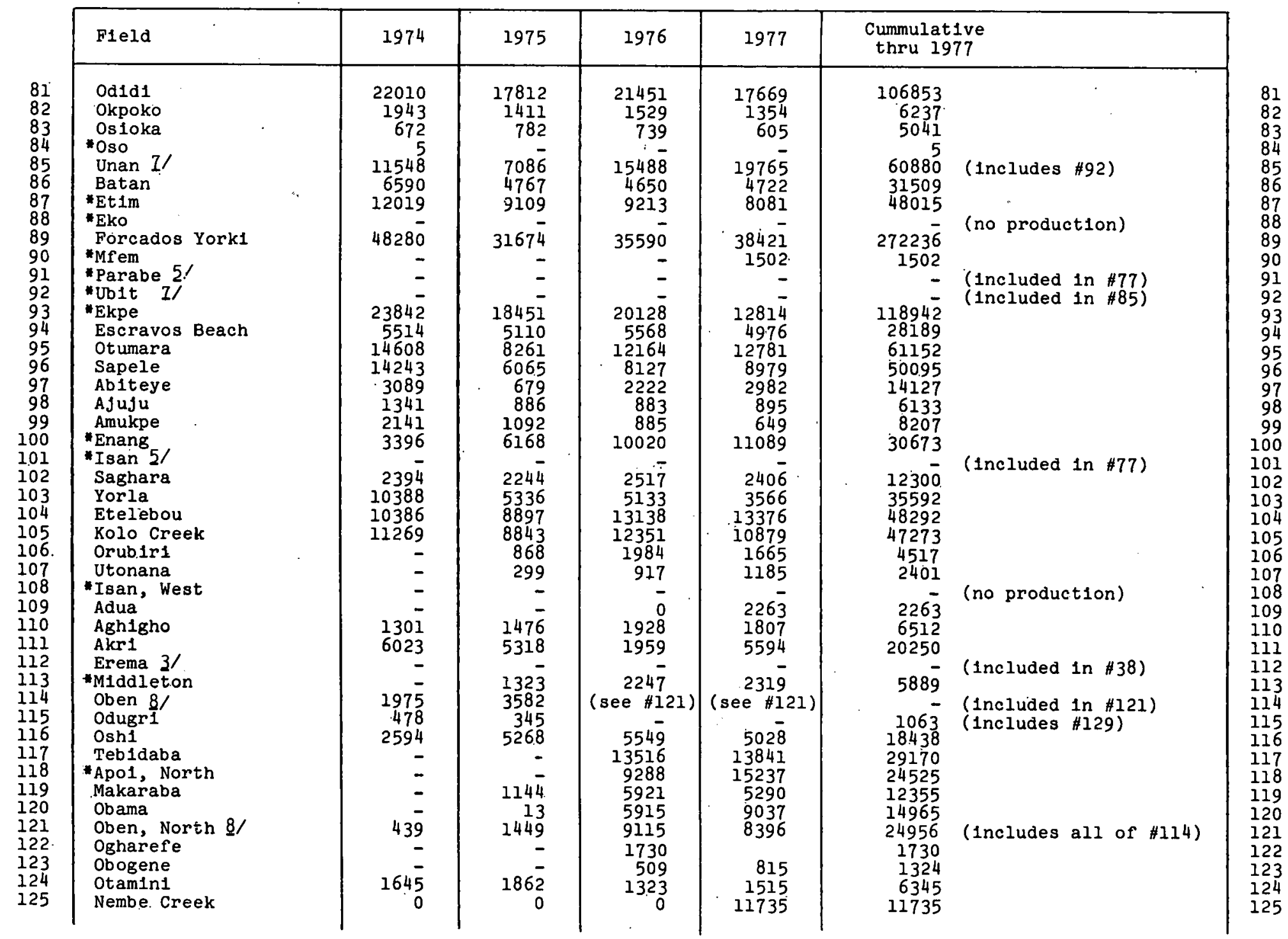


Page 8

APPENDIX D

H1storical Resume of 011 Field Production (1000 barrels)

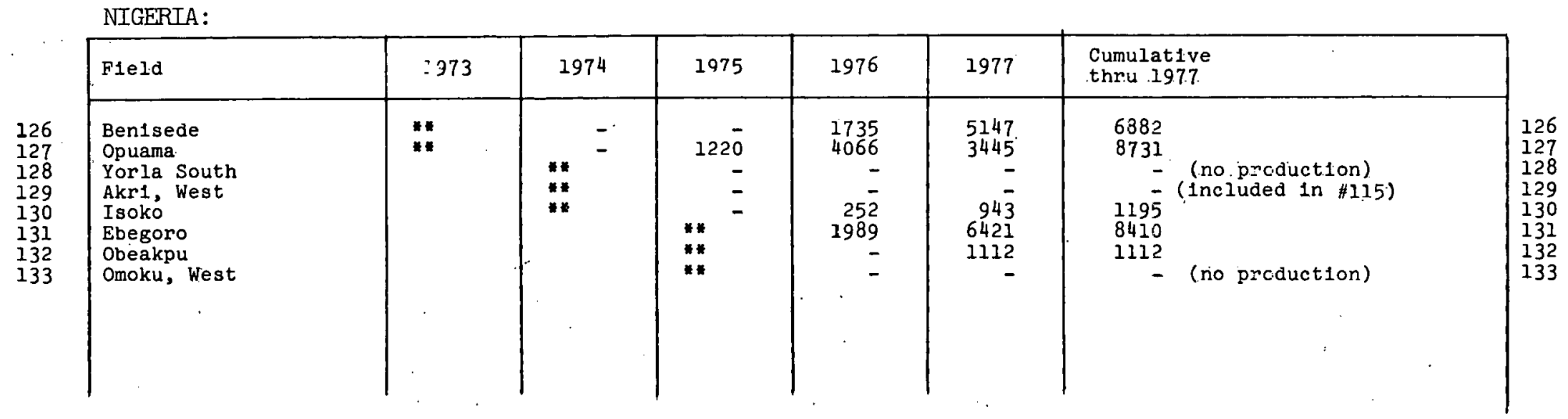

I/ Source: Petroconsultants; S.A., Geneva, Swtizerland.

* Offshore fielo.

2/ Production of Okan ( $\$ 36)$ and Mefa (\#52) flelds combined.

* Year of discovery.

3/ Production of Obag1:( $\# 38)$ and Erema (\#112) flelds combined.

4/ 1976 and 1977 production of Ebocha ( $\# 48$ ) and M'bede (\#69) fields comb1ned.

5/ Production of Malu ( $\# 77)$, Parabe (\#91) and Isan ( $\# 101$ ) fields combined.

6/ 1976 and 1977 production of Oblafu (\#79) and obrikum (\#80) flelds combined.

7/ Production of Unan ( $\$ 85)$ and Ubit (\#92) flelds combined.

8/ 1976 and 1977 production of oben (\#114) and Oben North (\#121) flelds combined. 
